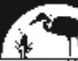

ILLINOIS

NATURAL

HIS TORY

SURVEY

\title{
Distribution, Abundance, and Habitat Associations of Franklin's Ground Squirrel (Spermophilus franklinii Sabine 1822)
}

\author{
J.J. Huebschman
}

Illinois Natural History Survey Bulletin

Volume 38, Article 1

February 2007 
Illinois Natural History Survey, David L. Thomas, Chief

A Division of the Illinois Department of Natural Resources

\author{
Illinois Natural History Survey \\ Distribution Office \\ I-Building \\ 1816 South Oak Street \\ Champaign, IL 61820
}

Citation:

Huebschman, J.J. 2007. Distribution, abundance, and habitat associations of Franklin's ground squirrel (Spermophilus franklinii Sabine 1822). Illinois Natural History Survey Bulletin 38(1):158.

Editor: Charles Warwick

\title{
US ISSN 0073-4918
}

Printed by authority of the State of Illinois

$\mathrm{P} 0122452-.75 \mathrm{M}-02-07$

Printed with soy ink on recycled and recyclable paper.

Equal opportunity to participate in programs of the Illinois Department of Natural Resources (IDNR) and those funded by the U.S. Fish and Wildlife Service and other agencies is available to all individuals regardless of race, sex, national origin, disability, age, religion, or other non-merit factors. If you believe you have been discriminated against, contact the funding source's civil rights office and/or the Equal Employment Opportunity Officer, IDNR, One Natural Resources Way, Springfield, IL 62702-1271; 217/785-0067; TTY 217/782-9175. 


\title{
Distribution, Abundance, and Habitat Associations of Franklin's Ground Squirrel (Spermophilus franklinii Sabine 1822)
}

\author{
J.J. Huebschman
}

Correspondence to:

\section{J.J. Huebschman}

262 Gardner Hall

Department of Biology

University of Wisconsin-Platteville

Platteville, WI 53818, USA

Phone: (608) 342-1742

Fax: (608) 342-1088

E-mail: huebschj@uwplatt.edu 


\section{CONTENTS}

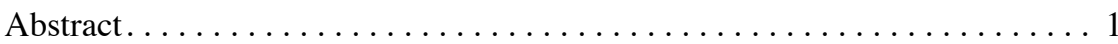

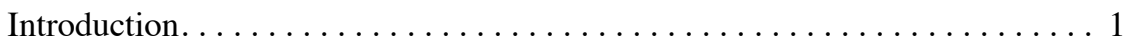

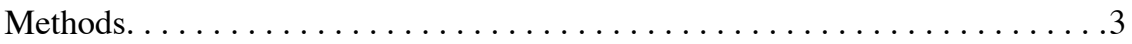

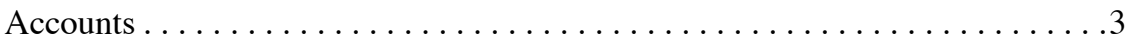

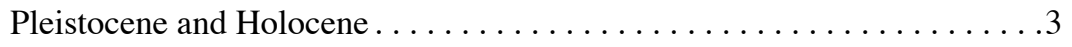

North America. ............................

Canada. ....................................5

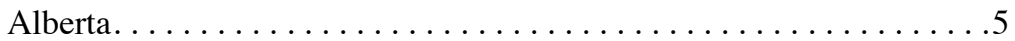

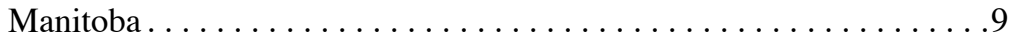

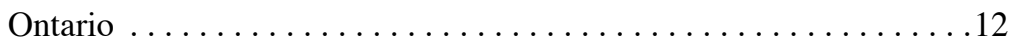

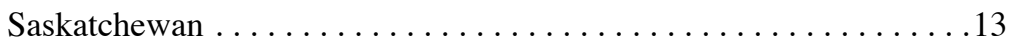

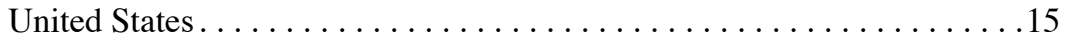

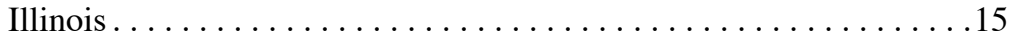

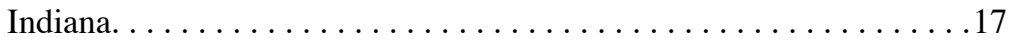

Iowa. . . . . . . . . . . . . . . . . . . . . . 18

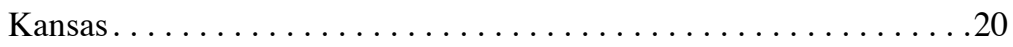

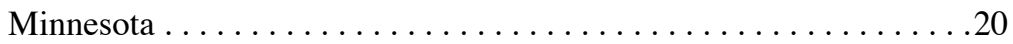

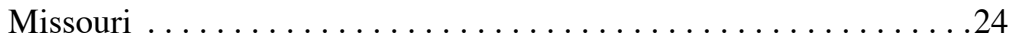

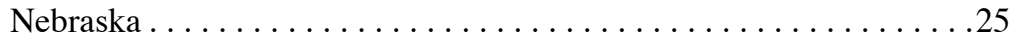

North Dakota. . . . . . . . . . . . . . . . . . . . . . . .26

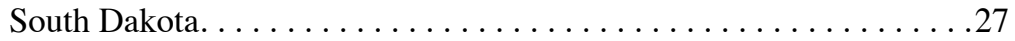

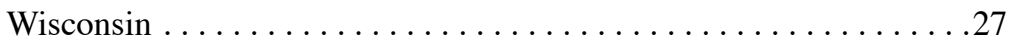

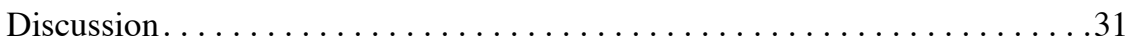

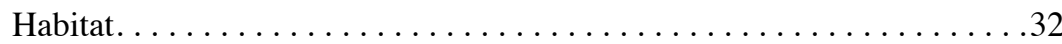

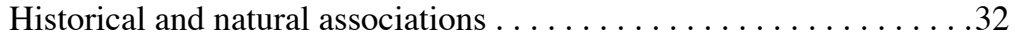

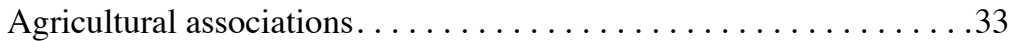

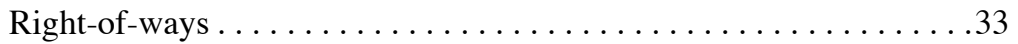

Influence on Abundance. ..................................

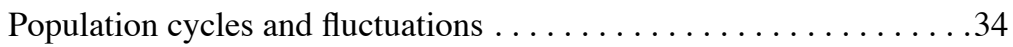

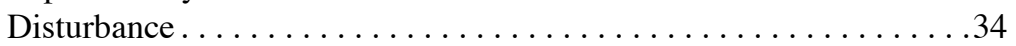

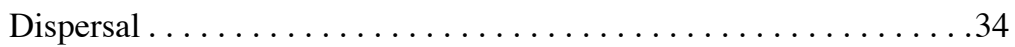

Effects of habitat.........................

Conservation and Threats ...........................

Habitat loss and disturbance ........................

Conservation status ...............................

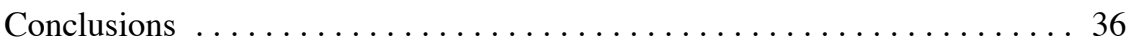

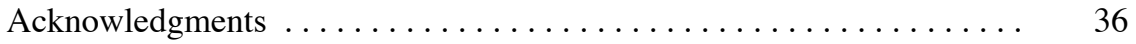

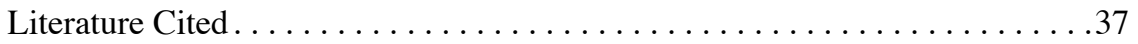

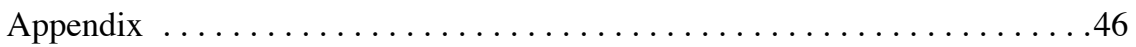




\section{ABSTRACT}

To better inform conservation and management strategies directed at Franklin's ground squirrel, Spermophilus franklinii, I reviewed published and unpublished accounts of the squirrel's distribution, abundance, and principally, habitat associations. I present the body of literature on $S$. franklinii and include portions of original accounts to avoid potential bias from paraphrasing. A consensus of the literature indicates that $S$. franklinii is most frequently associated with habitat characterized by a mixture of grassy and woody vegetation, referred to as savanna-like or parkland habitat. Moreover, $S$. franklinii has had an affinity for this type of habitat throughout its geographic range in recent, historic, and even prehistoric times. This is in contrast to a view of the species as primarily associated with tallgrass prairie habitat. As indicated in the literature, populations of $S$. franklinii are subject to marked fluctuations, which probably are influenced by local disturbances in addition to regular dispersal events. In the southern part of its geographic range, $S$. franklinii is currently limited in its occurrence principally to roadside and railroad rightof-ways. In these southern regions $S$. franklinii is justifiably of conservation concern. I suggest that more detailed surveys for the species (such as those that have recently occurred in Illinois and Missouri) take place in Iowa and Kansas.

Keywords: Franklin's ground squirrel, savanna, Spermophilus franklinii

\section{INTRODUCTION}

Franklin's ground squirrel, Spermophilus franklinii (Sabine 1822), is a large ground squirrel, tawny-brown in color, with the exception of both its head and fluffy tail, which are grayish (Fig. 1). The dorsal surface of the squirrel is finely mottled as a result of barring on the shafts of individual hairs that alternates between tawny-brown and black. Hair on the tail, which is long and soft, appears gray because of black and pale-gray barring. Like other North American ground squirrels, $S$. franklinii is both semi-fossorial and an obligate seasonal hibernator (Murie 1999). The annual cycle of $S$. franklinii follows a pattern characteristic of most species of ground squirrels. The ground squirrel cycle begins in spring with emergence from winter hibernacula, and follows with breeding, gestation, lactation, juvenile emergence from natal burrows, fattening prior to hibernation, autumn immergence into hibernacula, and hibernation until the following spring (Michener 1984). The geographic distribution of S. franklinii extends from northwest Indiana to north-central Kansas in the south and north through portions of Ontario, Manitoba, Saskatchewan, and Alberta (Fig. 2).

In recent years, interest in $S$. franklinii has increased because of reported declines in some populations (Jones 1964, Schwartz and Schwartz 1981, Johnson and Choromanski-
Norris 1992, Benedict et al. 1996, Pergams and Nyberg 2001, Martin et al. 2003). These declines largely have been reported from the southern, and particularly the southeastern, portion of the squirrel's geographic range. As a result of declining populations, $S$. franklinii warranted an account in the 2003 Red List produced by the World Conservation Union (IUCN), where it was listed as "Vulnerable" (Pergams and Nyberg 2003). Currently, $S$. franklinii also is listed as State-Endangered in Indiana (in writ., Indiana Department of Natural Resources Wildlife Diversity Section 2004), State-Threatened in Illinois (in writ., Illinois Endangered Species Protection Board 2004), and of Special Concern in Missouri (in writ., Missouri Natural Heritage Program 2005) and Wisconsin (in writ., Wisconsin Natural Heritage Working List, 2004).

According to Murie (1999), S. franklinii continues to be one of the least known of the North American ground squirrels. This fact is attributable, in part, to the squirrel's habit of occurring in areas of thick vegetation (Jones et al. 1983), which inhibits notice and observation of the animal-a fact that also contributes to the dual problem of accurately surveying for the animal and detecting declining populations. I first observed $S$. franklinii in small fragments of tallgrass prairie in eastern Nebraska and, after reviewing the most recent mammalian references for this region (Jones et al. 1983, 
Figure 1. Franklin's ground squirrel, Spermophilus franklinii. Photo courtesy of Jim Rathert, Missouri Department of Conservation.

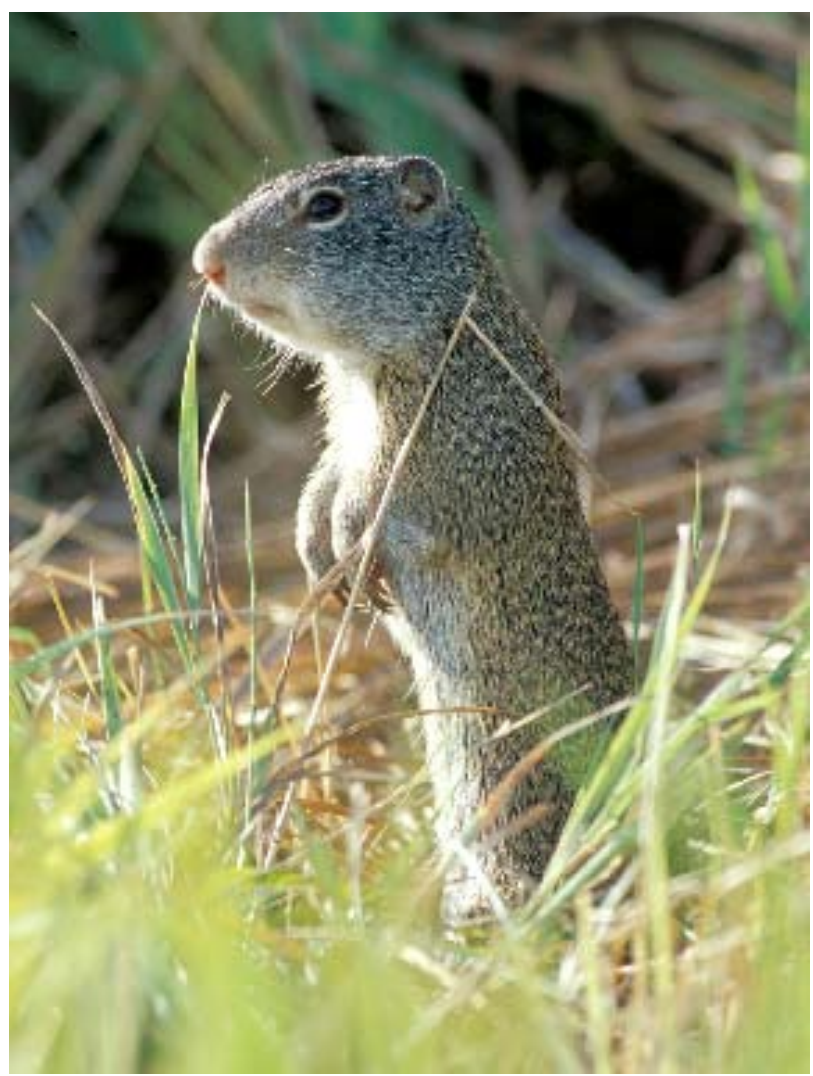

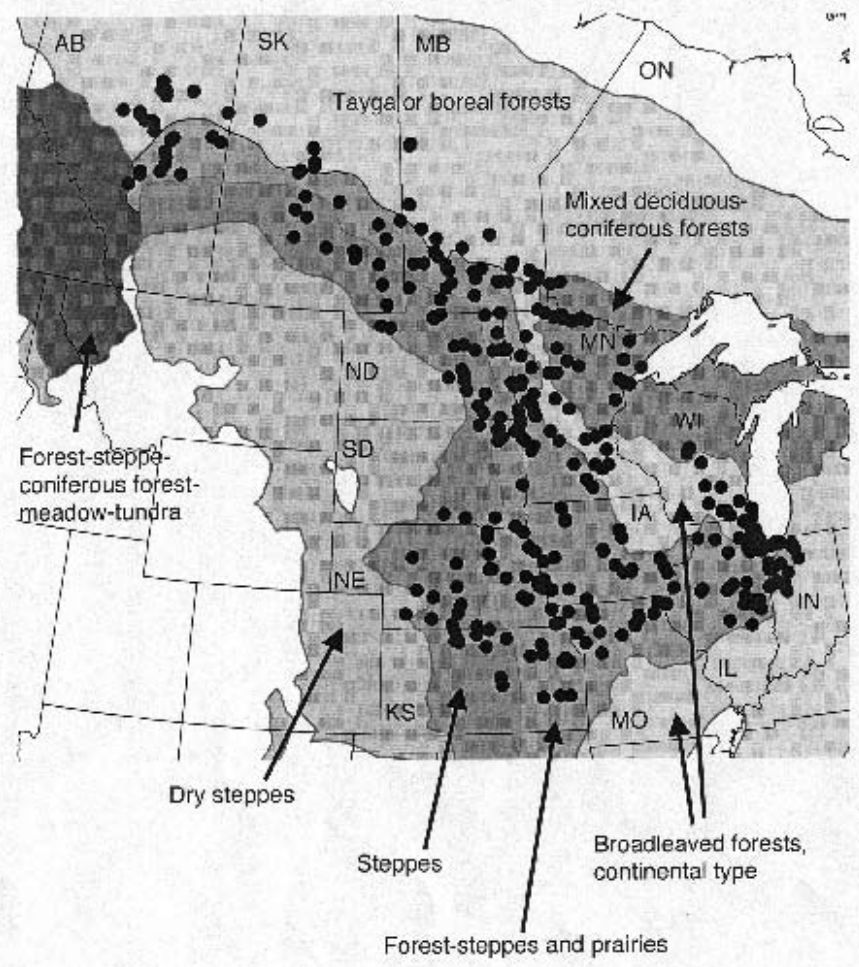

Figure 2. Geographic range map of $S$. franklinii based on a plot of capture localities for 732 museum specimens. The localities of museum specimens examined were converted into latitude and longitude coordinates, when not already given as such, by locating the collection sites on maps or in gazetteers. Bailey's (1998) ecoregion provinces for North America that occur within the geographic range of $S$. franklinii are labeled and overlaid on the map. States and provinces within the geographic range of $S$. franklinii are also labeled. Specimens examined are given in the Appendix. 
1985), believed $S$. franklinii to be restricted primarily to tallgrass prairie environments. Jones (1985, p. 157) stated, “A species of the tall-grass prairie, Franklin's ground squirrel must be much less abundant than it was prior to breaking the prairie for agriculture." My views of $S$. franklinii as a species closely associated with the tallgrass prairie did not change until I reviewed all available literature concerning the animal, which was widely scattered, often fragmentary, and in some cases, unpublished. In contrast to my initial views, the available literature suggests $S$. franklinii is an animal primarily of savanna-like habitats, that is, habitats with both a grassy and woody component. My experiences live-trapping $S$. franklinii throughout its geographic range confirm this conclusion. Admittedly, this revelation is largely personal, as persons sharing the squirrel's northern distribution have long considered $S$. franklinii a "brushland" species. However, the perception of $S$. franklinii as a mammal closely tied to prairie habitat remains prevalent in the most recent literature focused on the conservation of the species (Pergams and Nyberg 2003, NatureServe 2004).

Here I present the results of a comprehensive literature review I undertook on S. franklinii. I focus principally on the habitat associations of S. franklinii, and secondarily on geographic distribution and abundance. Comments summarizing these facets of $S$. franklinii biology and their relevance to the conservation issues surrounding $S$. franklinii are presented in the "Discussion" section.

One purpose of this review is to provide a complete and readily accessible source of information on S. franklinii for wildlife biologists, regional land-managers, and others engaged in making decisions that may affect the conservation and management of the species. In addition to practical management applications that may be garnered from this review, it also is my hope that further work on $S$. franklinii will be conducted in order to fill in regional gaps in knowledge about this species; surveys to document extant populations of $S$. franklinii in Iowa, Kansas, southern Minnesota, and South Dakota are a place to start. Finally, I hope this review will inspire much-needed basic ecological research on $S$. franklinii. For example, what factors limit the squirrel's geographic range? How are habitat components actually utilized and what factors are responsible for population fluctuations? In the next few decades it should no longer be said that $S$. franklinii remains one of the least known of North American ground squirrels.

\section{METHODS}

I reviewed both published and unpublished materials. Unpublished materials included early reports of U.S. Biological Survey field personnel archived in the Smithsonian's National Museum of Natural History (NMNH). All archived sources are from Series 1 and 2 of Record Unit 7176, United States Fish and Wildlife Service, Field Reports from 18601961. I provide box and folder numbers for all individual references obtained from $\mathrm{NMNH}$ archived sources. Unpublished material also included state and federal reports, graduate theses, and information on museum specimen tags. Patterns of distribution, abundance, and habitat association of $S$. franklinii were reviewed by state and province in a chronological fashion from the oldest records to the most recent, in order to facilitate ease in finding information on a specific region. An account of $S$. franklinii from the late Pleistocene and Holocene was also included. Portions of original accounts were included throughout this review in order to avoid potential bias from paraphrasing.

\section{ACCOUNTS}

\section{Pleistocene and Holocene}

Eshelman and Hibbard (1981) tentatively reported S. franklinii from the Nash local fauna in Meade County, Kansas, on the basis of two teeth. Their site is bracketed between two layers of volcanic ash dated at 1.2 and 1.9 million years before present (YBP). Evidence suggests that this site was characterized by semiarid prairie with cool habitat along a stream (Eshelman and Hibbard 1981). If accurately identified, the material from the Nash local fauna would represent the oldest records of $S$. franklinii of which I am aware.

The southernmost records of $S$. franklinii fossil material come from sites in northern Texas. Griffin (1989) reported S. franklinii from the Patterson Ranch local fauna in Knox County, Texas - a site from the middle of the Pleistocene Epoch dated at 600,000 YBP. Hibbard and Dalquest (1966) tentatively reported S. franklinii from the Vera local fauna, Knox 
County, Texas - a site contemporaneous with the Patterson Ranch local fauna. Hibbard and Dalquest (1966) described the climate of the paleo-environment at their site as moist, subhumid, and frost-free.

Rhodes and Semken (1986) reported $S$. franklinii from sites in Mills County, Iowa, during the Wisconsinan, towards the end of the Pleistocene (Table 1). They described the late-Pleistocene habitat of this region of Iowa by stating, "Structurally, the vegetation probably was a parkland like that found today near the forest border in southern Manitoba and Saskatchewan" (Rhodes and Semken 1986, p. 109). They later continued (p. 123), "The Wisconsinan fauna best represents a mosaic of boreal hardwoods and conifers distributed in an open, meadowlike grassland or parkland during much of the glacial period."

Slaughter and Hoover (1963) documented that S. franklinii still occurred as far south as northeastern Texas, approximately $650 \mathrm{~km}$ south of its current southern limit, during the late Pleistocene. They recorded it in the Ben Franklin local fauna, a site dated at approximately 9,000 - 11,000 YBP in Delta County, Texas (Slaughter and Hoover 1963). The paleo-environment of the site was characterized by numerous large marshes that bordered shallow streams of cool water (Slaughter and Hoover 1963). The most southwestern location of $S$. franklinii, from Beaver County in the Oklahoma Panhandle, also was recorded from a late Pleistocene site (Dalquest and Baskin 1992). According to Dalquest and Baskin (1992) the Elm Creek Site where S. franklinii was found "may have offered concealing cover bordering the zone of riparian woodland marginal to the stream" (p. 16). The Elm Creek Site was dated at approximately 11,000 YBP (Dalquest and Baskin 1992).

Although represented in the late Pleistocene, occurrence of $S$. franklinii in the fossil record increased during the Holocene (Table 1), principally in the lower Midwest. In most cases, $S$. franklinii material was associated with habitat consisting of woodland edges and openings (Purdue and Styles 1987) or occasionally riparian woodlands along glacial streams (Dalquest and Baskins 1992).

Within the last 1,000 - 1,500 YBP, S. franklinii has been found in association with human settlements. At the Phipps and Brewster cultural sites in western Iowa, Rhodes and Semken (1986) noted a high incidence of the plains pocket gopher, Geomys bursarius, along with both the thirteen-lined ground squirrel, $S$. tridecemlineatus, and $S$. franklinii. These species "could have been systematically harvested both for subsistence and in an attempt to mitigate their impact on garden plots" (Rhodes and Semken 1986, p. 117).

\section{North America}

Coues and Allen (1877) provided comments on S. franklinii that pertained to the species throughout its entire geographic range in North American (Fig. 2). Unfortunately, much of the geographic information they presented was not accurate (see information in the Missouri account). However, their account does provide insight into the historic habitat associations of S. franklinii. They stated that it "has a greater preference for thickets, low bushes and borders of timber" than S. tridecemlineatus (Coues and Allen 1877, p. 883). They also stated "though a common animal of the prairies of northern Illinois and Wisconsin, it was unknown even to Audubon and Bachman, as late as 1851" (Coues and Allen 1877, p. 882). More recently, Hall and Kelson (1959) quite succinctly stated that $S$. franklinii "occurs in areas of dense high (10 inches or more) grass or weedy vegetational cover and not on closely grazed or mowed fields" (p. 351). Murie (1999) provided an excellent summary account of the species for North America. He noted that they are found in "tall grass in disturbed areas, shrubland, and woodland edges" (p. 419) and that they are sporadically distributed, usually in small colonies, but occasionally with larger populations occurring near marshlands.

In recent reports focused on the conservation status of $S$. franklinii in North America, the species was listed as "Vulnerable" (Pergams and Nyberg 2003) and "Secure" (NatureServe 2004). (The NatureServe assessment of $S$. franklinii was last reviewed in 1996 (NatureServe 2004), prior to the evaluation done by Pergams and Nyberg (2003).) The assessment of Pergams and Nyberg (2003) "is based on declines in area of occupancy and extent of occurrence of S. franklinii of $>30 \%$ over both the past 10 years, and projections that these declines will continue over the next 10 years. Note is also taken of the extent of loss of the primary habitat of $S$. franklinii: tall- and midgrass prairie" ("Justification" section of Web document). The authors of the Nature- 
Serve document state of $S$. franklinii's habitat use: "Has a strong affinity for tallgrass prairies and the 'edge' between open areas and weeds. Also uses riparian areas (marsh edges), fields, and hedgerows. Generally avoids shortgrass habitats" ("Ecology and Life History" section of Web document). Those authors also suggest that the geographic range of S. franklinii may presently be larger than in historic times but likely is occupied by an overall smaller population (NatureServe 2004). Pergams and Nyberg based their ranking, in part, on results from a telephone/e-mail survey of state and provincial mammalogists in which they asked questions concerning the status of $S$. franklinii in their regions.

\section{Canada}

Sowls (1948) provided a general review of $S$. franklinii in Canada, where the species reaches the northern limit of its geographic distribution (Fig. 2), from his own observations and those of others, particularly J. Dewey Soper. In an unpublished manuscript cited by Sowls and written by Soper in 1941 (that I could not locate), Soper stated that $S$. franklinii was "essentially an animal of the Transition Zone of the aspen parklands found between the treeless plains and the Canadian Zone forest" (in Sowls 1948 , p. 115). Soper also stated that in southern Manitoba and northwest of that region, $S$. franklinii inhabited "the aspen poplar groves of the prairie, as well as the wooded lake ridges and the stream and marshland borders" but was "absent from the treeless and scrubless areas" (in Sowls 1948, p. 115).

More recently Banfield (1974) reiterated these earlier observations when he summarized the ecology of $S$. franklinii in Canada. He stated: "Franklin's ground squirrels inhabit wooded areas and the edges of woods. They are abundant in poplar bluffs of the aspen parkland that lies between the Great Plains and the coniferous forest. They have even penetrated the coniferous forest belt along the alder banks of streams and the patches of poplars in the evergreen forests, and frequently hunt in marshy areas that lie close to wooded ridges" (Banfield 1974, p. 126). Banfield (1974) stated that populations of the species fluctuate dramatically and average populations in good habitat range from 1.6 to 2.1 animals per hectare.
Alberta. Franklin's ground squirrel reaches the northwest limits of its geographic range in Alberta (Fig. 2). Records indicate that in Alberta $S$. franklinii has been associated most commonly with aspen parkland habitat where it ranges from locally abundant to absent (Table 2 ). In addition to the accounts cited in Table 2 , other sources supplement the current knowledge of S. franklinii in Alberta. The earliest account of the species from the province known to me comes from J. Alden Loring from 1894. Loring's account (in lit., NMNH archives, Box 117, Folder 5) from September of that year from "South Edmonton" stated, "A single specimen was taken a short distance from town" and "They are said not to be very common."

During the 1960s and to a greater extent the 1970s, several publications appeared that tangentially referenced the occurrence of $S$. franklinii in Alberta. These included publications on the food habits of raptorial birds (Meslow and Keith 1966, McInvaille and Keith 1974) and on the parasites of ground squirrels (Hilton and Mahrt 1971, 1972; Tobon et al. 1976). For the purpose of this review, these studies simply provide evidence of the occurrence of S. franklinii in Alberta at a particular place and time. Three of these studies indicated the presence of $S$. franklinii in the vicinity of Rochester, which is about $96 \mathrm{~km}$ north of Edmonton (Meslow and Keith 1966, McInvaille and Keith 1974, Tobon et al. 1976). Hilton and Mahrt collected $S$. franklinii from the Innisfree area (Hilton and Mahrt 1971) and from four sites in central Alberta (for which they provided a map only with no specific locations); three sites were located between Edmonton and the Saskatchewan border, and one was located roughly between Edmonton and Calgary (Hilton and Mahrt 1972).

Keith and Cary (1991) reported on population trends of $S$. franklinii that they observed coincident with a study on population cycles of snowshoe hare, Lepus americanus, conducted in the Rochester area during 1965-1975. They set unbaited traps along L. americanus runways in blocks of primarily aspen (Populus tremuloides) forest (Keith and Meslow 1966). During the course of their study, 236 S. franklinii were captured as incidental species. The primary incidental capture among mammalian species was the red squirrel, Tamiasciurus hudsonicus, which was caught 1,820 times (Keith and Cary 1991), further indicating the wooded nature of Continued on page 9 
Table 1. Late Pleistocene (until 13,000 YBP) and Holocene (13,000 YBP to current time) sites from the Midwest where Franklin's ground squirrel, Spermophilus franklinii, material was recovered. Descriptions of the hypothesized habitat at the site are included when available.

\begin{tabular}{llll}
\hline Site name & Location & $\begin{array}{l}\text { Estimated time } \\
\text { period (YBP) }\end{array}$ & Hypothesized habitat \\
\hline
\end{tabular}

Craigmile Mills Co., IA

Waubonsie Mills Co., IA

Kimmswick Jefferson Co, MO

Elm Creek Beaver Co., OK

$11,410+/-410$

Modoc Randolph Co., IL

Rock

Shelter

Dows

Franklin Co., IA

$9380+/-130$

Cherokee

Cherokee Co., IA

6,350

Sewer site,

Horizon I

Coffey

$12,000-11,000$

$10,000-8,500$
$23,240+/-535$

$14,800+/-1000$

"The high relative frequency of meadow and grassland ecotypes indicates that extensive boreal grasslands, primarily moist meadows, dominated the landscape. The remaining taxa show that mixed groves of deciduous and coniferous trees with their brushy margins persisted on favorable exposures and provided a weak mosaic of boreal and cool/mesic habitats" (p. 108).

Boreal grasslands with increased brushland and forest edge.

Cultural site. Species indicate a mix of open and closed, forested habitat.

Purdue and Styles 1987

"The Elm Creek Site may have offered Dalquest and Baskin 1992 concealing cover bordering the zone of riparian woodland marginal to the stream" (p. 16).

Some species indicative of open habitat, but the majority are associated with forest or forest edge.

Cool, moist, open deciduous forest with more effective precipitation than today.

Upland prairie with a gallery forest along major watercourses.

Most species at site associated with eastern forests. Floodplain forests present, attested to by Celtis sp. (hackberry), Fraxinus sp. (ash), Ulmus sp. (elm), Acer sp. (maple or boxelder), Populus sp. (cottonwood), and Salix sp. (willow). Upland forest was reduced and replaced with short or mixed-grass vegetation.

Semken and Falk 1987

Purdue and Styles 1987

Rhodes and Semken 1986

Davis 1987
Rainbow site, Plymouth Co., IA

cultural

horizons $\mathrm{A} \& \mathrm{C}$,
$\mathrm{A}=1760-1695$

$\mathrm{C}=1410-1350$

For both time periods habitat consisted Rhodes and Semken 1986 of woodlands, stream, stream-edge and grassland characterized as tallgrass parkland. 
Table 1 contiued

\begin{tabular}{|c|c|c|c|c|}
\hline Site name & Location & $\begin{array}{l}\text { Estimated time } \\
\text { period (YBP) }\end{array}$ & Hypothesized habitat & Reference \\
\hline $\begin{array}{l}\text { Oakwood } \\
\text { Lakes }\end{array}$ & Brookings Co., SD & $1650-1050$ & $\begin{array}{l}\text { A long-term woodland occupation. } \\
\text { Grassland association. }\end{array}$ & Semken and Falk 1987 \\
\hline $\begin{array}{l}\text { Pleasant } \\
\text { Ridge }\end{array}$ & Mills Co., IA & $1450+/-90$ & $\begin{array}{l}\text { More arid than modern Missouri } \\
\text { Valley. }\end{array}$ & Rhodes and Semken 1986 \\
\hline Phipps & Cherokee Co., IA & $1140-600$ & $\begin{array}{l}\text { Complex, multicomponent village. } \\
\text { Mesic. }\end{array}$ & Rhodes and Semken 1986 \\
\hline Brewster & Cherokee Co., IA & $1025-750$ & $\begin{array}{l}\text { Gallery forest, prairie, marsh, } \\
\text { permanent water. Cultural site. }\end{array}$ & Rhodes and Semken 1986 \\
\hline Wittrock & O'Brien Co., IA & $980-525$ & Floodplain village. & Rhodes and Semken 1986 \\
\hline Chan-ya-ta & Buena Vista Co., IA & 900 & Prairie association. & Rhodes and Semken 1986 \\
\hline $\begin{array}{l}\text { Solomon } \\
\text { River }\end{array}$ & Mitchell Co., KS & $860+/-80$ & $\begin{array}{l}\text { Small farming hamlet in a mesic } \\
\text { grassland setting. }\end{array}$ & Davis 1987 \\
\hline
\end{tabular}

14ML15

Glenwood Mills Co., IA

852-698 Village and nonvillage. "A cool,

Rhodes and Semken 1986 damp environment, which supported both meadows and forests, was present on the floodplains; valley slopes were characterized by well-drained woodlands which graded upslope into a shrubby zone and finally into an upland prairie" (p. 120).

\begin{tabular}{llcll} 
Bill Packer & Sherman Co., NE & $850-750$ & Similar to following account. & Semken and Falk 1987 \\
Schmidt & Howard Co., NE & $830-790$ & $\begin{array}{l}\text { Central Plains Tradition earth lodge } \\
\text { village. "The Schmidt l.f. is most } \\
\text { representative of a riverine community } \\
\text { with an open gallery forest/meadow } \\
\text { association along the flood plain, } \\
\text { bordered by a tall-grass prairie on the } \\
\text { slopes and a shorter-grass prairie on the } \\
\text { uplands" (p. 209). }\end{array}$ & Semken and Falk 1987 \\
Cahokia & St. Clair Co., IL & $800-400$ & Information not available. & Purdue and Styles 1987 \\
Milford & Dickinson Co., IA & 250 & Information not available. & Rhodes and Semken 1986 \\
\hline
\end{tabular}


Table 2. Notes on Franklin's ground squirrel, Spermophilus franklinii, in Alberta.

\begin{tabular}{|c|c|c|c|}
\hline Locality & Habitat & Abundance & Citation \\
\hline Edmonton area & $\begin{array}{l}\text { "They frequented brushy tracts and } \\
\text { the borders of cultivated fields" (p. 165). }\end{array}$ & $\begin{array}{l}\text { "It is abundant along the road } \\
\text { from a few miles north of Edmonton, } \\
\text { Alberta to Sturgeon River" (p. 165). }\end{array}$ & Preble 1908 \\
\hline Alberta general & $\begin{array}{l}\text { "we had a glimpse of a Franklin's ground } \\
\text { squirrel as it scampered into an aspen } \\
\text { bluff beside the trail" (p. 103) } \\
\text { "several sources indicated that it was } \\
\text { more likely to occur on the brushy wet } \\
\text { slopes of Pleasant Valley than anywhere } \\
\text { else" (p. 107) } \\
\text { "I had also reports of its occurrence in } \\
\text { the region of Raft Lake, where it visits } \\
\text { the portable graineries drawn up near } \\
\text { the woods" (p. 107). }\end{array}$ & "at Isaly is nearly absent" (p. 106). & Soper 1921 \\
\hline Alberta general & $\begin{array}{l}\text { "The more common tracts of occupation } \\
\text { are located in poplar 'bluffs' and shrubby } \\
\text { grasslands of scattered prairies in park- } \\
\text { lands of the Transition Zone. It also } \\
\text { invades grassy forest glades, borders } \\
\text { of fields and meadows, dry marshes } \\
\text { and sloughs, roadsides and railway } \\
\text { tracks" (p. 142). }\end{array}$ & $\begin{array}{l}\text { "In some parts of Alberta they are } \\
\text { tolerably common, but local dispersal } \\
\text { is often spotty with noticeable } \\
\text { scarcity, or apparent absence, in } \\
\text { different localities" (p. 143). } \\
\text { "The species appears to be slowly } \\
\text { extending its range west and north with } \\
\text { the expansion of settlement" (p. 142). }\end{array}$ & Soper 1964 \\
\hline $\begin{array}{l}\text { Miquelon Lake } \\
\text { Park Prov. }\end{array}$ & $\begin{array}{l}\text { area around the garbage pit, surrounded } \\
\text { by aspen woodland habitat }\end{array}$ & $\begin{array}{l}\text { "Density of adults varied between } 1.25 \\
\text { and } 2.50 \text { per ha ( } 0.4 \text { to } 0.8 \text { per acre)" } \\
\text { (p. 337). }\end{array}$ & Murie 1973 \\
\hline Alberta general & $\begin{array}{l}\text { "aspen parkland belt, especially along } \\
\text { the forest edge, where there may be } \\
\text { dense grasses" (p. 88). }\end{array}$ & $\begin{array}{l}\text { "It is considered uncommon here } \\
\text { but the status is difficult to determine. } \\
\text { It may be numerous in some areas...it is } \\
\text { not a conspicuous member of the mammal } \\
\text { community" (p. 88). }\end{array}$ & Smith 1993 \\
\hline
\end{tabular}


the study site. Keith and Cary (1991) showed clear fluctuations in the capture rate of $S$. franklinii during their study period, including a time when the population fell "precipitously" (p. 375). The sharp decline in the S. franklinii population was roughly coincident with declines in both T. hudsonicus and the northern flying squirrel, Glaucomys sabrinus, populations. Keith and Cary (1991) reported speculation (from Erlien and Tester 1984- see the Minnesota account) that these declines, which occurred after L. americanus declines, may have been the result of prey-switching behavior by predators of L. americanus.

Sargeant et al. (1993) conducted a study on predators that affect duck production in the Prairie Pothole region, which includes a small portion of Alberta. Throughout this review, I refer to their results as they pertain to $S$. franklinii, which are summarized in Table 3. Their data primarily reflect the occurrence of $S$. franklinii in a particular region with some information on relative abundance (see Table 3). The authors do not provide specific information on habitat use but, instead, present an overview of the physiographic characteristics of all of their study sites. Most (21 of 33) of their study sites occurred in the prairie zone within the Prairie Pothole region, with the remainder (12 of 33) falling within the aspen parkland zone (Sargeant et al. 1993). Sites were composed of croplands (average coverage 54\%), grasslands $(25 \%)$, wetlands (13\%), woodlands (3\%), and additional odd areas or barrens (5\%) (Sargeant et al. 1993). Cultivated areas included small grains, sunflower, corn, and other row crops (Sargeant et al. 1993). Grassland areas usually were grazed by livestock, and most study areas included occupied or abandoned farmsteads (Sargeant et al. 1993). Trees were found in each study area but were most numerous in areas within the aspen parkland zone, where quaking aspen trees ( $P$. tremuloides), with hazelnut (Corylus sp.) or willow (Salix spp.) understory, were prevalent around wetlands and in small woodlots (Sargeant et al. 1993). Within the prairie zone, trees were usually in single-row shelterbelts in fields or in multirow windbreaks at farmsteads (Sargeant et al. 1993).

In 1983 Sargeant et al. (1993) found $S$. franklinii in Alberta at their Holden and Hay Lakes study sites, both of which were in the aspen parkland zone (Table 3). Relative to other sites in their study (which were located throughout the Prairie Pothole region), at these locales S. franklinii was ranked as "scarce" (Sargeant et al. 1993, Table 3). Both sites contained woodlots up to $0.65 \mathrm{~km}^{2}$ (Sargeant $e t$ al. 1993).

Manitoba. Franklin's ground squirrel has been documented in Manitoba (Fig. 1) since at least 1882 (Seton 1910). It often has been referred to as a common or plentiful species (Bird 1927; Green 1932; Soper 1946, 1961a). However, as Sowls (1948) stated, local populations tend to be variable in size over time (see also Table 4). When present, S. franklinii occurs at the interface of woodlands and grasslands where there is often an ecotone composed of various shrubby species (Table 4). In areas of pure grassland, the species is usually limited to isolated patches of woody habitat.

J.A. McLeod (1933) conducted a survey of parasites found in species of Spermophilus (then Citellus) within Manitoba. Although he provided a thorough review of the parasites, he included virtually no information on the hosts, with one notable exception. For the three species of squirrels he examined (S. tridecemlineauts, S. franklinii, and $S$. richardsonii), he reported years of peak abundance based on observations of farmers and naturalists within the province. For S. franklinii, years of peak abundance occurred in 1912, 1917, 1923, 1927, and 1932 (McLeod 1933). McLeod (1933) also reported that squirrel populations experienced sharp declines between years of peak abundance.

Sowls' (1948) study of S. franklinii at Delta Marsh in Manitoba remains one of the most thorough to date. He found S. franklinii primarily on a wooded ridge bordering a lake and in small, isolated, tree-covered islands set in stands of reeds, Phragmites communis; occasionally, they were found in pure stands of these reeds (Sowls 1948). He reported extreme population fluctuations of $S$. franklinii at Delta Marsh. In 1938, a year of peak abundance, he reported "two boys with .22 rifles were able to kill fourteen in less than an hour without moving from one spot. Such numbers have not been observed since" (Sowls 1948, p. 115). Sowls (1948) wrote that between 1939 and 1942 an observer could see "about six per mile along the ridge road" (p. 115). However, by 1943 they were so uncommon at Delta Marsh Continued on page 12 


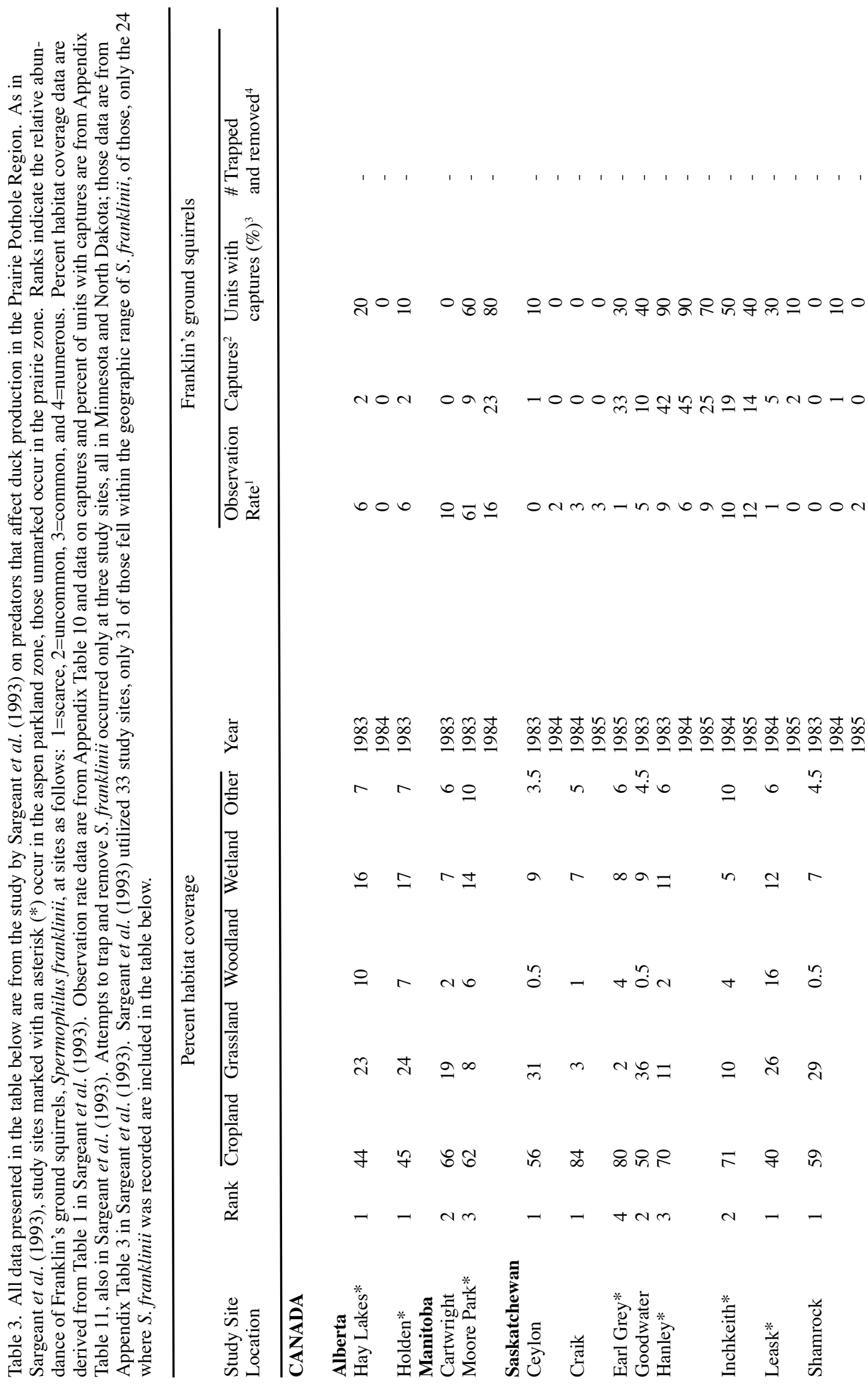




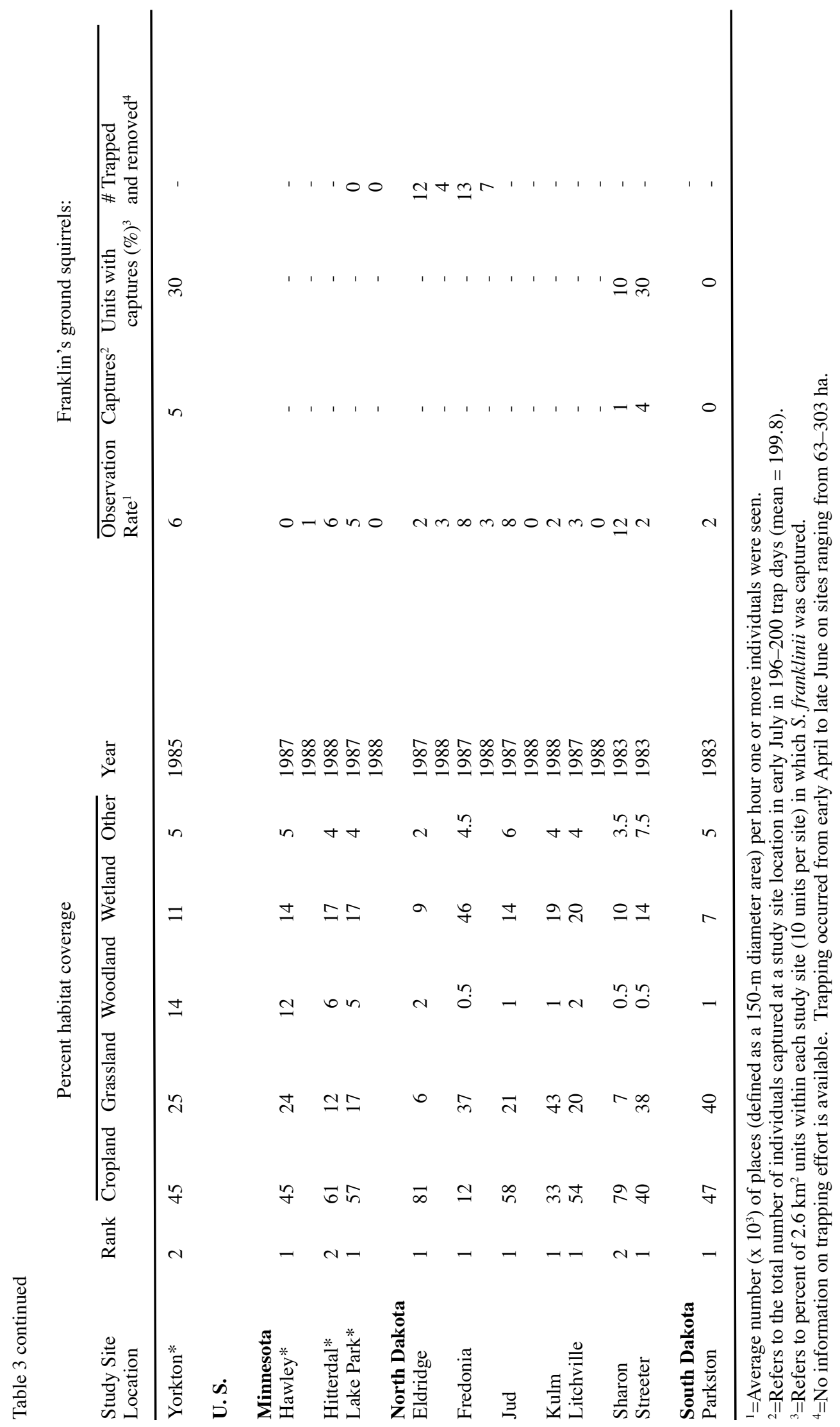


that a colleague of Sowls' claimed to have seen fewer than a dozen during the course of the summer and in1946 Sowls, himself, recorded fewer than two dozen squirrels during the entire summer.

Iverson and Turner (1972) studied S. franklinii at the Whiteshell Nuclear Research Establishment (located approximately $120 \mathrm{~km}$ northeast of Winnipeg). Their study population occupied disturbed patches in an old field that was bordered on two sides by aspen forest (Iverson and Turner 1972). Lynch (1972), whose study at Delta Marsh included S. franklinii in a suite of predators of duck nests, did not include specific information on the habitat use by the speciesalthough it may be inferred from other accounts of S. franklinii from the region (Sowls 1948; Tamsitt 1962). He did provide estimates of density for 1966, stating that $S$. franklinii ranged from 0.69 to 0.93 individuals per hectare (Lynch 1972). Wrigley (1974) found S. franklinii to be rare in his study area in the sandhills regions of southwestern Manitoba near Oak Lake and Margaret. Of those $S$. franklinii trapped, three were found by a small maple tree (Acer sp.) in an area composed largely of silverberry (Elaeagnus commutata) and snowberry shrubs (Symphoricarpos occidentalis), and two were found in an area of Saskatoon shrubs (Amelanchier alnifolia) (Wrigley 1974).

Two studies on parasites that occurred at Birds Hill Provincial Park in south-central Manitoba provide additional information on habitat associations and abundance of $S$. franklinii in Manitoba (Burachynsky and Galloway 1985, Reichardt and Galloway 1994). Burachynsky and Galloway (1985) caught greater numbers of $S$. franklinii in a study plot composed principally of grasses and shrubs (which were up to $3 \mathrm{~m}$ high), bordered by aspen woodland (28 and 30 individuals in 1979 and 1980, respectively), than another study plot composed primarily of aspen woodland, with lesser amounts of habitat in grass and shrubs (16 individuals in both 1979 and 1980). It is worth noting that the aspen woodland was dense enough to provide little understory, due to a large amount of leaf litter and little light penetration (Burachynsky and Galloway 1985). Reichardt and Galloway (1994) captured S. franklinii in habitat they characterized as aspen-oak parkland, which included trembling aspen $(P$. tremuloides), bur oak (Quercus macrocarpa), and various shrub species. In 1982 these researchers captured 36 individual squirrels (95 total squirrel captures in 552 trap days), and in 1983 they captured 40 individual squirrels (161 captures in 504 trap days).

Sargeant et al. (1993) recorded S. franklinii from study sites located in proximity to Moore Park and Cartwright in southwest Manitoba (Table 3). In their study, the highest observation rate of S. franklinii, out of all 33 study sites, occurred at Moore Park (Sargeant et al. 1993). Sargeant et al. (1993) ranked $S$. franklinii as "common" at Moore Park, which was in the aspen parkland zone, and "uncommon" at Cartwright, which was in the prairie zone (Table 3 ).

Hare (2004) studied kin discrimination in $S$. franklinii near Delta Marsh, where the species continues to persist and be utilized as a study organism.

Of note, one early reference about $S$. franklinii in the Aweme area asserted that, "[It] does more harm during the period of its activity than any other member of the genus" (Criddle 1929, p. 157). This statement presumably refers to the propensity of $S$. franklinii to consume agricultural products. Both Sowls (1948) and Lynch (1972) documented $S$. franklinii as a predator of duck nests.

Ontario. The distribution of $S$. franklinii in Ontario is limited to the extreme western edge of the province (Fig. 2), in proximity to both the Manitoba and Minnesota borders. The range of $S$. franklinii appears to have expanded eastward into Ontario within the last century, presumably because of human modifications of habitat, specifically the clearing of land for agriculture (Peterson 1966). Snyder (1938) recorded the first specimens of $S$. franklinii collected from the province. He stated, "Apparently this animal is a fairly recent arrival in the district-certainly it was not present when the area was opened up for agriculture" (p. 169). He reported that the first visual observation of $S$. franklinii in Ontario came from the Rainy River area in June 1925. Snyder (1938) implicated modification of the land in the spread of $S$. franklinii in Ontario when he stated, "As further evidence of its recent arrival it can be said that it is rapidly spreading eastward over cultivated sections. It now [1936] occurs at Emo, which indicates an advance of some twenty-five or thirty miles in seven years" (p. 169). He included $S$. franklinii in a suite of mammals characteristic 
of western prairie regions. No specific mention of the habitat surrounding his trapping locations for $S$. franklinii were given, but the area as a whole was a mixture of small agricultural lands set in and among areas characterized by stands of aspen and spruce (Snyder 1938). Peterson (1966) recorded S. franklinii from the Kenora, Rainy River, and Fort Francis areas of Ontario, a distribution reiterated by Dobbyn (1994).

Saskatchewan. Franklin's ground squirrel occurs in the southern third of Saskatchewan, excepting the southwest corner of the province (Fig. 2). The original species description of $S$. franklinii was based on specimens collected by Sir John Richardson in Saskatchewan (Sabine 1822). Richardson (1829) described the location where these first specimens were collected by stating, "This animal was seen in the neighborhood of Carlton-house, where it lives in burrows dug in the sandy soil, amongst the little thickets of brushwood that skirt the plain" (p. 168). In 1895, J. A. Loring (in lit., NMNH archives, Box 122, Folder 21) reported S. franklinii to be common at Wingard, which-according to his notes - was located approximately six miles $(9.7 \mathrm{~km})$ northeast of Carlton-house. He stated, "They were found to be quite thick in the cooleys that run into the river" (in lit., NMNH archives, Box 122, Folder 21). Loring recorded the following information regarding the vegetation of the area: "The country is rolling and covered with patches of thick poplar and quaking asp[en]. Many cooleys run into the river [and] in these may be found two species of poplars[,] Populus angustifolia and Populus tremuloides besides numerous scrub bushes in which willows predominate. A straggling spruce is found here and there as are also birch trees but they are both rare" (in lit., NMNH archives, Box 122, Folder 22). In the same year, Loring recorded the occurrence of $S$. franklinii at Indian Head in Assiniboia (now southern Saskatchewan). He stated, "Three were taken in Red Fox cooley and several others [were] heard and seen. They seemed to prefer the scrub on the banks of the stream" (in lit., NMNH archives, Box 122, Folder 21) In his vegetation notes of the area he recorded the following, "Indian Head...is situated on a beautiful rolling prairie and is a fine farming district. With the exception of a few bunches of willow here and there, no timber is found outside of Red Fox cooley where
Populus tremuloides and Populus angustifolia are abundant being found in small groves" (in lit., NMNH archives, Box 122, Folder 22).

From the earliest accounts of $S$. franklinii in Saskatchewan, this species was associated most commonly with habitat that contained some measure of a woody component either in the form of trees or shrubs. Specimens collected by F. Banfield near Emma Lake (Table 5) in 1939 further illustrate this association.

Soper (1951) reported some of the northernmost records of $S$. franklinii in Saskatchewan, at Prince Albert National Park, and detailed the association of the species with deciduous and coniferous woodlands. He observed two individuals in a small area of black spruce muskeg, others in a poplar woods near open grassland, and found scattered individuals in the "forestprairie" country in the southern end of the park (Soper 1951, p. 29). Beck (1958) stated that the species was widespread in Saskatchewan, but most abundant in the "bushy regions" (p. 28). In regards to prevalence, Soper (1951), again reporting from Prince Albert National Park, found its distribution "notably inconsistent...in many favourable localities it appeared to be absent" (p. 29). Soper (1961b) reiterated this point a decade later for the region of southern Saskatchewan when he said, "Local dispersal and numbers are noticeably irregular-sometimes common, scarce or apparently wanting" (p. 31).

I gleaned additional information concerning $S$. franklinii in Saskatchewan from the parasitology literature. From May to August in 1976 and 1977, 44 S. franklinii were collected near Saskatoon and examined for parasites (Leighton and Wobeser 1978). McGee (1980) examined $46 \mathrm{~S}$. franklinii for parasites from Saskatchewan but did not provide additional details on collecting localities. Some of the specimens he examined may have included those collected by Leighton and Wobeser (1978) because the time frame is similar. In 1986 and 1987, Durham et al. (1988) examined a total of 13 S. franklinii: 11 from the vicinity of St. Denis (40 km east of Saskatoon) and 2 from near the South Saskatchewan River on the outskirts of Saskatoon. None of these parasitological studies provide specific information on the habitat from which the squirrels were collected.

The highest populations of $S$. franklinii found by Sargeant et al. (1993) in their study 
Table 4. Notes on Franklin's ground squirrel, Spermophilus franklinii, in Manitoba.

\begin{tabular}{|c|c|c|c|}
\hline Locality & Habitat & Abundance & Citation \\
\hline Manitoba & $\begin{array}{l}\text { "Its chief region ...is the poplar } \\
\text { country from Pembina to Pelly" (p. 373). } \\
\text { "[found] frequenting the edges of thick } \\
\text { dry undergrowth near woodlands or } \\
\text { along hedges" (p. 373). }\end{array}$ & $\begin{array}{l}\text { "In } 1882, \text { we, in Manitoba, reckoned } \\
\text { this the rarest of the Ground-squirrels; } \\
\text { since then it has increased... while the } \\
\text { Striped Ground-squirrel has decreased, } \\
\text { so that now this is much the more } \\
\text { numerous of the two" (p. } 375 \text { ). }\end{array}$ & Seton 1910 \\
\hline $\begin{array}{l}\text { Spruce Woods } \\
\text { Forest \& } \\
\text { Game } \\
\text { Preserve }\end{array}$ & $\begin{array}{l}\text { Found in the deciduous forest community } \\
\text { composed almost entirely of aspen } \\
\text { (Populus tremuloides). }\end{array}$ & $\begin{array}{l}\text { Listed as plentiful, along with other } \\
\text { mammals in a long list. }\end{array}$ & Bird 1927 \\
\hline $\begin{array}{l}\text { Manitoba } \\
\text { general }\end{array}$ & $\begin{array}{l}\text { "[They] range primarily in the Transition } \\
\text { Zone, but overlap into 'pure' Canadian } \\
\text { types along the northern fringe of their } \\
\text { range in Canada. They are animals of } \\
\text { the 'edge.' Their favorite habitat is the } \\
\text { area where woods and open country meet" } \\
\text { (p. 134). }\end{array}$ & $\begin{array}{l}\text { "population densities are extremely } \\
\text { variable over a period of years and } \\
\text { cyclic declines and rises are in evidence" } \\
\text { (p. 135). }\end{array}$ & Sowls 1948 \\
\hline $\begin{array}{l}\text { Riding } \\
\text { Mountain } \\
\text { National Park. }\end{array}$ & $\begin{array}{l}\text { "it resorts to habitats in both Transition } \\
\text { and Canadian Life zones" (p. 22) }\end{array}$ & $\begin{array}{l}\text { "This species of ground squirrel does } \\
\text { not appear to be as commonly dispersed } \\
\text { as the two referred to above }[\text { S. tri- } \\
\text { decemlineatus and S. richardsonii]" } \\
\text { (p. 22). }\end{array}$ & Soper 1953 \\
\hline Delta Marsh & $\begin{array}{l}\text { "This species was the only squirrel } \\
\text { inhabiting the wooded lake ridges and } \\
\text { stream and marshland borders south of } \\
\text { Lake Manitoba" (p. 74). }\end{array}$ & $\begin{array}{l}\text { "When trapping started in early June } \\
\text { only a few adult animals were present. } \\
\text { However, by late July juvenile and young } \\
\text { adult animals were seen in large numbers" } \\
\text { (p. } 74 \text { ). }\end{array}$ & Tamsitt 1962 \\
\hline
\end{tabular}

Table 5. Museum specimens of Franklin's ground squirrels, Spermophilus franklinii, collected by F. Banfield from Saskatchewan.

\begin{tabular}{|c|c|c|c|c|c|}
\hline Date & Museum & $\begin{array}{l}\text { Museum } \\
\text { Number }\end{array}$ & Locality & Collector & Notes from museum tag \\
\hline 1 July 1939 & $\mathrm{CM}$ & 18202 & Emma Lake & F. Banfield (\#250) & "dry, mixed woods" \\
\hline 5 July 1939 & $\mathrm{CM}$ & 18204 & Emma Lake & F. Banfield (\#267) & $\begin{array}{l}\text { "bushes on edge of grassy } \\
\text { flats" }\end{array}$ \\
\hline 29 June 1939 & UMMZ & 83626 & $\begin{array}{l}\text { Prince Edward } \\
\text { Dist., Emma Lake }\end{array}$ & F. Banfield (\#242) & $\begin{array}{l}\text { "grassy flats on edge of } \\
\text { spruce woods" }\end{array}$ \\
\hline 1 July 1939 & UMMZ & 83627 & $\begin{array}{l}\text { Prince Edward } \\
\text { Dist., Emma Lake }\end{array}$ & F. Banfield (\#253) & "forest edge on grassy flats" \\
\hline 6 July 1939 & UMMZ & 83628 & $\begin{array}{l}\text { Prince Edward } \\
\text { Dist., Emma Lake }\end{array}$ & F. Banfield (\#272) & $\begin{array}{l}\text { "bushes on edge of grassy } \\
\text { flats" }\end{array}$ \\
\hline
\end{tabular}


on predators that affect duck production were in Saskatchewan. Specifically, they found $S$. franklinii at 9 of 10 sites in Saskatchewan from 1983-1985 at localities near Ceylon, Craik, Earl Grey, Goodwater, Hanley, Inchkeith, Leask, Shamrock, and Yorkton (Sargeant et al. 1993 and Table 3). The two sites in Saskatchewan where $S$. franklinii was most prevalent included Earl Grey and Hanley; the Earl Grey study site was the only locality in the entire study where $S$. franklinii was ranked as "numerous" (Sargeant et al. 1993 and Table 3).

\section{United States}

Bailey (1893) provided one of the earliest accounts of $S$. franklinii specific to the U.S. He declared, "Franklin's Spermophile is characteristic of prairies and open country, is never found in heavy timber, and does not climb trees. The places usually selected for their holes are among tall grass, weeds, and scattered brush. Often they are found living along the edge of timber that adjoins the prairie or in small groves" (p. 51). Notes on the local abundance of $S$. franklinii, provided by Bailey (1893), are included in the accounts that follow.

Illinois. The earliest account of S. franklinii from Illinois (Fig. 2) that I found was R. Kennicott's catalog of the animals of Cook County (Kennicott 1855). In that brief publication Kennicott said the following about $S$. franklinii: "Common. Gregarious, migratory. Found on the prairies throughout the state" (p. 579). Two years later, Kennicott published a more complete account of the mammals of Illinois in what has become a well-known work, "The Quadrupeds of Illinois, Injurious and Beneficial to the Farmer" (Kennicott 1857). In that publication, Kennicott said of S. franklinii, "It is far less numerous here than the striped spermophile, and appears to be a less abundant species wherever the two exist. It is observed to inhabit the thickets of low bushes, and the edges of the timber, more than the other, but does not occur in the woods" (p. 648). He provided one of the earliest accounts of variation in local abundance of $S$. franklinii when he stated, "In several instances, a company of a dozen or more have been observed to appear in a locality where none were seen the previous summer, and then to disappear after remaining there a year, or only a few weeks" (p. 648).
The relationship between $S$. franklinii and the human inhabitants of Illinois as illustrated by Kennicott (1857) may hint at one factor responsible for the unpredictable nature of the species' local abundance. Apparently, S. franklinii often was considered an agricultural pest because it consumed newly planted corn and occasionally fed on poultry, either as eggs or chicks (Kennicott 1857). On one farm where $S$. franklinii was considered the guilty party, "a war of extermination was commenced. Several were shot, while others were killed with clubs, whereupon the survivors left, in a body, as suddenly as they had come, and were never seen again, nor could they be found upon any part of the farm" (p. 649). At least in parts of Illinois, the "wars of extermination" were successful. In 1892, G. Coleman (in lit, NMNH, Box 55, Folder 1) recounted, "An old farmer told me that fourteen years ago the gray and striped gophers were very numerous...but that they were now nearly all gone. He had not seen one this year."

By 1910 , accounts of $S$. franklinii in Illinois mentioned their close association with agricultural land. Wood (1910) relayed, "At present a necessary condition for their habitation seems to be the presence of some shelter, such as may be furnished by tall grass, or a field of clover, alfalfa, or grain" (p. 529). This statement reflects on the adaptability of $S$. franklinii as well as the changing landscape of Illinois. Wood (1910) ranked the habitats where S. franklinii occurred in Champaign County from greatest to least abundance as follows: moraine bluff, till plain, and cleared pasture. Interestingly, he did not list S. franklinii from his "wooded bluffs" or "groves" categories although he stated, “...I presume that they may be found in the borders of woodlands" (p. 530).

Cory (1912) added little new information about $S$. franklinii in Illinois inasmuch as his account of the species was extracted primarily from Kennicott (1857). He provided the following summary of $S$. franklinii's distribution: "In Illinois it is found in scattered communities throughout the greater portion of the central and northern portion of the state" (Cory 1912, p. 145, 147). Mohr (1943) mapped the distribution of every ground squirrel he observed between 1931 and 1942 for the Illinois Natural History Survey and found S. franklinii limited to the northern two-thirds of the state. In this area Mohr stated, “...I have observed Franklin's ground squirrels at almost as many 
localities as woodchucks and have seen striped ground squirrels [S. tridecemlineatus] at two or three times as many localities" (p. 177). Anderson (1951) detailed S. franklinii's presence in Fulton County in west-central Illinois as follows: "...[it] probably occurred throughout the county in prairie areas along railroads, highways, and in overgrown pastures" (p. 175). Anderson (1951) caught both S. franklinii and $S$. tridecemlineatus at her three trapping localities. Hoffmeister and Mohr (1957, p.139) called S. franklinii "common" in the northern two-thirds of Illinois in what was originally the prairie region. Their brief account stated that $S$. franklinii was found in areas of tall, thick grass with more brush than those areas frequented by S. tridecemlineatus (Hoffmeister and Mohr 1957).

In the spring of 1954, many species of wildlife were affected deleteriously when dieldrin, a highly toxic chlorinated hydrocarbon insecticide, was employed against a local infestation of Japanese beetles, Popillia japonica, in the area of Sheldon, Illinois, along the Indiana border (Scott et al. 1959). According to Scott et al. (1959, p.417), both $S$. tridecemlineatus and $S$. franklinii, which had been common in the area, suffered "virtually annihilative losses" in the wake of the insecticide application. Scott et al. (1959) reported that "some farmers expressed satisfaction that the dieldrin had freed their lands of ground squirrels" (p. 417). This account clearly indicated the potential negative effects that pesticide applications may have had on $S$. franklinii populations throughout much of their geographic range - where agricultural lands dominate-before the advent of stricter regulations concerning the use of these toxic chemicals.

Gray (1972) studied S. franklinii at the Illinois State University farm located near Normal, Illinois, in 1971 and 1972. He indicated that, in McLean County, S. franklinii was found mostly in hay fields and on embankments along railroad rights-of-way. In the early 1970s, McLean County was intensively farmed; idle land was limited to streambanks, roadsides, railroads, and small woodlands along streams (Gray 1972).

Van Petten and Schramm (1972) were the first researchers to strongly tie $S$. franklinii to tallgrass prairie habitat in Illinois. In their paper's introduction, they mentioned that $S$. franklinii inhabited tall grassy areas and im- mediately followed that comment with, "This tall grass habitat preference suggests that it [S. franklinii] is a climax species of the tall grass prairie" (Van Petten and Schramm 1972, p. 166). They linked perceived declines of $S$. franklinii to prairie habitats when they stated "over much of the Midwest it is absent because of destruction of suitable habitat by mowing, grazing, and cultivation" (Van Petten and Schramm 1972, p. 166). Their study detailed the introduction of a transplanted population of $S$. franklinii at the Knox College Biological Field Station. Further studies on this introduced population resulted in publications that reiterated that $S$. franklinii preferred tallgrass prairie habitat (Krohne et al. 1973, Krohne and Schramm 1992).

Like the efforts by those at the Knox College Biological Field Station to establish a population of S. franklinii on the station's restored prairie, others introduced S. franklinii to Gensburg Markham Prairie located near a south-Chicago suburb (Panzer and Schipp 1986). This introduction was in response to concerns that the species was disappearing from the surrounding environments. Clearly, conservation concern existed for populations of $S$. franklinii in Illinois as early as the 1970s and 1980s. Because $S$. franklinii became strongly linked to tallgrass prairie habitat at this time, the disappearance of the prairie and the squirrel became linked.

Spurred on by reported population declines in S. franklinii, Lewis and Rongstad (1992) examined changes in the distribution of the species in Illinois and Wisconsin. They gathered reports of $S$. franklinii from 22 locations in 16 counties in Illinois in 1985 and 1986 and concluded that it had a "relatively stable range in Wisconsin and Illinois" (p. 60). Although they did not document a decline, and in fact stated that precise data to do so were lacking, they reported that many of their sources (from mail surveys) perceived a decline. Lewis and Rongstad (1992) speculated on possible reasons for the purported decline which included: 1) $S$. franklinii may never have been common in certain regions of Wisconsin and Illinois, 2) negative effects of changes in land-use, and 3) deleterious effects associated with isolation of fragmented populations.

Hoffmeister (1989) summarized the biology of $S$. franklinii in Illinois but provided little new information. He made no mention of the species abundance or rarity within the state but said 
it preferred grasses of intermediate height.

In 1998 Joyce Hoffmann, a mammalogist for the Illinois Natural History Survey, searched for S. franklinii at 12 sites in east-central Illinois (9 sites in Champaign County and 3 sites in adjacent Vermilion and Piatt counties) to establish the current status of the species in the state (Hoffmann 1999). She trapped known localities of historic occurrence of the species. In 1,032 trap-days she captured only one adult male $S$. franklinii along an abandoned railroad right-of-way (Hoffmann 1999).

In a related endeavor, Martin et al. (2003) conducted a mail survey of 166 wildlife professionals in Illinois with the objective of assessing the status of $S$. franklinii throughout its historic range. Nine extant populations were reported in the mail survey, in addition to 44 possible populations (based on unconfirmed sightings). Mail survey results, coupled with historic records and current habitat, were used to select 26 sites for live-trapping surveys of $S$. franklinii. Martin et al. (2003) confirmed the presence of $S$. franklinii at only three trapping sites. One population occurred in Champaign County at a restored prairie and two populations, separated by only $3 \mathrm{~km}$, occurred on the same railroad right-of-way in Vermilion County, on the Indiana border (Martin et al. 2003). Based on these results, Martin et al. (2003) concluded that $S$. franklinii has declined in Illinois, but they refrained speculation on the magnitude of the decline because of the inherent difficulties in surveying for this animal.

Pergams and Nyberg (2001) concluded $S$. franklinii had declined in the Chicago region based on the rate of museum specimen deposits, and linked the decline to loss of prairie habitat in the area. Based on their data and other recent data presented here, Pergams and Nyberg (2001) suggested that S. franklinii be placed on the Illinois list of Threatened and Endangered Species and, in February 2004, S. franklinii was listed as Threatened in Illinois (in writ., Illinois Endangered Species Protection Board 2004).

Recent publications by Martin and Heske (2004, 2005), both based on the S. franklinii population found by Martin in Champaign County, contribute further to understanding $S$. franklinii in Illinois. In one study focused on $S$. franklinii burrow placement, the authors found that more than one-third of burrow systems were "within $5 \mathrm{~m}$ of trees, trash heaps and buildings, whereas this habitat comprised only $9.5 \%$ of the study area" (Martin and Heske 2004, p. 229). Burrow systems also occurred disproportionately in drained soils covered by cool season grasses (Martin and Heske 2004). The authors noted that cool season grasses afford cover, forage, and nesting material at the time when the squirrels are emerging from hibernation.

In Martin and Heske (2005) a valuable glimpse into juvenile dispersal behavior in $S$. franklinii is provided. The authors reported the following: males dispersed further than females, both sexes may disperse over $1 \mathrm{~km}$, agricultural fields with cover in the form of row crops may not be a hindrance to dispersal, but there is indication that for some individual $S$. franklinii roadways may serve as barriers. The authors suggest that further research on dispersal in S. franklinii is needed to inform management decisions concerning the species.

Indiana. The distribution of S. franklinii reaches its eastern limit in the northwestern corner of Indiana (Fig. 2). The earliest definitive record of $S$. franklinii in the state was in 1884 , but the earliest reference may have been in 1819, as reported by Mumford and Whitaker (1982), who provided a detailed chronology of S. franklinii in Indiana. Bailey (1893) reported this squirrel from only two localities, both at the western edge of the state-Kentland and Earl Park. Hahn (1909) speculated that $S$. franklinii probably did not occur in more than five or six counties in Indiana. At Mount Ayr, Hahn (1909) found them "living about a stone pile in a field of oats" (p. 478). It was the only colony in the area. He commented further, "The animals were not afraid of traps and three were caught in a single trap, without bait, in two days" (Hahn 1909, p. 479).

M.W. Lyon, Jr. (1932) detailed the status of $S$. franklinii in Indiana in one of the earliest articles devoted solely to the species from any locality. Lyon (1932) believed that S. franklinii originally was limited to the prairie portion of Indiana because of its terrestrial nature but "with the clearing off of the timber and rendering much of the state an artificial prairie it...spread a few miles to the eastward" (p. 16). Lyon (1932) claimed that S. franklinii was "comparatively rare in Indiana" (p. 17). Probably for that reason he detailed all the animals he observed or that were reported to him within the state from 1930 to 1932 . On 25 August 
1930 he encountered a badly smashed and decomposing $S$. franklinii on a road in Pulaski County (Lyon 1932). That record may be the first account of a road-killed S. franklinii.

In his Mammals of Indiana, Lyon (1936) added little new information to his preceding account of $S$. franklinii. He reiterated their rarity in the state emphasized by his comments that "in counties where they are known to occur, it is often difficult to find persons who are familiar with them" (p. 186) and "on about three occasions have I seen it running across a road... while the Thirteen-Striped GroundSquirrel is seen running across roads everywhere" (p. 187). He found the squirrels only in open fields and meadows.

Kirkpatrick and Conaway (1948) reported $S$. franklinii from new localities in Indiana, including a reputed colony along a railroad embankment located between Battle Ground and Ash Grove in Tippecanoe County. They speculated that $S$. franklinii seemed to have a preference for habitat provided by railroad fills (Kirkpatrick and Conaway 1948). Mumford (1969) summarized current records of $S$. franklinii in Indiana and restated the species' preference for habitat along railways. Whether that statement was based on personal observation or the previous account of Kirkpatrick and Conway (1948) is not certain. He reported the status of the species as uncommon to rare (Mumford 1969).

Mumford and Whitaker (1982) thoroughly reviewed the status of $S$. franklinii in Indiana. They reported $S$. franklinii from 16 contiguous counties in the northwest corner of the state, having observed the squirrel from 13 of those counties themselves (Mumford and Whitaker 1982). Like Lyon $(1932,1936)$, they found it difficult to find persons who had seen the squirrel or were at all familiar with it (Mumford and Whitaker 1982). Most observations of $S$. franklinii in Indiana occurred along roadsides or railroad embankments where the habitat was characterized by tall grass, weeds, and occasionally the presence of shrubs and small trees (Mumford and Whitaker 1982). They noted that, despite the presence of favorable habitat, $S$. franklinii had not expanded its range in Indiana to the degree that $S$. tridecemlineatus had.

In 1984, the Indiana Department of Natural Resources (DNR) listed S. franklinii as a species of "special concern" because of its limited distribution in the state (in Johnson and
Choromanski-Norris 1992). That same year, the Indiana DNR began to assess the current distribution of $S$. franklinii in Indiana relative to its historic range in the state (Johnson and Choromanski-Norris 1992). The study, which occurred from 1984-1990, reported 120 individual S. franklinii captured from 370 surveyed sites, 139 total $S$. franklinii captures (including recaptures) in 5,161 trap days, and $S$. franklinii found at only $9.7 \%$ of sites surveyed in 9 of 16 historically occupied counties (Johnson and Choromanski-Norris 1992). Most captured squirrels (96/120) were found at railroad right-of-ways that comprised $80 \%$ of all survey sites (Johnson and Choromanski-Norris 1992). Johnson and Choromanski-Norris (1992) suggested that cooperative efforts between state agencies to manage right-of-ways for grassland habitat, and potential reintroductions of squirrels on state managed lands, might help the recovery of $S$. franklinii populations in Indiana.

Benjamin (1991) initiated a study of $S$. franklinii focused primarily on its habitat use in Indiana. He offered the following conclusions: "This study...showed that this species is not dependent on native prairie" (p. 48), and "This and previous studies suggest that vegetation characteristics alone do not determine habitat selection by S. franklinii" (p. 47). As a result of the preceding studies, S. franklinii was listed as "state endangered" in Indiana in 1990 (S. Johnson, Indiana DNR, pers. comm.).

In the summer of 1994, Lotter (1994) resurveyed 36 sites where S. franklinii had occurred according to Johnson and Choromanski-Norris (1992). She captured 29 S. franklinii in 1,635 trap days at 8 of 36 sites in 3 of 9 counties surveyed (Lotter 1994). She concluded that the geographic range of $S$. franklinii in Indiana had been "substantially" reduced due in part to dramatic habitat alteration of some sites (Lotter 1994, p. 7). One site was occupied by a new subdivision and another, at a railroad rightof-way, was severely disturbed when tracks were removed (Lotter 1994). In her words, the "reduction in range is most likely due to the loss of suitable habitat, due to changing farming practices and development of the northwest corner of the state" (Lotter 1994, p. 7).

Iowa. The earliest account of $S$. franklinii in Iowa that I found came from J.A. Allen (1871), who worked in the state in 1867. At that time he found the species "abundant" and noted that 
"when very numerous they sometimes destroy acres of newly planted corn by eating the seed" (Allen 1871, p. 189-90). He continued, "During the spring months it is generally numerous, but after about the first of June is rarely observed, and all my efforts to obtain specimens, both in this state and in Illinois, where it is equally common, were ineffectual" (Allen 1871, p. 190).

In Council Bluffs in 1892, George Coleman (in lit. NMNH, Box 55, Folder 37) reported, "Both the striped and gray [Spermophilus] were here a few years ago but the boys have caught them all. At least none have been seen lately." In contrast, Van Hyning and Pellet (1910) said they were common throughout the state. In a similar vain Ruthven and Wood (1912, p. 204) stated, "The species is less common than $C$. tridecemlineatus but is far from rare." Spurrell (1917, p. 283) observed: "It is now common in clover and timothy fields; and when the hay is cut it removes to the grain fields and digs new burrows. It is very rarely found in pastures... this species was not as common in early days as it is now."

In The Rodents of Iowa Stoner (1918) provided the most detailed, historic account of $S$. franklinii in Iowa.

"Franklin's spermophile is an inhabitant of open prairies and is not found in timbered regions, although it often lives along the edges of timber and small groves.

At Lake Okoboji it is quite common near the sparse woods and groves bordering the water, and has even taken up its abode near the buildings of the Lakeside Laboratory. In most places it is not as common as the striped spermophile although in a few localities it is reported as more common than that species (p. 36-37)...This species is more migratory in its habits than the striped spermophile; the males live a wandering life during the summer, and indeed pairs or even small companies of individuals frequently migrate from one locality to another; sometimes a pair will migrate from the wintering burrow to a breeding burrow and perhaps winter in still another. This migratory habit may account for the reports received from various places to the effect that 'this species was common here last summer, but I have seen only a very few this year (p. 37).'...Although this form is quite generally distributed throughout the state, in the driftless region of northeastern Iowa it is not commonly met with. It seems, however, to be working its way into this region from the north and west, and a few miles west of the hilly section it is fairly common. At Corning it is reported that this species did not appear until 1909; now it is abundant in that locality. In almost every locality visited Franklin's spermophile is found; but its numbers are, in general, less than those of the striped spermophile ( $\mathrm{p}$. 37-38)...Franklin's spermophiles have long been recognized as enemies of agricultural interests and the expedient of offering bounty has been resorted to in various counties in the hope of either exterminating them or materially reducing their numbers. These sporadic attempts have not met with any degree of success. Although it is apparent that this species is recognized as more destructive in its habits than the striped spermophile, the added incentive to its capture in the way of a larger bounty offered has proved of no avail” (p. 39).

Information about $S$. franklinii in Iowa during the middle part of the $20^{\text {th }}$ century is rare. Gabrielson (1921) stated the species was common in Marshall County, and Scott (1937) indicated it was found statewide after having spread into areas opened by agriculture. Both Errington (1937) and Snead and Hendrickson (1942) found S. franklinii remains in badger scats from Iowa. Polder (1965) thought $S$. franklinii probably was present in every county in Iowa in "favored habitats such as 
hay fields, oats fields, weedy fence rows and native prairie" (p. 202). He speculated further that the "...border zone between low wet soils formed under Spartina and soils formed under Andropogon appears to be the optimum habitat both on native prairie and on cultivated lands" (Polder 1965, p. 202), but provided no support for this statement.

Bowles (1975) reported that S. franklinii was found locally throughout the state. Accordingly, he stated: "Prior to the settlement of Iowa, the Franklin's ground squirrel was common only in the tall-grass prairie of the central and western parts of the state. Clearing of forested areas in southern Iowa and the planting of hay crops undoubtedly increased available habitat" (Bowles 1975, p. 65). More recently Bowles (1981) listed S. franklinii as a mammal species declining in Iowa and attributed the decline to loss of significant areas of tallgrass prairie habitat.

Kansas. The southwestern limit of $S$. franklinii's distribution is reached in Kansas (Fig. 2) where the squirrel is uncommon and, when present, most often is associated with brushy, grassland areas (Table 6). In the earliest reports of $S$. franklinii in Kansas, the squirrel's impacts on agriculture were the focus. A portion of a letter by L. L. Dyche, biology professor at the University of Kansas, sent to Vernon Bailey in 1888 stated: "Not much damage is done by this species...except in certain localities...The squirrels dig up the corn (and sometimes other seeds) soon after it is planted in the spring and in the fall do some damage by burrowing under corn shocks...We killed many of them with guns and tried to poison them, with apparently very little success" (Bailey 1893, p. 52-3).

Remington Kellogg (1915) prepared his Master's thesis on the mammals of Kansas and provided a detailed account of $S$. franklinii. Unfortunately it is not clear how much of that account was based on observations from Kansas. Whereas Kellogg (1915) examined only four $S$. franklinii specimens from Kansas, he frequently observed the species in North Dakota in the summer that preceded the writing of his thesis (see Table 8). Nevertheless, his comments provide an historic insight that warrants repeating here. He found that S. franklinii "is not common in the open prairie country as it depends on the cover of brush and timber" (Kellogg 1915, p. 162) and reinforced Dyche's earlier observations with the following comments: "Franklin's spermophile is exceedingly destructive to corn. They dig up the corn after it is planted in the spring and eat out the kernel. This frequently necessitates replanting. In some localities their depredations are so destructive that the farmers sow the fields with poisoned corn before planting" (Kellogg 1915, p. 163).

In contrast to the abbreviated commentary most authors afforded $S$. franklinii in Kansas, Andersen and Fleharty (1967) provided specific details on the habitat associations of a $S$. franklinii population they located in northeastern Jewell County in 1964. The habitat was dominated by smooth brome (Bromus inermis) over two feet in height, but also contained Maxmillian sunflower (Helianthus maximilianii), Indian hemp (Apocynum cannabinum), smartweed (Polygonum spp.), stinging nettle (Urtica dioica), and smooth sumac (Rhus glabra). Along one edge of the area were several wild plum (Prunus sp.) thickets (Andersen and Fleharty 1967). They collected two squirrels, and found seeds of smartweed, wild plum, and beetle remains in their stomach contents. An opened cache of wild plums was located near one of the burrows (Andersen and Fleharty 1967).

By 1973, Platt et al. (1973) listed S. franklinii as rare in Kansas and indicated that isolated populations occurred in relict areas of tallgrass prairie. In an effort to supplement the squirrel's habitat needs, the authors tried to encourage landowners to leave a swath of native grass around plowed fields. They also encouraged the highway department to permit native prairie cover to develop along roadsides and to minimize mowing (Platt et al. 1973).

Minnesota. Vernon Bailey, active in the formative years of the U.S. Biological Survey, provided many of the earliest accounts of $S$. franklinii. He first observed the species at Elk River, Minnesota, in 1872 (Bailey 1893). They 
were scarce at that location, and he saw only 6 to 8 individuals a year for the 14 summers he lived there (Bailey 1893). Notes on $S$. franklinii from Bailey and others employed by the U.S. Biological Survey are in Table 7. At other localities in Minnesota, S. franklinii was more common. At Ortonville in Big Stone County in 1887, they were abundant and Bailey (1888, p. 438) wrote, "A few are scattered over the prairie, but in the timber near the lake, and in the ravines, there are a great many... On the prairies they are mostly found near grain-fields or in marshy places." In the same year at Brown's Valley in Traverse County, he wrote, "Occasionally found on the prairie, and very numerous all over the valley, even in town" (Bailey 1888, p. 439).

As early as 1892, Herrick (1892) recognized declining populations of $S$. franklinii in southern Minnesota. He stated, "This graceful animal was at one time fairly abundant throughout the southern part of Minnesota, but is being rapidly exterminated by civilization" (p. 167). He added, "It is still abundant about Big Stone Lake [on the western border of Minnesota near the North Dakota / South Dakota border], where it will approach the traveler's tent fearlessly and may be taken by the hand if desired" (Herrick 1892, p. 167). Herrick (1892) said that $S$. franklinii is found "about the edges of copses and it is not unusual for the animal to take refuge in a low tree or close thicket rather than its burrow" (p. 167).

The carnivorous tendencies of $S$. franklinii were first noted by A.M. Johnson (1922), who relayed his account of an attack on a rabbit in a "vacant yard in the forest of western Aitkin County" (p. 187) in Minnesota. C.E. Johnson (1930), writing of his experiences in northwestern Minnesota during the years 1889-1902, recalled of S. franklinii, "On our homestead it was of rather common occurrence along the banks of the coulee and along the margins of the fields, where tall weeds, grass or scattered shrubbery formed suitable habitats" (p. 445).

Fifty years after Herrick (1892) noted declining populations of $S$. franklinii in southern Minnesota, Swanson et al. (1945) declared the following: "The Franklin ground squirrel is no longer a common species in the southern part of the state, but in the northwestern counties it is quite abundant. In 1932 I found it as common as the striped species in Lake of the Woods and Roseau counties" (p. 77-8). Swanson et al. (1945) considered Lake of the Woods and Roseau counties, both found along the Canadian border, to be boreal habitat.

Gunderson and Beer (1953) summarized accounts of $S$. franklinii in Minnesota and mapped sites of its verified occurrence in the state. Of its habitat associations, they stated "It prefers brushy fields, and in Minnesota is often found in rock piles at the edges of woods" (Gunderson and Beer 1953, p. 77).

The long-term presence of $S$. franklinii at the University of Minnesota's Field Station at Itasca State Park in north-central Minnesota, which lies within the coniferous forest zone, has resulted in three publications involving the squirrels. Orr (1958) conducted a short-term behavioral study of S. franklinii at the field station, Haggerty (1968) conducted one of the first ecological studies devoted to S. franklinii, and Erlien and Tester (1984) analyzed population dynamics of all squirrels in the park. The results of Orr (1958) add little to the discussion here, but results from Haggerty (1968) and Erlien and Tester (1984) deserve further mention.

Haggerty (1968) observed S. franklinii in and near picnic areas and campgrounds within Itasca State Park and at the field station's property. Mowed areas with scattered clumps of trees, shrubs, and tall herbaceous vegetation characterized these areas (Haggerty 1968). She indicated that $S$. franklinii utilized mowed areas only when in proximity to brush or areas of tall grass. Based on trapping efforts during 1954-1966 by her and students in a vertebrate ecology class taught at the field station, 193 individual S. franklinii were captured, including 63 adults and 130 juveniles. An additional 66 squirrels were captured from three years of intermittent trapping at picnic grounds within the park (Haggerty 1968). Haggerty (1968) documented population fluctuations in $S$. 
Table 6. Notes on Franklin's ground squirrel, Spermophilus franklinii, in Kansas.

\begin{tabular}{llll}
\hline Locality & Habitat & Abundance & Citation \\
\hline Kansas & "Not common" (p. 22). & Knox 1875 \\
Kansas & "Found in most parts of the state; Lantz 1905 \\
& not common" (p. 173).
\end{tabular}

Geary County, "small pastures and fields on the along the upland back of the bluffs" (p. 143).

Missiouri River

\section{Kansas}

Leavenworth

County, Fort

Leavenworth

Military

Reservation

Kansas

Lyon County

Kansas

Kansas "prefer denser cover than the other Kansas species, and are usually found in bushy or grassy border lands" (p. 176).

Missouri River bank. buckbrush-sumac association.

"They prefer denser cover than the other Kansas ground squirrels, and are usually found in the brushy or grassy fence rows and in pasture lands" (p. 128). "extremely rare along periphery of the range; not common anywhere in Kansas" (p. 176).
Black 1937

Brumwell 1951

Cockrum 1952

"Scarce" (p. 190).

Clarke et al. 1958

"Fisherman and other sportsmen frequently report seeing 'large ground squirrels' in the park [Lyon County State Park]” (p. 190).

"One that my dog caught one Hall 1955

"makes its home where the vegetation is so high that the animal cannot see over it and so dense that the animal cannot see through the vegetation for more than a few feet" (p. 95).

and a half miles south of Le Loup, Franklin County, was the only one seen in the seven years that I lived there" (p. 95).

Uncommon (part of this is due Bee et al. 1981 to its wary nature). and deciduous forest come into contact. It prefers the sheltered cover of dense grasses, weedy fields and wastelands, and shrubby forest edges" (p. 91). 
Table 7. Accounts of Franklin's ground squirrel, Spermophilus franklinii, in Minnesota from notes recorded by U.S. Biological Survey personnel contained in the archives at the NMNH.

\begin{tabular}{|c|c|c|c|}
\hline Locality & Habitat & Abundance & Source \\
\hline $\begin{array}{l}\text { Moorhead, } \\
\text { Clay County }\end{array}$ & & $\begin{array}{l}\text { "This animal is seen here } \\
\text { occasionally, but not in any } \\
\text { great numbers." }\end{array}$ & $\begin{array}{l}\text { O.J. Murie } \\
1919 \\
\text { Box } 62 \\
\text { Folder } 24\end{array}$ \\
\hline Minnesota & "I found it fairly common" & $\begin{array}{l}\text { "in the heavy woods on the } \\
\text { Chippewa, where it seemed } \\
\text { especially fond of Norway } \\
\text { pine areas with an under- } \\
\text { growth of hardwoods." }\end{array}$ & $\begin{array}{l}\text { O.L. Augstin, Jr. } \\
1930 \\
\text { Box } 61 \\
\text { Folder } 21\end{array}$ \\
\hline $\begin{array}{l}\text { Itasca Lake, } \\
\text { Clearwater } \\
\text { County }\end{array}$ & $\begin{array}{l}\text { "They occasionally run across the } \\
\text { road but generally keep under cover } \\
\text { of weeds and brush and close to } \\
\text { through their burrows." }\end{array}$ & $\begin{array}{l}\text { "These big gray ground } \\
\text { squirrels with bushy tails \& } \\
\text { minute ears are found through } \\
\text { this region but are rarely } \\
\text { seen." }\end{array}$ & $\begin{array}{l}\text { V. Bailey } \\
1932 \\
\text { Box } 62 \\
\text { Folder } 6\end{array}$ \\
\hline Red Lake & & $\begin{array}{l}\text { "A Franklin's ground } \\
\text { squirrel was seen crossing } \\
\text { the road near the Ranger } \\
\text { Station at Washkish." }\end{array}$ & $\begin{array}{l}\text { V. Bailey } \\
1932 \\
\text { Box } 62 \\
\text { Folder } 6\end{array}$ \\
\hline
\end{tabular}

Table 8. Accounts of Franklin's ground squirrel, Spermophilus franklinii, in Nebraska from notes recorded by U.S. Biological Survey personnel contained in the archives at the NMNH.

\begin{tabular}{ll}
\hline Locality & Habitat \\
\hline $\begin{array}{l}\text { Ames, Dodge } \\
\text { County }\end{array}$ & $\begin{array}{l}\text { "This specimen was the only one } \\
\text { I saw in two days over the prairie." }\end{array}$ \\
& \\
Columbus, & $\begin{array}{l}\text { "4 were caught in small steel traps. } \\
\text { Platte County } \\
\text { prairie land. No. 211 at [a] hole in } \\
\text { an] oat field. The other two were } \\
\text { caught in traps set for Geomys. I } \\
\text { saw several more running on prairie } \\
\text { and in stubble fields." }\end{array}$
\end{tabular}

Kearney,

Buffalo County

\section{Knox County}

Cuming and

Holt counties

\section{Knox County "At Verdigris living in holes in the sides of ravines, and at the bases of hills bordering the valley."}

\begin{tabular}{ll} 
Abundance & Source \\
\hline "I shot one gray spermophile & G. Coleman \\
in a stubble field about 3/4 mile & 1892 \\
N.E. of Ames. The owner of & Box 68, \\
the land told me they were quite & Folder 32 \\
plenty [sic] and took up consider- & \\
able young corn in the spring." & \\
& G. Coleman \\
& 1892 \\
& Box 68, \\
& Folder 32
\end{tabular}

" 2 of the gray species were caught - one preserved...Buffalo 1892 Co. gives a premium of 3 cents Box 68 , each for [something?]. The boys Folder 32 keep them pretty well killed off near town.'

\begin{tabular}{|c|c|}
\hline $\begin{array}{l}\text { "common at Niobrara where a } \\
\text { female killed June } 9 \text { contained } 7 \\
\text { small embryos. They were said } \\
\text { to occur at Verdigre, Knox Co." }\end{array}$ & $\begin{array}{l}\text { V. Bailey } \\
1893 \\
\text { Box } 68 \\
\text { Folder } 14\end{array}$ \\
\hline $\begin{array}{l}\text { "one seen from the car window } \\
\text { [train car] between Beemer and } \\
\text { Wisner. At Ewing a boy } \\
\text { described them and said he had } \\
\text { killed 2, but they were very } \\
\text { scarce." }\end{array}$ & $\begin{array}{l}\text { V. Bailey } \\
1894 \\
\text { Box } 68, \\
\text { Folder } 15\end{array}$ \\
\hline $\begin{array}{l}\text { "Appears to be abundant. } \\
\text { Farmers say it is very } \\
\text { destructive to growing corn." }\end{array}$ & $\begin{array}{l}\text { M. Cary } \\
1903 \\
\text { Box } 68, \\
\text { Folder } 23\end{array}$ \\
\hline $\begin{array}{l}\text { Gray ground squirrels are not } \\
\text { ery common. Near Russell one } \\
\text { f the station employees saw one } \\
\text { dly } 10 . "\end{array}$ & $\begin{array}{l}\text { D.E. Lautz } \\
1910 \\
\text { Box } 68, \\
\text { Folder } 37\end{array}$ \\
\hline
\end{tabular}

$$
\text { July 10." }
$$

Halsey, Thomas County 
franklinii, indicated by the following densities: 0.09 S. franklinii/ha in $1954,0.04$ /ha in 1958 , 0.24 /ha in 1960 and 1961, 0.09/ha in 1963, and 0.08/ha in 1964.

Haggerty (1968) noted $S$. franklinii dispersal throughout the active season, but particularly in May and late summer. Those $S$. franklinii with the greatest tendency to travel long distances included juveniles, spring yearlings, and males, in contrast to adults in general and females in particular (Haggerty 1968). Maximum documented movements of presumed dispersers were $0.8-1.6 \mathrm{~km}$. Some adult males moved as much as $152-304 \mathrm{~m}$ in a few hours (Haggerty 1968). Low survivorship in S. franklinii complicated efforts to gather more detailed information on dispersal. Only 11 of 130 juveniles were recaptured as yearlings, indicating a high rate of mortality and/or emigration during the first year of life (Haggerty 1968). Similarly, maximum known ages of adults were 5 and 2 years, for females and males respectively (Haggerty 1968).

Erlien and Tester (1984) analyzed $S$. franklinii capture rates at Itasca State Park for 1954-1975, incorporating data collected by Haggerty (1968), and reported a periodicity of 10-11 years for population peaks. The cyclic pattern of S. franklinii populations was the strongest of the squirrels tested $\left(\mathrm{r}^{2}\right.$ of 0.81 in serial correlation analysis). They speculated that the cyclic patterns of $S$. franklinii might be the result of prey-switching by predators of snowshoe hare (L. americanus) and ruffed grouse (Bonasa umbellus). Population peaks and valleys of $S$. franklinii lagged behind those of both L. americanus and B. umbellus for the same period (Erlien and Tester 1984).

Accounts of S. franklinii in Minnesota from the last quarter of the $20^{\text {th }}$ Century further detail its presence in the primarily wooded portions of the northern part of the state. Robins (19701971, p. 31) found $S$. franklinii "numerous in the mid-1960s in several public campgrounds on the west side of Lake Winnibigoshish and around Cut-Foot Sioux Lake in Itasca County" in north-central Minnesota. He also reported $S$. franklinii from the Duluth area, in northeastern Minnesota, which previously had fallen outside the geographic range of the species (Robins 1970-1971). Robins (1970-1971) found $S$. franklinii in brushy fields or near the edges of woods. Hazard (1982, p. 63) declared that $S$. franklinii "prefers brushy and partly wooded areas, as well as prairie edges, rather than open prairie" and that this habitat preference, plus a tolerance for people, explains its common occurrence in campsites, state parks, and open dumps. Hazard (1982) updated the distribution of S. franklinii in Minnesota and remarked that the species "has moved north and east into the forest biomes as land has been cleared" (p. 63).

Lewis (1988) examined population structure and reproductive characteristics of $S$. franklinii from animals trapped from the Mid-continent Waterfowl Project in Ottertail, Grant, and Douglas counties in west-central Minnesota. Based on trapping success (measured in trapnights per squirrel), S. franklinii populations increased in those areas from 1984-1987 as follows: 53 squirrels trapped in 1984, 60 in 1985, 118 in 1986, and 155 in 1987 (Lewis 1988). The study area was predominately agricultural (corn, oats, and wheat, primarily), with Waterfowl Production Areas in the area consisting principally of prairie and wetland habitat (Lewis 1988).

Sargeant et al. (1993) reported S. franklinii from all three of their study sites within Minnesota (Table 3). Oak trees were common in woodlots at all three sites and at those near Hawley and Hitterdal, they ranged up to $0.65 \mathrm{~km}^{2}$. The authors ranked the presence of S. franklinii at their Minnesota study sites as either "scarce" or "uncommon" (Sargeant et al. 1993 and see Table 3).

Missouri. I located little information on $S$. franklinii specific to Missouri. Coues and Allen (1877) wrote that the geographic range of $S$. franklinii extended from northern Missouri to the Great Slave Lake in the Northwest Territories of Canada. Although the species does not occur as far north as the Great Slave Lake (one of several geographical inaccuracies in Coues and Allen's account), its geographic range in Missouri is limited to the northern part of the state (Fig. 2).

Schwartz and Schwartz (1981) provided an excellent account of the natural history 
of $S$. franklinii, but it is difficult to ascertain how much of their information is specific to Missouri. They reported it limited to the western and northern parts of the state and indicated that while it occupies the Prairie Region of Missouri "it prefers the marginal habitat afforded by fence rows, wooded banks, gullies, and little-grazed sod" (Schwartz and Schwartz 1981, p. 144).

Ellis (1982) studied a population of $S$. franklinii along a railroad right-of-way located $4 \mathrm{~km} \mathrm{~S}$ of Atlanta in Macon County in the north-central part of Missouri. He captured 47 individual S. franklinii on his study site of 2.4 ha (Ellis 1982). Only 4 of 15 adult squirrels were regularly recaptured, and he thought only 18 of 32 juveniles were born on the site (Ellis 1982). New juveniles were captured on the site from August through early October. $\mathrm{He}$ concluded that many $S$. franklinii captured on his site were transitory animals and that young dispersed in fall (Ellis 1982).

Ellis (1982) identified three traits of his site he felt contributed to the large population of squirrels found there: 1) considerable vegetative cover, principally in the form of grasses (primarily Japanese and smooth brome, $B$. japonicus and $B$. inermis), 2) relatively little disturbance - in contrast to areas that are grazed, hayed, or farmed, and 3) topography and substrate suitable for burrow construction. The site also contained a border of trees along a fencerow and the occasional shrub or tree along the right-of-way that Ellis also felt might be important habitat factors. He believed the lack of disturbance at the site contributed to its vegetative characteristics and the squirrel's continued presence. Unfortunately, he noted that the three habitat traits he identified rarely occurred in areas other than railroad right-ofways in northeast Missouri (Ellis 1982). That statement may hold true for much of the lower Midwest. Nevertheless, Ellis concluded that $S$. franklinii was relatively common in northern Missouri and that the species should not be considered rare, threatened, or endangered in the state. However, he did recommend that, because of the squirrel's preference for tallgrass habitat, prairie should be conserved and restored in Missouri (Ellis 1982).
DeSanty-Combes (2001), biologist for the Missouri Department of Conservation, recently summarized 60 years (1941-2001) of distributional data for $S$. franklinii in Missouri. She recorded it from 69 localities in 27 counties, based on museum specimens, written reports, and recently reported sightings gathered from a mail-survey (DeSanty-Combes 2001). Twenty-seven of these localities were reported from 1990-2001 and 16 occurred in 2001 alone (DeSanty-Combes 2001). At nearly $80 \%$ of sites visited by her in June 2001, most shared characteristics that included "wide grassy roadside ditches or brushy fence rows (with an embankment suitable for burrowing), tree rows providing an edge component, cropland, and grassland" (DeSanty-Combes 2001, p. 1). In the course of visiting sites, DeSanty-Combes discovered one $S$. franklinii roadkill (in approximately 25 hours and 1,192 miles of driving). One additional $S$. franklinii roadkill was reported in her 2001 mail survey (DeSanty-Combes 2001). Another state biologist trapped one adult male and one juvenile female in a 30-trap-day effort in July 2001 at a site where $S$. franklinii were observed earlier in the summer, but subsequent trapping at the location (90 additional trap-days) produced no additional animals (DeSantyCombes 2001).

DeSanty-Combes continued her survey efforts for S. franklinii in 2002. Another mail survey resulted in 32 more reported sightings, of which 29 were from new locations (DeSanty-Combes 2002). She visited many of these sites to verify the squirrel's presence. Because $S$. franklinii has been recorded from only 16 of 27 historically occupied counties since 1990, she proposed that further research be conducted to determine the ecological factors limiting the distribution of the species within Missouri. As a result of her recent findings, the status of $S$. franklinii in Missouri changed from S4 to S2S3, which indicates that the species is rare and may be locally imperiled (DeSanty-Combes 2002).

Nebraska. Warren $(1875$, p. 93) collected one S. franklinii "near the mouth of the Loup Fork of the Platte" where he found them "quite rare" 
in his explorations during 1855-1857. In contrast, Aughey (1880, p. 120) reported S. franklinii as "common on the prairies" of Nebraska. Perhaps, as was true elsewhere throughout its geographic range, the abundance of $S$. franklinii in Nebraska varied locally. A portion of a letter from Lawrence Bruner (a professor at the University of Nebraska), reprinted by Bailey (1893, p. 52), supported this view: "Franklin's Spermophile is quite common in some parts and rare in others." Swenk (1908, p.30) considered $S$. franklinii locally abundant and "very common in eastern Nebraska east of the $98^{\text {th }}$ meridian." First-hand accounts from U.S. Biological Survey reports (Table 8) provided more specific information about $S$. franklinii in Nebraska around the turn of the nineteenth century.

No detailed accounts from the first-half of the twentieth century address the habitat associations or local abundance of S. franklinii in Nebraska. Although during this time the species was of sufficient abundance and availability to serve as a study organism for Otis Wade, a professor at the University of Nebraska who published several works on hibernation in ground squirrels (Wade 1930, 1948, 1950; Wade and Gilbert 1940). Later, Jones (1964) summarized the status of $S$. franklinii in the state prior to 1960 . He considered it "typically an inhabitant of the tall-grass prairie of the eastern part of the state" (p. 124) and noted that burrow sites occurred in "tall grass, brush, or the wooded borders of grassy areas" (Jones 1964 , p. 125). As early as the 1960 s, he perceived a decline of the squirrel in the southeastern region of Nebraska and commented, "In my own experience, Franklin's ground squirrel was seen more frequently in the vicinity of Lincoln 15 years ago, even 10 years ago, than today" (Jones 1964, p. 125).

Haberman and Fleharty (1971, p. 77) found S. franklinii "common in low-lying areas near bridges and along road sides and railroad rightof-ways" in Boone County. The burrows of their study population were in stands of smooth brome (Bromus inermis) with an abundance of chokecherry (Prunus virginiana) bushes and wild plum (Prunus americana) thickets nearby (Haberman and Fleharty 1971). According to citizens of Boone County, in 1969 populations of $S$. franklinii were at a 20 -year high and now were occurring near buildings and hay bales on local farmsteads (Haberman and Fleharty 1971).

Data on S. franklinii in Nebraska were gleaned from two additional published sources. Pivorun and Sinnamon (1981), although they provided no specific locality, trapped $30 \mathrm{~S}$. franklinii in Nebraska in May 1978 for their study of blood coagulation in hibernating ground squirrels. This certainly indicates the presence of a sizeable local population, or populations, of $S$. franklinii in Nebraska at that time. Manning and Geluso (1989) reported a single sight record of $S$. franklinii from about $20 \mathrm{~km}$ east of the Halsey National Forest property, in central Nebraska. The animal was in tall grass along the road near the Middle Loup River (Manning and Geluso 1989).

North Dakota. Elliott Coues found S. franklinii abundant at Pembina, North Dakota, near the Canadian border prior to 1877 (Coues and Allen 1877). Years later they were still common at Pembina, according to Bailey (1888), who found them in brush, prairie meadows, and fields. At Devil's Lake in Ramsey County, he (Bailey 1888, p. 439) observed that they seemed "to prefer woods or low marshy and weedy land." He later added that, at Devil's Lake, "they were most common in the straggling groves of small trees a little back from the lake, and many of their burrows were placed under logs and stumps or between the roots of trees" (Bailey 1893, p. 51). A few years later, A.K. Fisher of the U.S. Biological Survey observed that the population at Devil's Lake had declined (see Table 9).

In the early 1900s in parts of eastern North Dakota, S. franklinii frequently was considered common or abundant and usually found associated with habitat that contained a woody component (Table 9). Bailey et al. (1914, p. 7) stated, "They are not generally distributed over the open prairie country, but depend on the cover of brush and timber, and in suitable areas become very numerous and extremely destructive." Bailey (1926) reiterated those thoughts more than a decade later. Agricultural practices certainly caused changes in local abundance of $S$. franklinii in North Dakota. In areas where they were once uncommon, they suddenly occurred in great numbers, only later to decline to the point of disappearance-certainly due in part to attempts to exterminate them as agricultural pests (Table 9). 
Since the early surveys, the literature concerning S. franklinii in North Dakota has dealt principally with the species as a predator of duck nests $-S$. franklinii is known to consume duck eggs (Sargeant et al. 1987, ChoromanskiNorris et al. 1989, Sargeant et al. 1993). One of these studies-Choromanski-Norris et al. (1989) (based on Choromanski-Norris 1983) resulted in the most carefully measured information on habitat use by $S$. franklinii within the state. They tracked S. franklinii within a waterfowl production area using radio-telemetry. In their study, conducted in Stutsman County in central North Dakota, the most intensively used portion of the study area was in, and in proximity to, a tree-belt that was composed principally of Russian olive (Elaeagnus angustifolia), chokecherry (Prunus virginiana), plum (Prunus spp.), red-osier dogwood (Cornus stolonifera), and lilac (Syringa spp.) (Choromanski-Norris et al. 1989). Because the tree-belt constituted approximately $1.5 \%$ of available habitat, its high use indicated a strong habitat preference by the squirrel (Choromanski-Norris et al. 1989).

Sargeant et al. (1993) found S. franklinii at seven of nine study sites in North Dakota (see Table 3). They considered it "scarce" at all locations except Sharon, where it was considered "uncommon" (Sargeant et al. 1993 and Table 3). All of the North Dakota study sites were included in the prairie zone of the Prairie Pothole region (Sargeant et al. 1993 and Table 3).

South Dakota. Four museum specimens (NMNH 14914, 21831, 192729, 192730) collected at Fort Sisseton in the northeastern part of South Dakota in 1887 comprise the earliest evidence of $S$. franklinii in the state. A few years later, in 1893, Bailey wrote that $S$. franklinii was, "Common at Scotland where one specimen was taken" and "said to be quite common at Running Water" (in lit, NHMH, Box 90, Folder 17). Both Scotland and Running Water are located in the southeast corner of South Dakota. Over and Churchill (1945) indicated that the range of $S$. franklinii did not extend much beyond the Missouri River and that, in the southeastern part of the state, "it frequents the highways and lives in the banks along the roadside" (p. 25). They reported that it "no doubt destroys many eggs and the young of ground nesting birds" (p. 25) and supported that statement with an account of a squirrel destroying two nests - one identified as quail, Colinus virginianus (Over and Churchill 1945). Findley (1956), Choate and Jones (1981), Sargeant et al. (1993), and Higgins et al. (2000) add little more to the account of $S$. franklinii in South Dakota. Findley recorded the species from Clay County, but provided no specific information about the specimen. Choate and Jones (1981) included S. franklinii in their account of mammals found in the state and remarked that the western limits of its distribution were poorly known. Sargeant et al. (1993) recorded S. franklinii from near Parkston, the only one of their three South Dakota study sites where the species was observed (see Table 3 ). Most recently, Higgins et al. (2000) provided a general account of the species within the state. They stated that, although found in brushy areas or along woodland edges, the squirrel favors areas of dense grass, such as may be found in tallgrass or mixed-grass prairies (Higgens $e t$ al. 2000).

Wisconsin. Strong (1883) provided the earliest record of $S$. franklinii from Wisconsin that I found. He reported it from the prairie regions, noted it frequently inhabited cultivated fields and did not occur as commonly as $S$. tridecemlineatus. Bailey (1893) found the northernmost records of $S$. franklinii in Wisconsin at Plover and Ripon - in central and south-central Wisconsin, respectively. It was rare at those localities (Bailey 1893). Snyder (1902) collected three specimens in Dodge County: one near some barns in 1891; a second which was dug from its burrow in an oat field in 1892; and a third in 1900 after it was observed running along a road bordered by fields of newly sown grain and clover. Snyder (1902) received reports of the commonness of $S$. franklinii in certain townships of Dodge County, but also mentioned his own difficulties in finding the species on a consistent basis.

Jackson (1908, p. 18) considered S. franklinii generally "rare in all sections of the state" but noted "careful observation will prove them quite common west from Rock County to the Mississippi River and north to Pepin County." He said they occurred in fields of growing grain and along fencerows and observed that they moved to areas of tall grasses when the grain fields were cut (Jackson 1908). He felt the shyness of the species contributed to the lack of information concerning it within Wisconsin Continued on page 31 
Table 9. Accounts of Franklin's ground squirrel, Spermophilus franklinii, in North Dakota from notes recorded by U.S. Biological Survey personnel contained in the archives at the NMNH.

\begin{tabular}{|c|c|c|c|}
\hline Locality & Habitat & Abundance & Source \\
\hline $\begin{array}{l}\text { Devils Lake, } \\
\text { Ramsey County }\end{array}$ & & $\begin{array}{l}\text { "Franklin's Spermophile was apparently } \\
\text { very rare as only one specimen was } \\
\text { secured. A few years since Mr. Bailey } \\
\text { found it common, but found Richardson's } \\
\text { Spermophile very rare, which species at the } \\
\text { present time is very abundant." }\end{array}$ & $\begin{array}{l}\text { A.K. Fisher } \\
1893 \\
\text { Box 79, } \\
\text { Folder } 16\end{array}$ \\
\hline
\end{tabular}

Lisbon, Ransom

County

LaMoure,

LaMoure

County

Grafton, Walsh

County

Walhalla,

Pembina County

Wales,

Cavalier County

Birchwood,

Rolette County

See information

in the account

within the

"Abundance"

section in this row.

Portland,

Traill County
"Said to be not common; I did not see any."

\author{
A.K. Fisher \\ 1893 \\ Box 79, \\ Folder 16
}

A.K. Fisher

1893

Box 79,

Folder 16

occidentalis along the banks of the James River."

"This Franklin's ground squirrel is also numerous at this locality."

H.V.Williams

1912

Box 80,

Folder 25

"inhabiting the timber and brushy districts. They live in holes usually at the foot of a tree or stump."

"This ground squirrel is also abundant thru this locality."

H.V. Williams

1912

Box 80 ,

Folder 25

H.V. Williams

1912

Box 80,

Folder 25

H.V. Williams

1912

Box 80,

Folder 25

H.V. Williams

1912

Canada the country is overrun with the

Franklin ground squirrel. They are the

thickest near Starkweather...A decrease in numbers was noticed after reaching Adams and very few were seen from there to Park River while none from Park River to Grafton."

"After reaching the delta saw no more of the Richardsons ground squirrel, its place being taken by the Franklin's and the Striped."
Box 80,

Folder 25

\section{A. Eastgate \\ 1912 \\ Box 79, \\ Folder 15}


Table 9 continued

$\begin{array}{llll}\text { Locality Habitat } & \text { Abundance } & \text { Source }\end{array}$

Valley City,

Barnes County

"all along the river and larger ravines where any small brush and tall weeds grow."

"common in [the] river valley."

A. Eastgate

1912

Box 79,

Folder 15

Kathryne,

Barnes County

Lisbon, Ransom

County

"Very common along the valley and on the higher prairie."

A. Eastgate

1912

Box 79,

Folder 15

"Very common all along the valley."

A. Eastgate

1912

Box 79,

Folder 15

Fairmount, Richland County

"They inhabit the ground chiefly along the course of the Bois de Sioux River where they make their burrows in the nettles."

"abundant throughout the southeastern part of the state."

H.H. Sheldon

"They are becoming a pest in this section Box 80, of the state and I was told by many farmers Folder 16 that three years ago they did not know such an animal existed and [they] have become more numerous each year."

Lidgerwood, "inhabiting grass bordering "Very abundant."

H.H. Sheldon

Richland County grain fields."

Box 80,

Folder 16

$\begin{array}{ll}\text { Oakes, Dickey } & \text { "along [the] James River } \\ \text { County } & \text { where the tall grass offers } \\ & \text { concealment for their burrows } \\ & \text { which in usually every case are } \\ & \text { adjacent to grain fields." }\end{array}$

“Abundant."

H.H. Sheldon

1915

Box 80,

Folder 16

Ellendale,

Dickey County

"These squirrels have never been

H.H. Sheldon common in this vicinity...However

1915

it does occur."

Box 80,

Folder 16

Wahpeton,

Richland County

"occurs in this locality."

R. Kellogg

1915

Box 80,

Folder 2

Grafton, Walsh " "several seen in hay field."

R. Kellogg

1915

Box 80,

Folder 2 
Table 9 continued

Locality
Drayton, Pembina
County

Manvel, Grand

Forks County

Larimore, Grand

Forks County

"Two were taken on the edge of a wheat field."
Abundance

"Does a great deal of damage to the growing corn."

R. Kellogg

1915

Box 80,

Folder 2

"Farmers here endeavor to kill these ground squirrels off as fast as they see them because of the damage they do."

R. Kellogg

1915

Box 80,

Folder 2

R. Kellogg

1915

Box 80,

Folder 2

"Common."

R. Kellogg

1915

Box 80,

Folder 2

R. Kellogg

1915

Box 80,

Folder 2

O.J. Murie

1919

Box 80,

Folder 13

Table 10. Tabulation of specific accounts of Franklin's ground squirrel, Spermophilus franklinii, reported in the text that address $S$. franklinii populations and habitat use. Refer to Appendix Table 1 to see the list of citations used to construct this table.

\begin{tabular}{|c|c|c|c|c|c|c|}
\hline \multicolumn{3}{|c|}{ Characterization of population(s) } & \multicolumn{3}{|c|}{ Characterization of habitat } & \multirow[b]{2}{*}{ Woodland } \\
\hline $\begin{array}{l}\text { Publication year } \\
\text { of citation }\end{array}$ & $\begin{array}{l}\text { Common, abundant, } \\
\text { increasing, or a pest }\end{array}$ & $\begin{array}{l}\text { Uncommon, rare, } \\
\text { or declining }\end{array}$ & $\begin{array}{l}\text { Fluctuating or variable } \\
\text { in occurrence }\end{array}$ & Prairie $^{1}$ & Savanna $^{2}$ & \\
\hline Pre - 1950 & 32 & 18 & 10 & 16 & 28 & 2 \\
\hline Post - 1950 & 8 & 22 & 9 & 19 & 31 & 0 \\
\hline Totals & 40 & 40 & 19 & 35 & 59 & 2 \\
\hline \multicolumn{7}{|c|}{$\begin{array}{l}l^{1}=\text { Habitat description includes no mention of woody vegetation, only grasses and forbs. } \\
{ }^{2}=\text { Habitat description includes mention of both grassy and woody vegetation. } \\
{ }^{3}=\text { Habitat description includes mention of only woody vegetation }\end{array}$} \\
\hline
\end{tabular}


(Jackson 1908). Hollister (1908) reiterated some of Jackson's points and added a few additional details that contribute to the picture of $S$. franklinii in Wisconsin. He found it "common in isolated colonies in various parts of Walworth County" (Hollister 1908, p. 139). The largest colonies occurred on the "Ridge Prairie" and on the border of the "Big Marsh" near Delavan. At Big Marsh he shot one out of a tamarack tree (Larix laricina) "from a considerable height," having mistaken it for a gray squirrel (Hollister 1908, p.139).

Schmidt (1931, p. 111) collected one $S$. franklinii that "was living in brush consisting of poplar, soft maple, and jack pine, in which there were a few open spaces grown up to sweet fern and blueberries" in western Clark County in 1927 or 1928 . He examined the stomach contents of that individual and found it contained 20\% "highbush blueberries", $30 \%$ "blueberries", and 50\% "white roots" (Schmidt 1931, p. 111).

The most extensive information concerning S. franklinii in Wisconsin is from Jackson (1961). About its habitat associations, in addition to the citations already referenced, he added: " sometimes [it is found] in fairly heavy woods, particularly of Norway or jack pine, if sufficient undercover of ferns, grass, or low shrubs is present; rarely in the vicinity of barns or farm houses" (Jackson 1961, p. 140). He considered the "sheltering cover of tall grass or other herbage.... necessary condition for its habitat" and noted "it is not found in closely grazed or mowed pastures, fields, lawns, or cemeteries where the striped ground squirrel might be common" (Jackson 1961, p. 140). Jackson (1961) said the species could not be considered common in Wisconsin, but added that it is probably more "plentiful than records indicate" (p. 140). Like many others, he commented on the variable nature of S. franklinii populations when he stated, "It may become common at times in isolated small colonies, but tends to shift its homesite and may be present one day, gone the next, and back again in a few weeks, another year, or several years" (Jackson 1961, p. 140).

Lewis and Rongstad (1992) gathered reports of 35 sightings of $S$. franklinii from 28 locations in 14 Wisconsin counties in 1985 and 1986. Reports revealed concentrations of squirrels in Douglas, Burnett, and Rusk counties in northwest Wisconsin, and in Waukesha,
Racine, and Kenosha counties in southeastern Wisconsin, as well as at scattered localities in a northwest band through the center of the state (Lewis and Rongstad 1992). In his thesis, Lewis (1988) suggested that populations of $S$. franklinii at Crex Meadows Wildlife Area in Burnett County and Bong Recreation Area in Racine County might serve as source populations for reintroductions elsewhere. However, I was unable to locate squirrels in brief searches at either Crex Meadows (visited in 1999) or at Bong (visited in both 2000 and 2001). Refuge personnel at Crex Meadows indicated that $S$. franklinii were fairly common $8-10$ years ago but have not been seen regularly since then (P. Petersen, pers. comm.).

Anthony (1999) initiated the Wisconsin Small Mammal Survey for his M.S. thesis. The effort involved coordinating volunteers to survey various grassland habitats in southern Wisconsin to establish base-line data and habitat preferences of small mammals. Anthony (1999) recorded $S$. franklinii from only 1 of 16 study sites in 24 trapping events spanning 1995-1997. The squirrel was found in August 1997 at Chiwaukee Prairie, located in the extreme southeast corner of the state (Anthony 1999).

\section{DISCUSSION}

Several generalizations can be made about $S$. franklinii based on the preceding accounts. First, throughout its geographic range, $S$. franklinii usually occurs in habitat that contains both grassy and woody components. Of 96 specific accounts, 59 clearly indicate that both grassy and woody vegetation were present in habitat occupied by S. franklinii (Table 10). Second, the squirrel frequently exhibits changes in local abundance. Lastly, according to the published literature since 1950, S. franklinii is considered less common in general (Table 10). More specifically it is encountered less frequently in the southern portion of its geographic range than in former times. Of 22 accounts published since 1950 that indicate $S$. franklinii is uncommon, rare, or declining (Table 10), 15 of these are from the four states (Indiana, Illinois, Missouri, and Kansas) that occupy the southernmost portion of $S$. franklinii's geographic range. (Refer to Appendix Table 1 for specific information on the citations used to construct Table 10.) Each 
of these generalizations will be expanded upon in the following paragraphs.

\section{Habitat}

Historical and natural associations. From the earliest accounts to the present, even prehistorically, S. franklinii most commonly has been found in habitat containing a mix of grassy and woody components. This mixture of vegetation occurs at the interface of many different types of woodland - both deciduous and coniferous - and grassland habitats. Woodland edges, grassy openings within woods, wooded valleys within grasslands, riparian corridors, and grasslands that include scattered trees and shrubs, all constitute habitat suitable for $S$. franklinii.

In the southern part of its geographic range, many have referred to $S$. franklinii as an animal of the tallgrass prairie (Van Petten and Schramm 1972, Krohne et al. 1973, Jones et al. 1983, Krohne and Schramm 1992, Benedict et al. 1996, Higgins et al. 2000, Pergams and Nyberg 2001). Because of this association, some have suggested a correlation between decreased availability of tallgrass prairie habitat-less than $4 \%$ of pre-European coverage is left (Samson and Knopf 1994) - and declining $S$. franklinii populations (Bowles 1981; Benedict et al. 1996; Pergams and Nyberg 2001, 2003). While it is true that there is considerable overlap between the geographic range of $S$. franklinii and the historic range of the tallgrass prairie environment (the foreststeppes and prairie ecoregion in Fig. 2), and while it is also true that the loss of tallgrass prairie habitat has undoubtedly negatively impacted S. franklinii, based on the review of the available literature I would contend that $S$. franklinii is not an animal that is strongly tied to tallgrass prairie habitat in the strictest sense. First, historically $S$. franklinii has occurred in nonprairie areas, particularly in the northern part of its range (Fig. 2). The northern exceptions aside, the fact that $S$. franklinii shares much of its distribution with the range of the former tallgrass prairie does not imply that tallgrass prairie is its focal habitat. Said another way, while $S$. franklinii could reasonably be described as an animal of the tallgrass prairie region, I feel that describing $S$. franklinii as an animal with a preference for tallgrass prairie habitat is much too restrictive. In describing $S$. franklinii habitat it is important to be cognizant of the effects of scale on perception. Although vegetation maps of the upper Midwest generally show two vegetation types, prairie and forest, a gradient exists between grasslands and woodlands where the habitats meld (Taft 1997). As Taft (1997) suggests, the portrayal of this sharp division is more a matter of convenience and is principally the result of the difficulty in mapping a habitat gradient. Unfortunately, this gradient that occurs at the interface of prairie and forest habitat - referred to as savanna, open woodland, or simply, savanna-like habitat (Taft 1997) - long has been ignored as an ecological community in North America.

To return to the issue of $S$. franklinii and tallgrass prairie habitat, Sargeant et al. (1993, p. 30) offered this view: "Little is known about the abundance of this species before settlement or about population trends after settlement. However, because of its specific habitat requirements, Franklin's ground squirrels probably were scarce or absent throughout the prairie before settlement, except in locations with brush, and probably were numerous in the aspen parkland." Indeed, Sargeant et al. (1993) found $S$. franklinii significantly more common at study sites within the aspen parkland zone than at those within the prairie zone. Although the comments of Sargeant et al. (1993) may suggest that $S$. franklinii historically was less common in the southern part of its geographic range where aspen parkland was absent, Taft (1997) clearly illustrates that other habitat was available for $S$. franklinii in the south in the form of oak-savannas. These oak-savannas were prevalent throughout Indiana, Illinois, Missouri, and much of Iowa and Wisconsin in presettlement times (Fig. 2.1 in Taft 1997). This understanding of the distribution of savanna-like habitat is reflected in Bailey's (1998) map of North American ecoregions, which includes the 'forest-steppe and prairie' ecoregion where tallgrass prairie is typically found (Fig. 2). Finally, while all evidence suggests that $S$. franklinii is most frequently associated with habitat that contains both grassy and woody components, it can occur in habitat that is dominated by grasses and forbs. However, based on my review of the data, I agree with Taft (1997) who included S. franklinii in a list of animals found in midwestern savanna-like habitats. Clearly, S. franklinii is described best as a species with an affinity for savanna-like habitats. 
Agricultural associations. In addition to its use of natural, savanna-like habitats, many of the early accounts of $S$. franklinii, even accounts of prehistoric occurrence, indicate the squirrel's use of agricultural lands. From a distributional perspective, the clearing of forested areas for agriculture, which resulted in increased contact between grassland and woodland environments, allowed $S$. franklinii to expand its geographic range in some regions - particularly in the east (DeVos 1964). Agricultural modification of the land resulted in S. franklinii moving east into Ontario (Snyder 1938) and northeast in Minnesota (Hazard 1982; Robins 1970-1971), and allowed overall range expansions in both Iowa (Scott 1937) and Indiana (Lyon 1932).

Agriculture also affected the local abundance of S. franklinii. Because S. franklinii consumed newly planted corn and other grains, early agricultural practices provided an abundant source of food in close proximity to favorable habitat. Increased abundance of S. franklinii populations as a result of early agricultural practices were hinted at by Spurrell (1917, p. 283) who reported from Iowa, "This species was not as common in early days as it is now." The association of $S$. franklinii with agricultural lands also has had negative consequences for the species. As indicated in the accounts, when $S$. franklinii became noticeably numerous in agricultural areas, efforts were made either to eliminate them entirely, or at least to significantly reduce their numbers. This scenario even may have occurred at prehistoric agricultural settlements (Rhodes and Semken 1986).

Right-of-ways. Today, S. franklinii is frequently found along roadside or railroad right-ofways, particularly in the southern portions of its geographic range (Haberman and Fleharty 1971; Gray 1972; Ellis 1982; Mumford and Whitaker 1982; Benjamin 1991; Johnson and Choromanski-Norris 1992; Lotter 1994; Hoffmann 1999; DeSanty-Combes 2001, 2002). Ellis (1982) concisely stated the reason for the high frequency of use of these right-of-ways by the squirrels in the southern portion of their geographic range: simply put, often right-ofways represent the only available patches of habitat that meet the squirrel's needs. Gray (1972) echoed this sentiment for his area of Illinois when he stated that idle land was limited to streambanks, roadsides, railroads, and small woodlands along streams, the remainder of the land being utilized predominantly for intensive agriculture.

Modern agricultural practices in much of the midwestern U.S. maximize use of all available lands, thus fields are often plowed to fences or roads. Field-edges and fencerows that once provided valuable habitat for many different species of wildlife now, typically, are non-existent or quite "clean." In contrast, although typically roadside right-of-ways receive at least some level of mowing during summer months, in the absence of roadwork (such as lane widening) they are relatively undisturbed and often form ideal habitat for $S$. franklinii. This is particularly true of rural roads that often contain a mixture of grasses and forbs that grow unhindered throughout much of the summer, frequently complimented by shrub thickets and scattered trees. These factors, certainly apparent to Platt et al. (1973) in Kansas, led them to recommend that farmers leave native vegetation around field-edges and that the department of roads restrict mowing along roadside right-of-ways in order to increase $S$. franklinii habitat. Like roadside right-of-ways, railroad right-of-ways may serve as excellent habitat for $S$. franklinii in the lower Midwest. These areas, particularly when no longer in use and thus left undisturbed, result in a diverse mix of thick vegetation including grasses, shrubs, and trees in various stages of growth. Right-ofways are almost certainly of less importance for the persistence of $S$. franklinii in the northern part of its geographic range where woodland edges and openings and aspen-parkland habitat remain relatively common.

\section{Influences on Abundance}

Although S. franklinii certainly appears to be capable of persisting at a site for many decades, especially large sites such as Delta Marsh in Manitoba (Sowls 1948, Tasmitt 1962, pers. obs. 2000, Hare 2004), more commonly the occurrence of the species at a specific location is highly variable. Several authors, reporting from Illinois (Kennicott 1857) and Wisconsin (Jackson 1961) in the south to Saskatchewan (Soper 1951, 1961b) in the north, have indicated that the squirrel may be present at a locality for some time - weeks, months, or even years - and then suddenly disappear. (See also Table 10 and the Appendix Table 1.) In the following paragraphs I convey how population 
cycles, disturbance, and dispersal activities all may affect the squirrel's local abundance. Additionally, serving as the backdrop for these processes, I also suggest that $S$. franklinii's primary use of savanna-like habitat has consequences for the persistence of its populations at local sites.

\section{Population cycles and fluctuations. As}

indicated in the accounts, several authors have reported population fluctuations or cycles within S. franklinii (Sowls 1948, Haggerty 1968, Haberman and Fleharty 1971, Banfield 1974 Erlien and Tester 1984, Keith and Cary 1991). In some cases, cyclic lows reduce populations to the point where they disappear from the immediate area for a time (Erlien and Tester 1984), or are nearly brought to that point (Keith and Cary 1991). In those scenarios, the local site is repopulated, at least in part, by dispersers from nearby populations (Haggerty 1968, Erlien and Tester 1984). The factors responsible for these population fluctuations or cycles within $S$. franklinii remain unclear, but have been linked to snowshoe hare cycles with the squirrels serving as an alternate prey source for the hare's predators (Erlien and Tester 1984, Keith and Cary 1991). Although these reported population cycles within S. franklinii are limited to the northern part of the squirrel's geographic range (Minnesota, Manitoba, Alberta), where it overlaps with the distribution of the hare and thus lends some support to this hypothesis, irregular population peaks have been reported in Nebraska (Haberman and Fleharty 1971), outside the range of the hare. More long-term monitoring is needed to determine factors contributing to population fluctuations of S. franklinii.

Disturbance. The most obvious types of disturbance to populations of $S$. franklinii historically were attempts to exterminate them from a local area. Programs to eradicate squirrels were common around the turn of the nineteenth century (Bailey 1893) in the United States, and certainly resulted in dramatic fluctuations in local populations.

Disturbance of the squirrel's habitat also may cause their sudden departure from an area. Plowing of agricultural fields, which destroys burrows, will certainly cause any squirrels with burrows within the plowed field to leave - at least for a time. However, as Spurrell (1917) indicated, haying or mowing of tall grass also will cause squirrels to relocate to more favorable habitat. Loss of ground cover due to fire-prescribed or otherwise, is likely to cause $S$. franklinii to avoid the area until it is revegetated. I will discuss the impact of disturbance on the persistence of S. franklinii populations in greater detail in the "Conservation and Threats" section that follows.

Dispersal. Juvenile and male-biased dispersal is common in most ground squirrels (Holekamp 1984). Haggerty (1968), Ellis (1982), and Martin and Heske (2005) provided evidence that dispersal of $S$. franklinii, especially in juvenile animals, is probably quite common and accounts for both individual gains (through immigration to the site via dispersal) and losses (through emigration from the site via dispersal) in the local squirrel population. Population size and longevity in S. franklinii certainly is affected by dispersal activities, as it is in other animal populations (in Holekamp 1984). In the case of $S$. franklinii, because the squirrel lives in an increasingly fragmented environment-particularly in the southeastern portion of its geographic range, the survival of dispersing squirrels may be significantly lower than in historic times. Certainly, throughout much of the squirrel's geographic range, there are now greater distances separating areas of suitable habitat. Furthermore, the matrix between suitable areas of occupation is increasingly inhospitable to $S$. franklinii, as it has come to be dominated by agricultural monoculture, sterile suburban and urban landscapes, and everywhere a network of roadways. The failure of dispersers to encounter established populations may be a primary cause of the regional decline in S. franklinii in the southern portion of its geographic range. In effect, S. franklinii may exist as a dysfunctional metapopulation (Levins 1970) in this region where isolated populations (i.e., subpopulations) experience greater losses due to emigration than gains from immigration.

Effects of habitat. As already detailed, $S$. franklinii principally occupies savanna-like habitat. This habitat, by its very nature of being a composite of grasslands and woodlands, is habitat that is in flux (Skarpe 1992, Taft 1997); it moves from being dominated by one of these components to the other. In a simplistic sense, in the absence of disturbance (e.g., fire, wind- 
storm, drought, or human habitat alteration) a savanna-like habitat will eventually come to be dominated by woodland habitat. Conversely, in the aftermath of disturbance, grassland habitat will dominate. In the case of S. franklinii, an occupied site-more specifically, a given habitat patch - may always be fluctuating in size as it responds to disturbance, or lack thereof. This obviously will have a bearing on the population dynamics within that habitat patch. If, for example, a given habitat patch becomes less favorable over time due to changes in vegetation, increased competition within the patch and increased rates of dispersal may result in a population decline at that site. This hypothesis - that the dynamic nature of savanna-like habitat occupied by $S$. franklinii directly influences its population dynamics - needs to be tested to see if it offers a plausible explanation for the variable nature of $S$. franklinii populations.

\section{Conservation and Threats}

It is apparent that $S$. franklinii has experienced declining populations in parts of its geographic range, particularly in the south (Platt et al. 1973; Bowles 1981; Johnson and Choromanski-Norris 1992; Lotter 1994; Anthony 1999; DeSanty-Combes 2002; Martin et al. 2003; Pergams and Nyberg 2001, 2003). The cause for these declines certainly includes human induced changes of local habitat, but may include other factors as well. In the following paragraphs, I will review known factors responsible for the decline of $S$. franklinii populations, speculate on additional factors, and discuss the current conservation concern for the species.

Habitat loss and disturbance. Although $S$. franklinii is not dependent on native or pristine habitat - the squirrel has occupied sites around landfills (Murie 1973) and in the midst of industrial settings (Lotter 1994) - loss of habitat nevertheless has contributed to its decline. As discussed earlier, in the southern portion of the squirrel's geographic range the availability of appropriate habitat is limited primarily to roadside and railroad right-of-ways. It is not surprising, then, to find that $S$. franklinii populations have declined in these regions of decreased habitat availability. Furthermore, while right-of-ways can provide suitable habitat for S. franklinii, they are often subject to disturbances that limit their usefulness. Frequent mowing and, more dramatically, lane-widening projects or track removal, may alter a site to the point that it is unsuitable for years to come Lotter (1994).
Not surprisingly, current $S$. franklinii habitat also is being lost through the construction of subdivisions, as documented by Lotter (1994). As urban sprawl continues to annex wildlife habitat, seemingly unabated, this trend will continue. To date the impacts of urbanization and sprawl have been greatest in the southeastern portion of the geographic range of $S$. franklinii where human populations are highest and where squirrel populations are of greatest conservation concern.

The connectedness of $S$. franklinii populations certainly contributes to the ability of the squirrel to recover from disturbances, whether human induced or otherwise. Erlien and Tester (1984) felt that when their study population of S. franklinii dropped to zero in 1965 and 1973 , the site was likely repopulated from another population located within $1.5 \mathrm{~km}$. Therefore, if distances that prohibit successful dispersal separate $S$. franklinii populations, then the prolonged existence of small populations - susceptible to various disturbances and other stochastic events - is undoubtedly tenuous. As already suggested, a metapopulation structure with declining subpopulations may aptly describe the existence of $S$. franklinii in portions of its geographic range.

Conservation status. In Indiana, where the distribution of $S$. franklinii has diminished to levels that warranted the listing of the species as "Endangered," the ecological importance of this decline may not be as significant as elsewhere in the species' geographic range. Although Lotter (1994) reported a continued reduction in S. franklinii populations since Johnson and Choromanski-Norris (1992), she still found the squirrel at eight sites in three counties, whereas Bailey (1893) reported $S$. franklinii from only two sites in extreme western Indiana. In short, it is likely that $S$. franklinii expanded its range in Indiana as a result of early agricultural practices and subsequently has declined as a result of habitat loss. The continued decline of the species in Indiana almost certainly is reflective of a general trend of increasing urbanization with concomitant habitat loss - especially in the heavily populated northwest corner of the state. These changes of the Indiana landscape should be of ecological concern, because they will affect many of the state's native organisms. However, in regard to $S$. franklinii in Indiana, the species might best be considered rare in the state-as are many other species at the periphery of their geographic ranges. 
Elsewhere in the southern portion of its geographic range, particularly in Illinois, Iowa, Kansas, and Missouri, S. franklinii populations may be occurring well below historic levels. Unfortunately, difficulties in detecting the presence of $S$. franklinii, coupled with its patchy distribution and irregular patterns of occurrence, make surveying for the species challenging and assessing declines even more problematic. With the exceptions of Illinois and Missouri, both of which have been surveyed intensely and systematically for $S$. franklinii in recent years (Hoffmann 1999; DeSanty-Combes 2001, 2002; Martin et al. 2003), declines in S. franklinii populations elsewhere in the south remain circumstantial, but quite likely. In my own limited efforts, I failed to locate any extant populations of $S$. franklinii in Iowa or Kansas, nor was I able to ascertain the existence of active populations residing within these states from regional biologists.

As I detailed in earlier sections, the availability of appropriate habitat certainly is most limited in the southern portion of the squirrel's geographic range where land use is most intense. In these areas where $S$. franklinii is limited in occurrence primarily to roadside and railroad right-of-ways, the species is extremely susceptible to additional disturbances. The conservation concern that has developed for $S$. franklinii in Illinois is certainly warranted, as it should be in Iowa, Kansas, and Missouri, at least until further data suggest otherwise.

Elsewhere, particularly in parts of Minnesota, North Dakota, Manitoba, and Saskatchewan, the region where $S$. franklinii historically has been common, the same remains true today. In appropriate locations, $S$. franklinii currently ranges from common to abundant in this region, a fact I verified through personal experience in May and June 2000. The greater prevalence of savanna-like habitat in the northern part of the squirrel's range undoubtedly contributes to its commonness in this region, as alluded to earlier by Sargeant et al. (1993). Loss of $S$. franklinii habitat as a result of human activity is also certainly less in the northern portion of the squirrel's geographic range, which is populated at lower human densities.

\section{CONCLUSIONS}

S. franklinii is a species that most frequently is associated with habitat characterized by a mix- ture of grassy and woody vegetation, that is, savanna-like or parkland habitat. The species has had an affinity for this type of habitat throughout its geographic range in recent, historic, and even prehistoric times. As a result of its association with agricultural lands, $S$. franklinii has expanded its geographic range in some areas but also has been subject to eradication programs that have resulted in its local extirpation. Populations of $S$. franklinii are subject to marked fluctuations, the reasons for these being not entirely clear, but which probably are influenced by local disturbances in addition to regular dispersal events. In the southern part of its geographic range, S. franklinii is limited in its occurrence principally to roadside and railroad right-of-ways as a result of a lack of other suitable habitat. In these southern regions, $S$. franklinii is justifiably of conservation concern. I suggest that more detailed surveys for the species (such as those that have recently occurred in Illinois and Missouri) take place in Iowa and Kansas.

\section{ACKNOWLEDGMENTS}

I am greatly thankful for the assistance of the many curators and collections managers that offered me aid during my on-site visits to museums, and that processed loans of museum specimens. Every museum I utilized is individually named in the Appendix. I also thank the archive staff at the Smithsonian's National Museum of Natural History for their assistance during my visit. I am grateful for the guidance provided by my doctoral committee, including Dr. Gwen Bachman, Dr. Patricia Freeman, Dr. Guillermo Ortí, Dr. Edward J. Peters, and particularly Dr. Hugh Genoways, who served as my academic advisor throughout my doctoral program. Special thanks to two anonymous reviewers and to Dr. Edward J. Heske and Dr. Oliver R. W. Pergams for their comments and suggestions on this manuscript. My wife, Dr. Erin Huebschman, deserves special thanks for her assistance with many aspects of this project. Financial support for this research was provided in part by the following sources: Center for Great Plains Studies, American Museum of Natural History, Theodore Roosevelt Memorial Funds, University of Nebraska-Lincoln Initiative in Ecology and Evolutionary Biology, and the Warren F. and Edith R. Day Dissertation Travel Funds. 


\section{LITERATURE CITED}

Allen, J.A. 1871. Notes on the mammals of Iowa. Proceedings of the Boston Society of Natural History 13:178-194.

Anderson, E.P. 1951. The mammals of Fulton County, Illinois. Bulletin of the Chicago Academy of Sciences 9:153-188.

Andersen, K.W., and E.D. Fleharty. 1967. Mammalian distribution within biotic communities of northeastern Jewell County, Kansas. Fort Hays Studies (n.s.), Science Series 6:1-45.

Anthony, N. 1999. The Wisconsin small mammal survey: a volunteer-based small mammal survey program for native grassland preserves in southern Wisconsin. M.S. thesis. University of Wisconsin-Madison. $127 \mathrm{pp}$.

Aughey, S. 1880. Sketches of the physical geography and geology of Nebraska. Daily Republican Book and Job Office, Omaha. 326 pp.

Bailey, R.G. 1998. Ecoregions map of North America: explanatory note. Miscellaneous Publication No. 1548, USDA Forest Service, Washington, D. C. 10 pp.

Bailey, V. 1888. Report on some of the results of a trip through parts of Minnesota and Dakota. Pages 426-454 in Report of the Commissioner of Agriculture, 1887. Government Printing Office, Washington. 724 pp.

Bailey, V. 1893. The prairie ground squirrels or spermophiles of the Mississippi Valley. U. S. Department of Agriculture, Division of Ornithology and Mammalogy, Bulletin No. 4. Government Printing Office, Washington. 69 pp.

Bailey, V., W.B. Bell, and M.A. Brannon. 1914. Preliminary report on the mammals of North Dakota. North Dakota Agricultural Experiment Station Circular 3. 20 pp.
Bailey, V. 1926. A biological survey of North Dakota. North American Fauna 49:1-226.

Banfield, A.W.F. 1974. The mammals of Canada. University of Toronto Press, Toronto. $438 \mathrm{pp}$.

Beck, W.H. 1958. A guide to Saskatchewan mammals. Special Publication No. 1, Saskatchewan Natural History Soceiety, Regina. $52 \mathrm{pp}$.

Bee, J.W., G.E. Glass, R.S. Hoffmann, and R.R. Patterson. 1981. Mammals in Kansas. University of Kansas Museum of Natural History, Public Education Series No. 7. Lawrence. 300 pp.

Benedict, R.A., P.W. Freeman, and H.H. Genoways. 1996. Prairie legacies-mammals. Pages 149-166 in F.B. Samson and F.L. Knopf, eds. Prairie conservation: preserving North America's most endangered ecosystem. Island Press, Washington, D.C. 340 pp.

Benjamin, P.M. 1991. The ecology of Franklin's ground squirrel in Indiana. M.S. thesis. Indiana State University, Terre Haute. 68 pp.

Bird, R.D. 1927. A preliminary ecological survey of the district surrounding the entomological station at Treesbank, Manitoba. Ecology 8:207-220.

Black, J.D. 1937. Mammals of Kansas. Kansas State Board of Agriculture, 30th Biennial Report 35:116-217.

Bowles, J.B. 1975. Distribution and biogeography of mammals of Iowa. Special Publication of the Museum, Texas Tech University 9:1-184.

Bowles, J.B. 1981. Iowa's mammal fauna: an era of decline. Proceedings of the Iowa Academy of Sciences 88:38-42.

Brumwell, M.J. 1951. An ecological survey of the Fort Leavenworth Military Reservation. American Midland Naturalist 45:187-231. 
Burachynsky, V.I., and T.D. Galloway. 1985. Seasonal dynamics and distribution of American dog tick, Dermacentor variablilis (Say), larvae and nymphs at Birds Hill Park, Manitoba. Canadian Journal of Zoology 63:2748 2755.

Choate, J.R., and J.K. Jones, Jr. 1981. Provisional checklist of mammals of South Dakota. Prairie Naturalist 13:65-77.

Choromanski-Norris, J.F. 1983. The ecology of the Franklin's ground squirrel in North Dakota. M.S. thesis. University of Missouri, Columbia. 64 pp.

Choromanski-Norris, J.F., K. Fritzell, and A.B. Sargeant. 1989. Movements and habitat use of Franklin's ground squirrels in duck-nesting habitat. Journal of Wildlife Management 53:324-331.

Clarke, R.F., J. Breukelman, and T.F. Andrews. 1958. An annotated list of the vertebrates of Lyon County, Kansas. Transactions of the Kansas Academy of Science 61:165-184.

Cockrum, E.L. 1952. Mammals of Kansas. University of Kansas Publications, Museum of Natural History 7:1-303.

Cory, C.B. 1912. The mammals of Illinois and Wisconsin. Field Museum of Natural History, Publication 153. Zoölogical Series, Volume XI. Chicago. 502 pp.

Coues, E., and J.A. Allen. 1877. Monographs of North American Rodentia. Report of the United States Geological Survey of the Territories. Volume. 11. $1091 \mathrm{pp}$.

Criddle, S. 1929. An annotated list of the mammals of Aweme, Manitoba. The Canadian Field-Naturalist 43:155-159.

Dalquest, W.W., and J.A. Baskin. 1992. Mammals of the Elm Creek local fauna, Late Pleistocene of Beaver County, Oklahoma. American Midland Naturalist 127:13-20.
Davis, L.C. 1987. Late Pleistocene/Holocene environmental changes in the central plains of the United States: the mammalian record. Pages 88-143 in R.W. Graham, H.A. Semken, Jr., and M.A. Graham, eds. Late Quaternary mammalian biogeography and environments of the Great Plains and prairies. Illinois State Museum, Scientific Papers, Vol. 22. Springfield. $491 \mathrm{pp}$.

DeSanty-Combes, J. 2001. Report of the known distribution of the Franklin's ground squirrel (Spermophilus franklinii) in Missouri. Unpublished report of the Missouri Department of Conservation. 9 pp. + XI appendices.

DeSanty-Combes, J. 2002. Final report for 2002 Franklin's ground squirrel survey in north Missouri. Unpublished report of the Missouri Department of Conservation. 8 pp. plus VI appendices.

DeVos, A. 1964. Range changes of mammals in the Great Lakes region. American Midland Naturalist 71:210-231.

Dobbyn, J. 1994. Atlas of the mammals of Ontario. Federation of Ontario Naturalists. Don Mills, Ontario. 119 pp.

Durham, P.J.K., F. A. Leighton, and G. A. Wobeser. 1988. An adenovirus infection of the kidney of Franklin's ground squirrels (Spermophilus franklinii) in Saskatchewan, Canada. Journal of Wildlife Diseases 24:636-641.

Ellis, L.S. 1982. Life-history studies of Franklin's ground squirrel, Spermophilus franklinii, in Missouri. Report to Missouri Department of Conservation. Northeast Missouri State University, Kirksville. 50 pp.

Erlien, D.A., and J.R. Tester. 1984. Population ecology of sciurids in northwestern Minnesota. The Canadian Field-Naturalist 98:1-6.

Errington, P.L. 1937. Summer food habits of the badger in northwestern Iowa. Journal of Mammalogy 18:213-216. 
Eshelman, R.E., and C.W. Hibbard. 1981. Nash local fauna (Pleistocene: Aftonian) of Meade County, Kansas. Contributions from the Museum of Paleontology, The University of Michigan 25:317-326.

Findley, J.S. 1956. Mammals of Clay County, South Dakota. University of South Dakota, Publications in Biology 1:1-45.

Gabrielson, I.N. 1921. Notes on the mammals observed in Marshall County, Iowa. Proceedings of the Iowa Academy of Science 28:147-149.

Gray, W.C. 1972. Social behavior and population dynamics of the Franklin ground squirrel, Citellus franklinii (Sabine). M.S. thesis. Illinois State University, Normal. 49 pp.

Green, H.U. 1932. Mammals of the Riding Mountain National Park, Manitoba. Canadian Field-Naturalist 46:149-152.

Griffin, D.R. 1989. Mammalian fossils from beneath the Patterson Ranch Pearlette volcanic ash in the Seymour Formation, Knox County, Texas. The Texas Journal of Science 41:277287.

Gunderson, H.L., and J.R. Beer. 1953. The mammals of Minnesota. The University of Minnesota Press, Minneapolis. 190 pp.

Haberman, C.G., and E.D. Fleharty. 1971. Natural history notes on Franklin's ground squirrel in Boone County, Nebraska. Transactions of the Kansas Academy of Science 74:76-80

Hafner, M.S., W.L. Gannon, J. Salazar-Bravo, and S.T. Alvarez-Castañeda. 1997. Mammal collections in the western hemisphere. American Society of Mammalogists. Allen Press, Lawrence, Kansas. 93 pp.

Haggerty, S.M. 1968. The ecology of the Franklin's ground squirrel (Citellus franklinii) at Itasca State Park, Minnesota. M.S. thesis. University of Minnesota, Minneapolis-St. Paul. $98 \mathrm{pp}$.
Hahn, W.L. 1909. The mammals of Indiana. Indiana Department of Geology and Natural Resources, 33rd Annual Report, Indianapolis 417-663.

Hall, E.R. 1955. Handbook of mammals of Kansas. University of Kansas Museum of Natural History, Miscellaneous Publication 7:1-303.

Hall, E.R., and K.R. Kelson. 1959. The mammals of North America. Volume I. The Ronald Press Company, New York. 546 pp +76 index pp.

Hare, J.F. 2004. Kin discrimination by asocial Franklin's ground squirrels (Spermophilus franklinii): is there a relationship between kin discrimination and ground squirrel sociality? Ethology Ecology and Evolution 16:157-169.

Hazard, E.B. 1982. The mammals of Minnesota. University of Minnesota Press, Minneapolis. $280 \mathrm{pp}$.

Herrick, C.L. 1892. The mammals of Minnesota. Geological and Natural History Survey of Minnesota Bulletin 7:1-299.

Hibbard, C.W., and W.W. Dalquest. 1966. Fossils from the Seymour Formation of Knox and Baylor counties, Texas, and their bearing on the Late Kansan climate of that region. Contributions from the Museum of Paleontology $21: 1-66$.

Higgins, K.F., E.D. Stukel, J.M. Goulet, and D.C. Backlund. 2000. Wild mammals of South Dakota. South Dakota Department of Game, Fish and Parks, Pierre. 278 pp.

Hilton, D.F.J., and J.L. Mahrt. 1971. Ectoparasites from three species of Spermophilus (Rodentia: Sciuridae) in Alberta. Canadian Journal of Zoology 49:1501-1504.

Hilton, D.F.J., and J.L. Mahrt. 1972. Prevalence of Trypanosoma otospermophili (Protozoa: Trypanosomatidae) in five species of Spermophilus (Rodentia: Sciuridae). Parasitology 65:427-432. 
Hoffman, J E. 1999. Franklin's ground squirrel: an increasingly rare prairie mammal. Illinois Natural History Survey Reports 355:1-2.

Hoffmeister, D.F. 1989. Mammals of Illinois. University of Illinois Press, Chicago. 348 pp.

Hoffmeister, D.F., and C.O. Mohr. 1957. Fieldbook of Illinois mammals. Manual 4. Natural History Survey Division, Urbana. 233 pp.

Holekamp, K.E. 1984. Dispersal in grounddwelling Sciurids. Pages 297-320 in J.O. Murie and G.R. Michener, eds. The biology of ground-dwelling squirrels. University of Nebraska Press, Lincoln. 459 pp.

Hollister, N. 1908. Notes on Wisconsin mammals. Bulletin of the Wisconsin Natural History Society 6:137-142.

Iverson, S.L., and B.N. Turner. 1972. Natural history of a Manitoba population of Franklin's ground squirrels. Canadian Field-Naturalist 86:145-149.

Jackson, H.H.T. 1908. A preliminary list of Wisconsin mammals. Bulletin of the Wisconsin Natural History Society 6:13-34.

Jackson, H.H.T. 1961. Mammals of Wisconsin. The University of Wisconsin Press, Madison. 504 pp.

Johnson, A.M. 1922. An observation on the carnivorous propensities of the gray gopher. Journal of Mammalogy 3:187.

Johnson, C.E. 1930. Recollections of the mammals of northwestern Minnesota. Journal of Mammalogy 11:435-452.

Johnson, S.A., and J. Choromanski-Norris. 1992. Reduction in the eastern limit of the range of the Franklin's ground squirrel (Spermophilus franklinii). American Midland Naturalist 128:325-331.
Jones, J.K., Jr. 1964. Distribution and taxonomy of mammals of Nebraska. University of Kansas Publications, Museum of Natural History 16:1-356.

Jones, J.K., Jr., D.M. Armstrong, and J.R. Choate. 1985. Guide to mammals of the plains states. University of Nebraska Press, Lincoln. $371 \mathrm{pp}$.

Jones, J.K., Jr., D.M. Armstrong, R.S. Hoffmann, and C. Jones. 1983. Mammals of the northern Great Plains. University of Nebraska Press, Lincoln. 379 pp.

Keith, L.B., and J.R. Cary. 1991. Mustelid, squirrel, and porcupine population trends during a snowshoe hare cycle. Journal of Mammalogy 72:373-378.

Keith, L.B., and E.C. Meslow. 1966. Animals using runways in common with snowshoe hares. Journal of Mammalogy 47:541.

Kellogg, R. 1915. The mammals of Kansas with notes on their distribution, habits, life histories and economic importance. M.A. Thesis. University of Kansas, Lawrence. 318 pp.

Kennicott, R. 1855. Catalogue of animals observed in Cook County, Illinois. Transactions of the Illinois State Agricultural Society 1:577-595.

Kennicott, R. 1857. The quadrupeds of Illinois, injurious and beneficial to the farmer. Transactions of the Illinois State Agricultural Society 2:615-684.

Kirkpatrick, C.M., and C.H. Conaway. 1948. Some notes on Indiana mammals. American Midland Naturalist 39:128-136.

Knox, M V.B. 1875. Kansas mammalia. Transactions of the Kansas Academy of Science 4:19-22.

Krohne, D.T., and P. Schramm. 1992. Hibernation and life history of the Franklin's ground squirrel (Spermophilus franklinii) in a restored 
prairie. Pages 71-74 in R.G. Wickett, P.D. Lewis, A. Woodliffe, and P. Pratt, eds. Proceedings of the Thirteenth North American Prairie Conference. Department of Parks and Recreation, Windsor, Ontario, Canada. 272 pp.

Krohne, D.T.,J. Hauffe, and P. Schramm. 1973. Radio-tracking the Franklin's ground squirrel in a restored prairie. Pages 84-88 in L.C. Hulbert, ed. Third Midwest Prairie Conference Proceedings. Kansas State University, Manhattan, Kansas. 91 pp.

Lantz, D.E. 1905. A list of Kansas mammals. Transactions of the Kansas Academy of Science 19:171-178.

Leighton, F.A., and G. Wobeser. 1978. The prevalence of adiaspiromycosis in three sympatric species of ground squirrels. Journal of Wildlife Diseases 14:362-365.

Levins, R. 1970. Extinction. Pages 75-107 in M. Gerstenhaber,ed. Some mathematical questions in biology. Lecture notes on mathematics in the life sciences. The American Mathematical Society, Providence, Rhode Island.

Lewis, T.L. 1988. Distribution and population dynamics of the Franklin's ground squirrel. M.S. thesis, University of Wisconsin-Madison. $86 \mathrm{pp}$.

Lewis, T.L., and O.J. Rongstad. 1992. The distribution of Franklin's ground squirrel in Wisconsin and Illinois. Transactions of the Wisconsin Academy of Sciences Arts and Letters 80:57-62.

Linsdale, J. 1928. Mammals of a small area along the Missouri River. Journal of Mammalogy 9:140-146.

Lotter, D.M. 1994. Distribution of Franklin's ground squirrel (Spermophilus franklinii) in Indiana. Report for the Department of Forestry and Natural Resources, Purdue University, West Lafayette, Indiana. 13 pp.
Lynch, G.M. 1972. Effect of strychnine control on nest predators of dabbling ducks. Journal of Wildlife Management 36:436-440.

Lyon, M.W., Jr. 1932. Franklin's ground squirrel and its distribution in Indiana. American

Midland Naturalist 13:16-21.

Lyon, M.W., Jr. 1936. Mammals of Indiana. American Midland Naturalist 17:1-384.

Manning, W.R., and K.N. Geluso. 1989.

Habitat utilization of mammals in a man-made forest in the sandhill region of Nebraska. Occasional Papers of the Museum, Texas Tech University 131:1-34.

Martin, J.M., and E.J. Heske. 2004. Cover and soil drainage influence burrow location of Franklin's ground squirrel (Spermophilus franklinii) in Champaign County, Illinois. Transactions of the Illinois State Academy of Science 97:227-233.

Martin, J.M., and E.J. Heske. 2005. Juvenile dispersal of Franklin's ground squirrel (Spermophilus franklinii) from a prairie "island." American Midland Naturalist 153:444-449.

Martin, J.M., E J. Heske, and J.E. Hofmann. 2003. Franklin's ground squirrel (Spermophilus franklinii) in Illinois: a declining prairie mammal? American Midland Naturalist 150:139-138.

McGee, S.G. 1980. Helminth parasites of squirrels (Sciuridae) in Saskatchewan. Canadian Journal of Zoology 58:2040-2050.

McLeod, J. A. 1933. A parasitological survey of the genus Citellus in Manitoba. Canadian Journal of Research 9:108-127.

McInvaille, W.B., Jr., and L B. Keith. 1974. Predator-prey relations and breeding biology of the great horned owl and red-tailed hawk in central Alberta. Canadian Field-Naturalist 88:1-20. 
Meslow, E.C., and L.B. Keith. 1966. Summer food habits of red-tailed hawks near Rochester, Alberta. Canadian Field-Naturalist 80:98-100.

Michener, G.R. 1984. Age, sex, and species differences in the annual cycles of grounddwelling Sciurids: implications for sociality. Pages 81-107 in J.O. Murie and G.R. Michener, eds. The biology of ground-dwelling squirrels. University of Nebraska Press, Lincoln. 459 pp.

Mohr, C.O. 1943. Distribution of ground squirrels in Illinois. Transactions of the Illinois State Academy of Sciences 36:177-178.

Mumford, R.E. 1969. Distribution of the mammals of Indiana. Monograph of the Indiana Academy of Science 1:1-114.

Mumford, R.E., and J.O. Whitaker, Jr. 1982. Mammals of Indiana. Indiana University Press, Bloomington. 537 pp.

Murie, J.O. 1973. Population characteristics and phenology of a Franklin ground squirrel (Spermophilus franklinii) colony in Alberta, Canada. American Midland Naturalist 90:334340.

Murie, J.O. 1999. Franklin's ground squirrel, Spermophilus franklinii. Pages 419-420 in D.E. Wilson and S. Ruff, eds. The Smithsonian book of North American mammals. Smithsonian Institution Press, Washington. 750 pp.

NatureServe. 2004. NatureServe Explorer: An online encyclopedia of life [web application]. Version 4.1. NatureServe, Arlington, Virginia. Available http://www.natureserve.org/explorer. (Accessed: January 4, 2005).

Orr, H.D. 1958. Orientation of the Franklin ground squirrel to environmental objects. The Minnesota Academy of Science 15,16:225-232.

Over, W.H., and E.P. Churchill. 1945. Mammals of South Dakota. The Museum, University of South Dakota, Vermillion. 56 pp.
Panzer, R., and M. Schipp. 1986. Franklin's ground squirrel translocated to an Illinois prairie preserve. Restoration and Management Notes 4:27.

Pergams, O.R.W., and D. Nyberg. 2001. Museum collections of mammals corroborate the exceptional decline of prairie habitat in the Chicago region. Journal of Mammalogy 82:984-992.

Pergams, O., and D. Nyberg. 2003. Spermophilus franklinii in: IUCN 2004. 2004 IUCN Red List of Threatened Species. <www.redlist. org $>$. Downloaded on 04 January 2005.

Peterson, R.L. 1966. The mammals of eastern Canada. Oxford University Press, Toronto. $465 \mathrm{pp}$.

Pivorun, E.B., and W.B. Sinnamon. 1981. Blood coagulation studies in normothermic, hibernating, and aroused Spermophilus franklinii. Cryobiology 18:515-520.

Platt, D.R, F.B. Cross, D. Distler, O.S. Fent, E.R. Hall, M. Terman, J. Walstrom, and J. Zimmerman. 1973. Rare, endangered and extirpated species in Kansas. III. Mammals. Transactions of the Kansas Academy of Science 76:267-272.

Polder, E. 1965. Vertebrate coactions with the Franklin ground squirrel. Iowa Academy of Science 72:202-206.

Preble, E.A. 1908. A biological investigation of the Athabaska-Mackenzie region. North American Fauna 27:1-574.

Purdue, J.R., and B.W. Styles. 1987. Changes in the mammalian fauna of Illinois and Missouri during the late Pleistocene and Holocene. Pages 144-175 in R.W. Graham, H.A.Semken, Jr., and M.A. Graham, eds. Late Quaternary mammalian biogeography and environments of the Great Plains and prairies. Illinois State Museum, Scientific Papers, Vol. 22. Springfield. $491 \mathrm{pp}$. 
Reichardt, T.R., and T.D. Galloway. 1994. Seasonal occurrence and reproductive status of Opisocrostis bruneri (Siphonaptera: Ceratophyllidae), a flea on Franklin's ground squirrel, Spermophilus franklinii (Rodentia: Sciuridae), near Birds Hill Park, Manitoba. Journal of Medical Entomology 31:105-113.

Rhodes, R.S., II, and H.A. Semken, Jr. 1986. Quaternary biostratigraphy and paleoecology of fossil animals from the loess hills region of western Iowa. Proceedings of the Iowa Academy of Sciences 93:94-130.

Richardson, J. 1829. Fauna Boreali-americana. Volume 1, The quadrupeds. John Murray, London. 300 pp.

Robins, J.D. 1970-1971. Movement of Franklin's ground squirrel into northeastern Minnesota. The Minnesota Academy of Science 37:30-31.

Ruthven, A.G., and N.A. Wood. 1912. Notes on a collection of mammals from northwestern Iowa. Proceedings of the Iowa Academy of Science 19:203-205.

Sabine, J. 1822. Account of the marmots of North America hitherto known, with notices and descriptions of three new species. The Transactions of the Linnean Society of London 8:579-591.

Samson, F., and F. Knopf. 1994. Prairie conservation in North America. BioScience 44:418-421.

Sargeant, A.B., R.J. Greenwood, M.A. Sovada, and T.L. Shaffer. 1993. Distribution and abundance of predators that affect duck productionPrairie Pothole Region. United States Department of the Interior, Fish and Wildlife Service, Resource Publication 194. Washington, D.C. $96 \mathrm{pp}$.

Sargeant, A.B., M.A. Sovada, and R.J. Greenwood. 1987. Responses of three prairie ground squirrels species, Spermophilus franklinii, $S$. richardsonii, and $S$. tridecemlineatus, to duck eggs. Canadian Field-Naturalist 101:95-97.
Schmidt, F.J. 1931. Mammals of western Clark County, Wisconsin. Journal of Mammalogy 12:99-117.

Schwartz, C.W., and E.R. Schwartz. 1981. The wild mammals of Missouri. Revised edition. University of Missouri Press and Missouri Department of Conservation, Columbia. 356 pp.

Scott, T.G. 1937. Mammals of Iowa. Iowa State College Journal of Science 12:43-97.

Scott, T.G., Y.L. Willis, and J.A. Ellis. 1959. Some effects of a field application of dieldrin on wildlife. Journal of Wildlife Management 23:409-427.

Semken, H.A. Jr., and C.R. Falk. 1987. Late Pleistocene/Holocene mammalian faunas and environmental changes on the northern plains of the United States. Pages 176-313 in R.W. Graham, H.A. Semken, Jr., and M.A. Graham, eds. Late Quaternary mammalian biogeography and environments of the Great Plains and prairies. Illinois State Museum, Scientific Papers, Vol. 22. Springfield. 491 pp.

Seton, E.T. 1910. Life histories of northern animals: an account of the mammals of Manitoba. Vol. 1, Grass-eaters. Constable and Co., Ltd. London, 676 pp.

Skarpe, C. 1992. Dynamics of savanna ecosystems. Journal of Vegetation Science 3:293-300.

Slaughter, B.H., and B.R. Hoover. 1963. Sulphur river formation and the Pleistocene mammals of the Ben Franklin local fauna. Journal of the Graduate Research Center 31:132-148.

Smith, H.C. 1993. Alberta mammals: an atlas and guide. The Provincial Museum of Alberta, Edmonton. 250 pp.

Snead, E., and G.O. Hendrickson. 1942. Food habits of the badger in Iowa. Journal of Mammalogy 23:380-391. 
Snyder, L.L. 1938. A faunal investigation of western Rainy River District, Ontario. Contributions of the Royal Ontario Museum of Zoology 14:157-213.

Snyder, W.E. 1902. A list, with brief notes, of the mammals of Dodge Co., Wis. Bulletin of the Wisconsin Natural History Society 2:113-126.

Soper, J.D. 1921. Gleanings from the Canadian west. Part II. Mammalian fauna of Islay, Alberta. Canadian Field-Naturalist 35:102114.

Soper, J.D. 1946. Mammals of the northern Great Plains along the international boundary in Canada. Journal of Mammalogy 27:127-153.

Soper, J.D. 1951. The mammals of Prince Albert National Park, Saskatchewan, Canada. Wildlife Management Bulletin Series 1, Number 5, Ottawa. $48 \mathrm{pp}$.

Soper, J.D. 1953. The mammals of Riding Mountain National Park, Manitoba, Canada. Wildlife Management Bulletin, Series 1, Number 7, Ottawa. 34 pp.

Soper, J.D. 1961a. The mammals of Manitoba. Canadian Field-Naturalist 75:171-219.

Soper, J. D. 1961b. Field data on the mammals of southern Saskatchewan. Canadian Field-Naturalist 75:23-41.

Soper, J.D. 1964. The mammals of Alberta. Department of Industry and Development, Edmonton. 410 pp.

Sowls, L.K. 1948. The Franklin ground squirrel, Citellus franklinii (Sabine), and its relationship to nesting ducks. Journal of Mammalogy 29:113-137.

Spurrell, J.A. 1917. An annotated list of the mammals of Sac County, Iowa. Proceedings of the Iowa Academy of Science 24:273-284.
Stoner, D. 1918. The rodents of Iowa. Iowa Geological Survey Bulletin 5:1-172.

Strong, M. 1883. List of the mammals of Wisconsin. Pages 436-440 in Geology of Wisconsin, Survey of 1873-1879. Volume I. David Atwood, Madison and Seifert, Gügler and Co., Milwaukee. 725 pp.

Swanson, G., T. Surber, and T.S. Roberts. 1945. The mammals of Minnesota. Technical Bulletin Number 2, Minnesota Department of Conservation. $108 \mathrm{pp}$.

Swenk, M.H. 1908. A preliminary review of the mammals of Nebraska. Studies from the Zoological Laboratory, The University of Nebraska 89:1-88.

Taft, J.B. 1997. Savanna and open-woodland communities. Pages 24-54 in M.W. Schwartz, ed. Conservation in highly fragmented landscapes. Chapman and Hall, New York. 436 pp.

Tamsitt, J.R. 1962. Mammals of the Delta Marsh Region of Lake Manitoba, Canada. Canadian Field-Naturalist 76:71-78.

Tobon, J.L., T.M. Yuill, and W.M. Samuel. 1976. Adiaspiromycosis in the Franklin's ground squirrel, Spermophilus franklinii, and pika, Ochotona princeps, from Alberta, Canada. Journal of Wildlife Diseases 12:97-100.

Van Hyning, T., and F.C. Pellett. 1910. An annotated catalogue of the recent mammals of Iowa. Proceedings of the Iowa Academy of Science 211-218.

Van Petten, A., and P. Schramm. 1972. Introduction, dispersal, and population increase of the Franklin's ground squirrel, Spermophilus franklinii, in a restored prairie. Pages 166-173 in J.H. Zimmerman, ed. Proceedings of the 2nd Prairie Symposium. Madison, Wisconsin. $242 \mathrm{pp}$. 
Wade, O. 1930. The behavior of certain spermophiles with special reference to aestivation and hibernation. Journal of Mammalogy 11:160-188.

Wade, O. 1948. Rapid fat production by ground squirrels preceding hibernation. Natural History Miscellanea, Chicago Academy of Sciences. 28:1-3.

Wade, O. 1950. Soil temperatures, weather conditions, and emergence of ground squirrels from hibernation. Journal of Mammalogy 31:158-161.

Wade, O., and P.T. Gilbert. 1940. The baculum of some sciuridae and its significance in determining relationships. Journal of Mammalogy 21:52-63.

Warren, G.K. 1875. Preliminary report of explorations in Nebraska and Dakota, in the years 1855-56-57. Government Printing Office, Washington. $125 \mathrm{pp}$.

Wood, F.E. 1910. A study of the mammals of Champaign County, Illinois. Bulletin of the Illinois State Laboratory of Natural History 8:501-613.

Wrigley, R.E. 1974. Mammals of the sandhills of southwestern Manitoba. CanadianFieldNaturalist 88:21-39. 


\section{APPENDIX}

Given below is the list of 732 Franklin's ground squirrels, Spermophilus franklinii, examined and geographically plotted in Figure 2. Specimens are arranged by country of origin, province or state, and county - when given, all in alphabetical order. A key to museum codes (Hafner et al. 1997) follows the list of specimens.

\section{CANADA}

Alberta: Athabasca area, T66 R24 Sec. 25, 1 (UMMZ); 1 mi N, 9 mi W Athabasca, 1 (PMA); Beaverhill Lake, 3 (PMA); Belvedere, 1 (CMN); 1 1/2 mi SSW Blackfalds, 1 (MSU); Camrose, 2 (ROM); Camrose, Pelican Lake, 1 (ROM); Chain Lakes, 2 (PMA); Chain Lakes Recreation Area campground, T69N, R23W, Sec. 7, NW 1/4, 1 (UNSM); Beaver River, near Cold Lake, 1 (CMN); Driedmeat Lake, 3 (ROM); Edmonton, 3 (CMN); 2 (ROM); Lac la Nonne, 4 (CMN); Battle River $\mathrm{S}$ of Galahad, 1 (CMN); Marwayne, 1 (CMN); near Mayerthorpe, 1 (PMA); Meanook, 1 (PMA); Meeting Creek, 1 (CMN); Morinville, 2 (PMA); Raft Lake, 1 (PMA); Red Deer, 1 (CMN); N Red Deer, Red Deer River, 1 (CMN); Red Lodge, 1 (ROM); Rochon Sands Provincial Park, 1 (PMA); 1 (UNSM); Sandy Lake, 1 (CMN); Sturgeon River, 25 mi N of Edmonton, 2 (NMNH).

Manitoba: Aweme, 2 (MMMN), 4 (ROM); Birtle, 1 (MMMN); Carberry, 1 (CMN), 3 (NMNH); 1 km N Cromer, 1 (MMMN); Dauphin, 1 (CMN); Delta, 1 (CMN), 1 (MMN), 2 (MMNH), 11 (MUMZ), 2 (NMNH), 2 (UMMZ), 1 (UWZM); Delta Marsh, 3 (MMMN); Delta Marsh, University Field Station, 8 (MMMN), 1 (UNSM); 1.5 mi W Delta, 1 (ROM); 3 mi E Delta, 1 (ROM); S of Duck Mountain Forest Reserve, 1 (CMN); 3.2 km N, 9.6 km W Dugald, 1 (MMMN); 5.8 km S, $1.6 \mathrm{~km}$ E Hadashville, 2 (MMMN); $13.5 \mathrm{~km} \mathrm{~N}, 29.6 \mathrm{~km}$ W Hodgson, vicinity of Matootoo Lake, 1 (MMMN); Huns Valley, 1 (ROM); 10 km N Libau, 2 (MMMN); Manitoba House, 1 (NMNH); 6.4 km N, 0.8 km W Margaret, 2 (MMMN); Neepawa, 2 (ROM); 13 km S, 7 km W Oak Lake, 2 (MMMN); 11.2 km S Oak Lake, 1 (MMMN); Patricia Beach, 1 (MMMN); Pinawa, Whiteshell Nuclear Research Est., 30 (MMMN); Portage la Prairie vicinity, 1 (ROM); Red Rock Lake, near Rennie, 2 (CMN); Rennie, 1 (MUMZ); Riding Mountain National Park, 1 mi S of S gate, 2 (YPM); Riding Mountain National Park, Lake Andy campground, 1 (YPM); 3.2 km N, 3.2 km E Roseisle, 2 (MMMN); Shoal Lake, 1 (CMN); 11 km N, 4 km E Sprague, 4 (MMMN); 3.2 km NW St. Ambroise, 1 (MMMN); 4.8 km N, 4.8 km W St. Ambroise, 1 (MMMN); St. Ambroise Beach, 3 (MMMN); St. Charles, 1 (ROM); Swan River, 1 (CMN); The Pas, 2 (CMN), 1 (YPM), 1 (MMMN); 4 km SW The Pas, 1 (CMN); University Field Station, 1 (MMMN); Winnipeg, 3/4 mi E on Paul Blvd, 1 (MMMN); Winnipeg, Brockville St. and Wilker Ave., 1 (CMN); Winnipeg, vicinity of Springfield sanitation land fill, 1 (MMMN); Winnipeg, Deer Lodge, 1 (ROM); Winnipeg, St. Vitae, 1 (ROM); Winnipeg, 3 (MMMN), 1 (NMNH), 2 (ROM).

Ontario: $1 \mathrm{~km}$ NE of Crozier, Crozier TSP, Fort Frances Dist., 1 (ROM); 3 km NW of Stratton, Morley TSP, Fort Frances Dist., 3 (ROM); Long Sault Rapids, Study Site 1, Roseberry TSP, Fort Frances Dist., 1 (ROM); Keewatin, Kenora Dist., 1 (ROM); Royal Lake, $25 \mathrm{mi} \mathrm{W}$ of Kenora, Kenora Dist., 1 (ROM); Rainy River, 8 (ROM); Rainy River Dist., 1 (ROM); Carpenter Twp, Rainy River Dist., 1 (ROM); N of Rainy R., Curran TSP, Rainy River Dist., 1 (ROM); 1 1/2 mi upstream from Lake of the Woods on Rainy River, 1 (ROM).

Saskatchewan: Broadview, 2 (CMN); Carlton House, 4 (NMNH); 6 mi S Dorintosh, 2 (CMN); Douglas Provincial Park, Middaugh campground, 1 (UNSM); Dundurn, 2 (ROM); Emma Lake, 2 (CM); Emma Lake, Prince Albert Dist., 2 (ROM); 3 (UMMZ); Fort Carlton, 4 (ROM); Good 
Spirit Lake Provincial Park, Aspen campground, 2 (UNSM); Indian Head, 5 (CMN); 8 (ROM); Indian Head, Assiniboia, 3 (NMNH); 1 mi W of Lebret, Qu'Appelle Vy., 1 (UMMZ); South arm, Last Mountain Lake, 1 (CMN); Moose Mountain Provincial Park, T10N, R3W, Sec. 24, SE 1/4, 1 (UNSM); Oxbow, 1 (NMNH); Prince Albert, 1 (FMNH); 7 mi S, 2 mi W Prince Albert, 46N, 27W, Sec. 36, NE 1/4, 1 (UNSM); Rokeby, 1 (ROM); Watson, 2 (ROM); Wingard, 5 (NMNH); Katepwe Lake, 2 (ROM); TWP 31, RGE 28, Sec. 6, SW 1/4, 1 (UNSM).

\section{UNITED STATES}

Illinois: Carroll Co.: Mount Carroll, 1 (NMNH); Champaign Co.: 2 1/2 mi SE Broadlands, 1 (CM); Champaign, 1 (ISUVC); 1 mi S Champaign, 1 (UIMNH); 1 mi W Champaign on Route 150, 1 (UIMNH); 3 mi S Champaign, 3 (UIMNH); $10 \mathrm{mi} \mathrm{N}$ and $2 \mathrm{mi} \mathrm{W}$ Champaign, 1 (UIMNH); Mayview, 2 (UIMNH); 4/10 mi W Mayview, 2 (UIMNH); 1.2 mi E Mayview, 1 (UIMNH); 1 1/2 mi E Mayview, 1 (UIMNH); 2 mi E of Mayview, 3 (UIMNH); Mayview Cemetery, 1 (UIMNH); Vic. Parkland College, 1 (UIMNH); 1.2 mi W Saint Joseph, 4 (UIMNH); 1 1/2 mi W Saint Joseph, 1 (UIMNH); Saint Mary's Cemetery, 1 1/2 mi S Champaign, 1 (UIMNH); 2 mi S Savoy, 1 (UIMNH); Seymour, 1 (UIMNH); Urbana, 4 (INHS); E of Urbana, 1 (INHS); Urbana township, 1 (UIMNH); Willard Airport, 1 (UIMNH); Christian Co.: 1/2 mi E Stonington, 1 (UIMNH); Coles Co.: Vic. Mattoon, 1 (UIMNH); Cook Co.: Chicago, 1 (CHAS), 1 (YPM); Chicago Heights, 1 (FMNH); Lemont, 1 (CHAS); West Northfield, 2 (NMNH), 1 (UMMZ); Western Springs, 49th and Fair Elms Ave., 1 (MSB); DuPage Co.: Glen Ellyn, 1 (CHAS); Milton Twp, 3 (CHAS); Fulton Co.: 3 mi W Canton, 1 (UIMNH); 4 mi NW Canton, 1 (UIMNH); 1 mi NW Norris, 2 (UIMNH); Hancock Co.: Warsaw, 1 (FMNH), 3 (NMNH); Kane Co.: 3 mi W Geneva, 1 (FMNH); Lake Co.: Fox Lake, 1 (FMNH); Grays Lake, 7 (CHAS); $1.6 \mathrm{mi} \mathrm{N}$ of Mundelein on city limits on Hwy 45, 1 (FMNH); LaSalle Co.: Earlville, 1 (INHS); Livingston Co.: 1 mi S Strawn, 1 (UIMNH); McLean Co.: $1 \mathrm{mi} \mathrm{S}$ of Route 9, $1 \mathrm{mi} \mathrm{W}$ of Bloomington city limits, 1 (ISU); $4 \mathrm{mi}$ SW of Bloomington city limits on Gulf Mobile and Ohio R. R., 1 (ISU); 6 mi NE Normal, 1 (ISU); 7.5 mi NE Normal, 3 (ISU); Ogle Co.: Oregon, 1 (INHS); Piatt Co.: 1 mi N Monticello (highway), 1 (UIMNH); Vermillion Co.: 10 mi W Danville, 1 (UIMNH); Will Co.: Joliet, 1 (UMMZ); near Lemont (in Cook County), 1 (CHAS).

Indiana: Benton Co.: $1 \mathrm{mi} \mathrm{S}$ of Atkinson, 1 (NMNH); Fulton Co.: $3 \mathrm{mi} \mathrm{W,} 1 \mathrm{mi} \mathrm{N}$ Rochester, 1 (NMNH); Jasper Co.: 6 mi N, 10 mi E Rensselaer, 1 (NMNH); Lake Co.: Miller, 2 (FMNH); LaPorte Co.: At interchange of Indiana toll road and U. S. 421, 1 (NMNH); Marshall Co.: Tyner, 1 (NMNH); Newton Co.: Lake Village, 6 (UMMZ); Morocco, 2 (ISUVC); Mount Ayr, 3 (NMNH); Porter Co.: Dune Acres, 1 (CHAS); Dunes State Park, 1 (JMM); St. Joseph Co.: 3 mi S of North Liberty, 1 (ISUVC); 2 1/2 mi W, 1 mi S of North Liberty, 1 (NMNH); Walkerton, 1 (NMNH); Tippecanoe Co.: Klondike, 1 (JMM); 1 1/2 mi S of Romney, 1 (NMNH); Wabbash Township, 1 (NMNH); White Co.: Shafer Lake, 2 (UMMZ).

Iowa: Butler Co.: T90N, R18W, Washington Township, 1 (HMNH); Clay Co.: 9 (UMMZ); Webb, 3 (AMNH); Crawford Co.: Dow City, 1 (CHAS); Des Moines Co.: Burlington, 1 (NMNH); Dickinson Co.: Milford, 1 (UMMZ); Grundy Co.: 5 mi W Grundy Center, 1 (IOWA); Jasper Co.: 1 mi N Prairie City, 1 (KU); Johnson Co.: Iowa City, 1 (AMNH); Louisa Co.: 1 (IOWA); Mahaska Co.: 1 1/2 mi S, 2 mi E New Sharon, 2 (KU); 5 mi N Oskaloosa, 1 (KU); Marion Co.: 1 1/2 mi S, 1 1/2 mi W Pella, 1 (IOWA); Mills Co.: 1 mi N, 5 mi W Malvern, 1 (BVC); Monona Co.: 2 mi N Pisgah, 1 (BVC); 1 mi N, 3 1/2 mi W Whiting, South Badger Lake, 1 (IOWA); Montgomery Co.: 11.1 mi E Red Oak, 1 (MSB); Muscatine Co.: Conesville, 1 (NMNH); Story Co.: Ames, 3 (NMNH); Franklin Township, 1 (MSU). 
Kansas: Allen Co.: 5 1/2 mi N of Moran, 1 (KU); Douglas Co.: 2 1/2 mi NW Eudora, 1 (KU); Lawrence, 3 (KU); KU campus, Lawrence, 1 (KU); 1 1/2 mi E, $13 / 4$ mi N Lawrence, 1 (KU); 2 mi S Lawrence, E. Haskel Bottoms, 1 (CMN); 2 mi N, 1.6 mi E Douglas Co. courthouse, Lawrence, 1 (KU); 2 mi E, 2 mi N Lawrence, $1(\mathrm{KU})$; near Lawrence, 2 1/2 mi S, 1/4 mi W No. 6 school house, S side of Wakarusa Creek, 1 (KU); 3 mi SW Lawrence, 1 (KU); 3 mi S Lawrence, 1 (KU); 3 mi N Lawrence, 1 (KU); 3 1/2 mi S Lawrence, 1 (KU); 4 mi N of Lawrence, between Teepee junction and R. R. tracks, 2 (KU); 7 1/2 mi SW Lawrence, 1 (KU); Greenwood Co.: Hamilton, 1 (KU); Jewell Co.: 20 mi E Smith Center, 1 (KU); T15, R7W, Sec. 14, NW 1/4, 3 (MHP); McPherson Co.: Smokey Hill River, $1 \mathrm{mi} \mathrm{S}, 1 / 2 \mathrm{mi} W$ Lindsborg, 2 (KU); 1/2 mi E McPherson, 4 (KU); Mitchell Co.: 3 1/2 mi W, 1/2 mi S Beloit, 1 (KU); Phillips Co.: 1 1/2 mi W Glade, T4S, R18W, Sec. 22, SW 1/4, 1 (MHP); 1 mi N, 6 1/4 mi W Kirwin, T4S, R17W, Sec. 21, S 1/2, 1 (MHP); 1 3/4 mi S, 4 mi W Kirwin, T5S, R17W, Sec. 1, SW 1/4, 1 (MHP); 10.8 mi N Phillipsburg, 1 (MHP); Pottawatomie Co.: 3 mi NW of St. Mary's, 1 (KU); Onaga, 1 (NMNH); Republic Co.: Agenda, 1 (KU); Riley Co.: Manhattan, 1 (KU); Woodson Co.: Neosho Falls, 3 (KU).

Minnesota: Beltrami Co.: 1/4 mi NE Redby, 4 (MMNH); Big Stone Co.: Big Stone Lake State Park, T122N, R47W, Sec. 10, SE 1/4 of SE 1/4, 1 (MMNH); Ortonville, 11 (NMNH); Ortonville, Elk River, 1 (CMN); Blue Earth Co.: 3 mi S Minnesota Lake, 1 (SHMC); Rapidan, 1 (INHS); Cass Co.: Cass Lake, 2 (NMNH); 2 mi SE Winnie Dam, T145N, R27W, Sec. 35, E 1/2, Chippewa Forest, 1 (MMNH); Clay Co.: 1 1/2 mi W Buffalo River State Park, 1 (UIMNH); Moorhead (Bosshard Farm), 1 (CM); T141N, R46W, Sec. 24, NW 1/4, 1 (MMNH); Clearwater Co.: W of Itasca Park, 1 (MMNH); Biological Station, Itasca Park, garbage pile, 1 (MMNH); Itasca State Park, 1 (JMM); Grant Co.: 3 mi NW of Barrett, 1 (UMMZ); 4 mi NW of Barrett, 1 (UMMZ); Setan WPA, T130N, R43W, Sec. 25, NE 1/4, 1 (UNSM); Stony Brook Township, T130N, R43W, Sec. 24, 1 (UNSM); Hennepin Co.: Ft. Snelling, 1 (FMNH), 4 (NMNH); Hubbard Co.: Lake Alice Store, T143N, R35W, Sec. 22, NE 1/4 of SW 1/4, 5 (MMNH); Isanti Co.: 5 mi E of Hwy 65 along Cty Rd. 12, T34N, R22W, Sec. 18, 1 (MMNH); Kandiyohi Co., T121N, R35W, Sec. 27, NW 1/4, 1 (MMNH); Lac Qui Parle Co.: 1 mi N, 9 mi E Bellingham, T119N, R43W, Sec. 6, NW 1/4 of NW 1/4, 1 (MMNH); Madison, 2 (MCZ); Lake of the Woods Co.: Williams, 1 (KU), 2 (MMNH); LeSuer Co.: T112N, R24W, Sec. 23, 1 (MMNH); Mahnomen Co.: 8 mi E Mahnomen, 1 (UMMZ); Marshall Co.: Holt, 1 (MMNH); Morrison Co.: Cushing, 2 (MSB); Ottertail Co.: Fergus Falls, east of town, 2 (MMNH); Lake Lizzie, 1 (CM); Pine Co.: Bruno, 1 (MMNH); Polk Co.: $3 \mathrm{mi} \mathrm{S}, 7 \mathrm{mi}$ E of Crookston, T149N, R45W, Sec. 17, Pankratz Prairie, 2 (MMNH); Pope Co.: $7 \mathrm{mi} \mathrm{S}$ of Glenwood, 1 (MMNH); Rice Co.: Northfield, 1 (MMNH); Shieldsville Twp., Sec. 12, 1 (MMNH); Roseau Co.: Warroad, 1 (MMNH); Sherburne Co.: Elk River, 11 (NMNH), 2 (ROM), 1 (UMMZ), 1 (UWZM); Sibley Co.; $1 \mathrm{mi} \mathrm{N}$ of Gibbon, 1 (MMNH); St. Louis Co.: 1/4 mi E Adolph, 1 (MHP); 8 mi S, 1 mi W Hoyt Lakes, T57N, R14W, Sec. 19, SE 1/4, 1 (MMNH); Saginaw, 3 (KU); Traverse Co., Brown's Valley, 3 (MMNH); near Brown's Valley, 5 (NMNH); 6 mi W of Wheaton, 1 (MMNH); Wadena Co.: T134N, R35W, Sec. 8, NE 1/4, 1 (MMNH); Wilkin Co.: 3 mi S of Rothsay, 1 (MMNH); Wright Co.: Maple Lake, $1(\mathrm{MMNH})$.

Missouri: Adair Co.: 1 mi N LaPlata, 1 (NEMSU); 2 mi SE Millard, 1 (CM), 2 (NEMSU); Buchanan Co.: St. Joseph, 1 (MUMZ); 1 mi E St. Joseph, 2 (MUMZ); Caldwell Co.: Hamilton, 1 (MUMZ); Chariton Co.: Swan Lake National Wildlife Refuge, along railroad dump, 2 (MUMZ); Clark Co.: 3 mi W, 2 mi S Alexandria, 2 (NEMSU); 1 mi E Medill, 1 (NEMSU); Clinton Co.: Trimble Wildlife Area, 2 (MUMZ); Knox Co.: 3 mi SE Knox City (Hwy 6), 1 (NEMSU); Lafayette Co.: Wellington, 1 (MUMZ); Macon Co.: 4 mi N Macon, 2 (CM); 4 mi N Macon, 1 (NEM$\mathrm{SU}) ; 8 \mathrm{mi} \mathrm{N}$ Macon, 1 (CM). 
Nebraska: Antelope Co.: Neligh, 1 (UNSM); 1/4 mi N, 1/2 mi W Oakdale, 1 (UMMZ); Boone Co.: Albion, west road of fairgrounds, 1 (MHP); near Albion, 1 (MHP); 1/2 mi W, 1/2 mi S of Albion, 1 (MHP); 6 mi E of Albion, 1 (MHP); Buffalo Co.: Kearney, 1 (NMNH); Custer Co.: 1 mi S Gavin, 1 (UMMZ); Dawson Co.: E of Gothenburg, 1 (UNSM); Dodge Co.: Ames, 1 (NMNH); Douglas Co.: Omaha, 1 (YPM); Omaha, 108th and E St. intersection, 2 (MSB); Omaha, Henry Doorly Zoo, 3 (UNSM); Stolley Prairie, T15N, R11E, Sec. 15, NW 1/4, 3 (UNSM); Garfield Co.: $3 \mathrm{mi} \mathrm{N}, 4$ 1/2 mi W Burwell, 1 (VMKSC); Harlan Co.: $1 \mathrm{mi} \mathrm{S}, 0.5 \mathrm{mi}$ E of Orleans, 1 (VMKSC); Hitchcock Co.: 6 mi E of Palisade, 1 (VMKSC); Hooker Co.: Kelso, 8 (UMMZ); Knox Co.: Niobrara, 1 (NMNH); Verdigre, 1 (NMNH); Lancaster Co.: Lincoln, 1 (MVZ); Lincoln, Capital Beach Lake, 1 (NMNH); Lincoln, Mopak bike trail, T10N, R7E, Sec. 26, NW 1/4, 2 (UNSM); Lincoln Co.: North Platte, 1 (MSB); Nemaha Co.: 1/2 mi N, 1 mi E Peru, 1 (MHP); Platte Co.: Columbus, 2 (NMNH); Red Willow Co.: 2.4 mi W Cambridge, 1 (VMKSC); Richardson Co.: Falls City, 1 (KU); 3 mi S Rulo, 1 (KU); Sarpy Co.: Chalco Hills Recreation Area, T14N, R11E, Sec. 23, SW 1/4, 1 (UNSM); Thurston Co.: 1 mi S Winnebago, 1 (KU); Webster Co.: Red Cloud, 1 (UNSM).

North Dakota: Barnes Co.: Kathryn, 1 (NMNH); Benson Co.: Minnewaukan, 1 (FMNH), 1 (UWZM); Burke Co.: Lostwood National Wildlife Refuge headquarters, T160N, R91W, Sec. 35, NW 1/4, 3 (UNSM); Cass Co.: Fargo, 1 (NMNH); Harwood, 2 (NMNH); Dickey Co.: Oakes, 3 (FMNH), 3 (NMNH); Foster Co.: Bordulac, 2 (UWZM); Grand Forks Co.: 3 mi E of Emerado, 2 (MMNH); Grand Forks, 1 (NMNH); 4 (ROM); Larimore, 2 (NMNH); Kidder Co.: 1/2 mi N Pettibone, 1 (UMMZ); LaMoure Co.: LaMoure, 1 (NMNH); Nelson Co.: Stump Lake, 2 (NMNH); Pembina Co.: Pembina, 12 (NMNH), 1 (YPM); Walhalla, 2 (NMNH); Ramsey Co.: Devil's Lake, 3 (UMMZ); Richland Co.: 5 mi NE Fairmount, near Sioux River, 13 (NMNH); Rolette Co.: 1 mi N Dunseith, 1 (MVZ); 5 mi E Dunseith, 1 (MVZ); 7 mi NE Dunseith, 2 (MVZ); Turtle Mountains, Lake Upsilon, 2 (UMMZ); Sargent Co.: Tewaukon National Wildlife Refuge, 12 (UNSM); Stutsman Co.: Arrowwood National Wildlife Refuge, T143N, R63W, Sec. 6, NW 1/4, 1 (UNSM); 3 mi NW Buchanan, 1 (UCM); James River, 10 mi S Jamestown, 5 (UCM); Walsh Co.: Grafton, 2 (UNSM); Ward Co.: Baden, 1 (MSB), 1 (KU).

South Dakota: Bon Homme Co.: Scotland, 1 (NMNH); Brown Co.: 2 mi N, 3 mi W of Houghton, 2 (KU); Clay Co.: 6 1/2 mi N, 1 1/2 mi W Vermillion, 1 (MSB); Day Co.: 1 (MSU); Waubay National Wildlife Refuge, 3 (UIMNH); Webster, 3 (CHAS); Marshall Co.: Fort Sisseton, 5 (NMNH); Roy Lake State Park, 5 (KU); Moody Co.: Flandreau, 1 (NMNH); Roberts Co.: 4 mi S of Blackmer (in North Dakota), 4 (NMNH); Trip Co.: Dog Ear Lake, 1 (UMMZ); 5 mi SE Colome, 1 (UMMZ); Union Co.: 4 1/2 mi NW Jefferson, 1 (MSB).

Wisconsin: Columbia Co.: Portage, 1 (UWZM); Dane Co.: Madison, University of Wisconsin Arboretum, 2 (UWZM); Dodge Co., Beaver Dam, 6 (UWZM); Portage Co., 2 mi S Junction City, 1 (UWSP); T23N, R7E, Sec. 2, N 1/2 of SE 1/4, 1 (UWSP); 1 mi W Hwy N, 1 (UWSP); Racine Co., Racine, 1 (NMNH); Rock Co., Milton, 1 (UWZM); Walworth Co., Delavan, 2 (CHAS); 4 (NMNH); Lane's Mill, 5 (AMNH); Waukesha Co., T6N, R19E, Sec. 14, NW 1/4 of SW 1/4, 1 (MMNH); Wood Co., 3/4 mi SE Arpin, 1 (UWSP).

Museum Key: American Museum of Natural History (AMNH); Buena Vista College (BVC); Canadian Museum of Nature (CMN); Carnegie Museum of Natural History (CM); Chicago Academy of Sciences (CHAS); Earlham College, Joseph Moore Museum (JMM); Fort Hays State University, Sternberg Museum of Natural History (MHP); Harvard University, Museum of Comparative Zoology (MCZ); Illinois Natural History Survey (INHS); Illinois State University (ISU); Indiana 
State University (ISUVC); Kearney State University, Vertebrate Museum (VMKSC); Luther College, Sherman A. Hoslett Museum of Natural History (HMNH); Manitoba Museum of Man and Nature (MMMN); Michigan State University Museum (MSU); Provincial Museum of Alberta (PMA); Royal Ontario Museum (ROM); The Field Museum (FMNH); Truman State University (NEMSU); United States National Museum of Natural History (USNM); University of California, Berkeley, Museum of Vertebrate Zoology (MVZ); University of Colorado Museum (UCM); University of Illinois, Museum of Natural History (UIMNH); University of Iowa, Museum of Natural History (IOWA); University of Kansas, Museum of Natural History (KU); University of Michigan, Museum of Zoology (UMMZ); University of Minnesota, James Ford Bell Museum of Natural History (MMNH); University of Missouri, Museum of Zoology (MUMZ); University of Nebraska State Museum (UNSM); University of New Mexico, Museum of Southwestern Biology (MSB); University of Wisconsin, Stevens Point, Museum of Natural History (UWSP); University of Wisconsin, Zoological Museum (UWZM); Yale University, Peabody Museum of Natural History (YPM). 


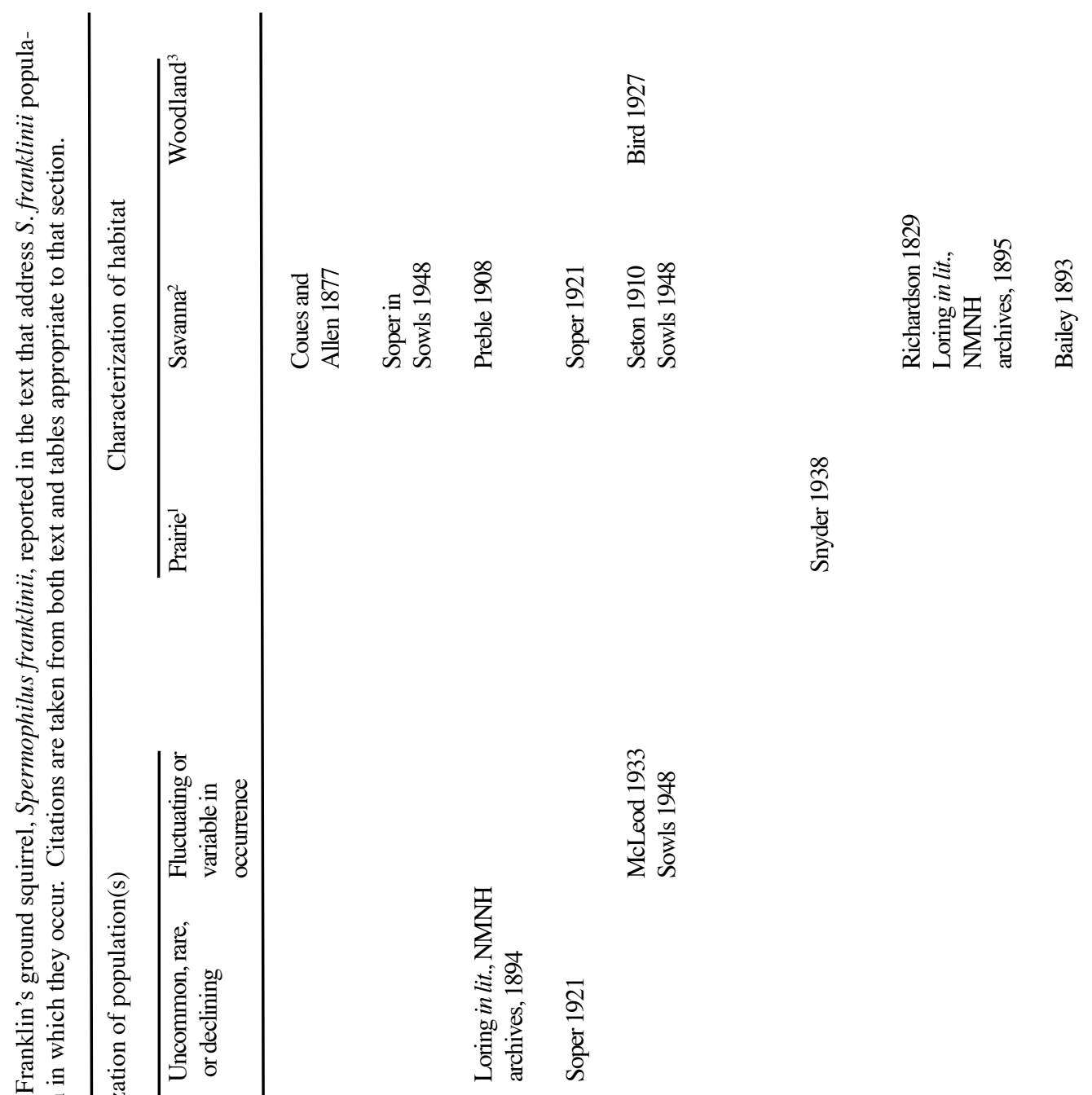

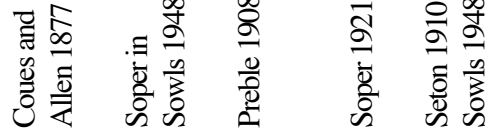




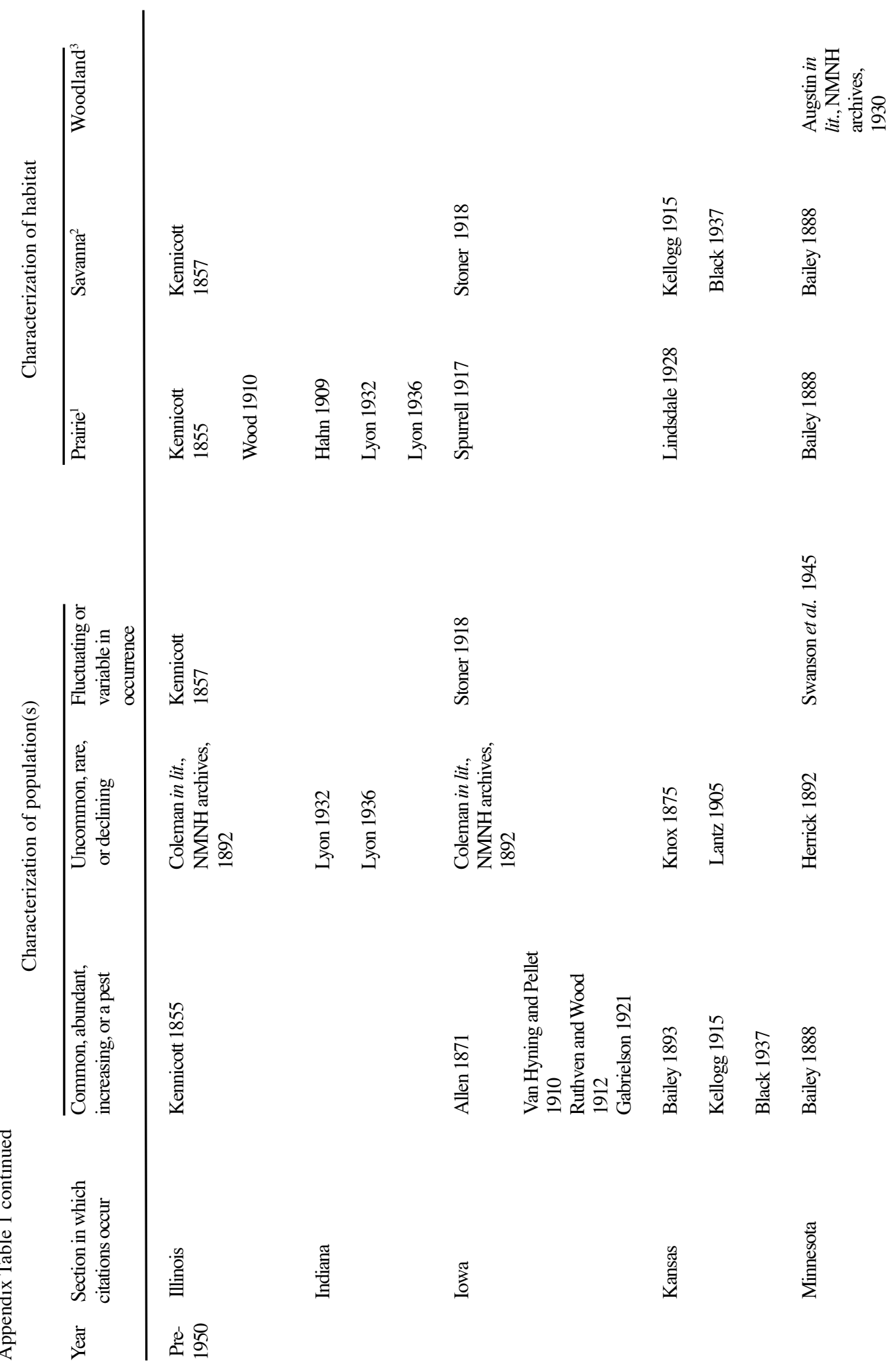




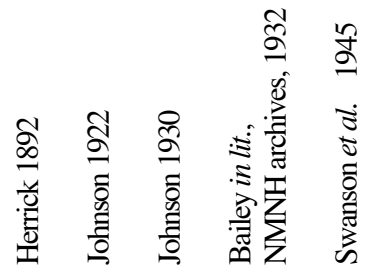
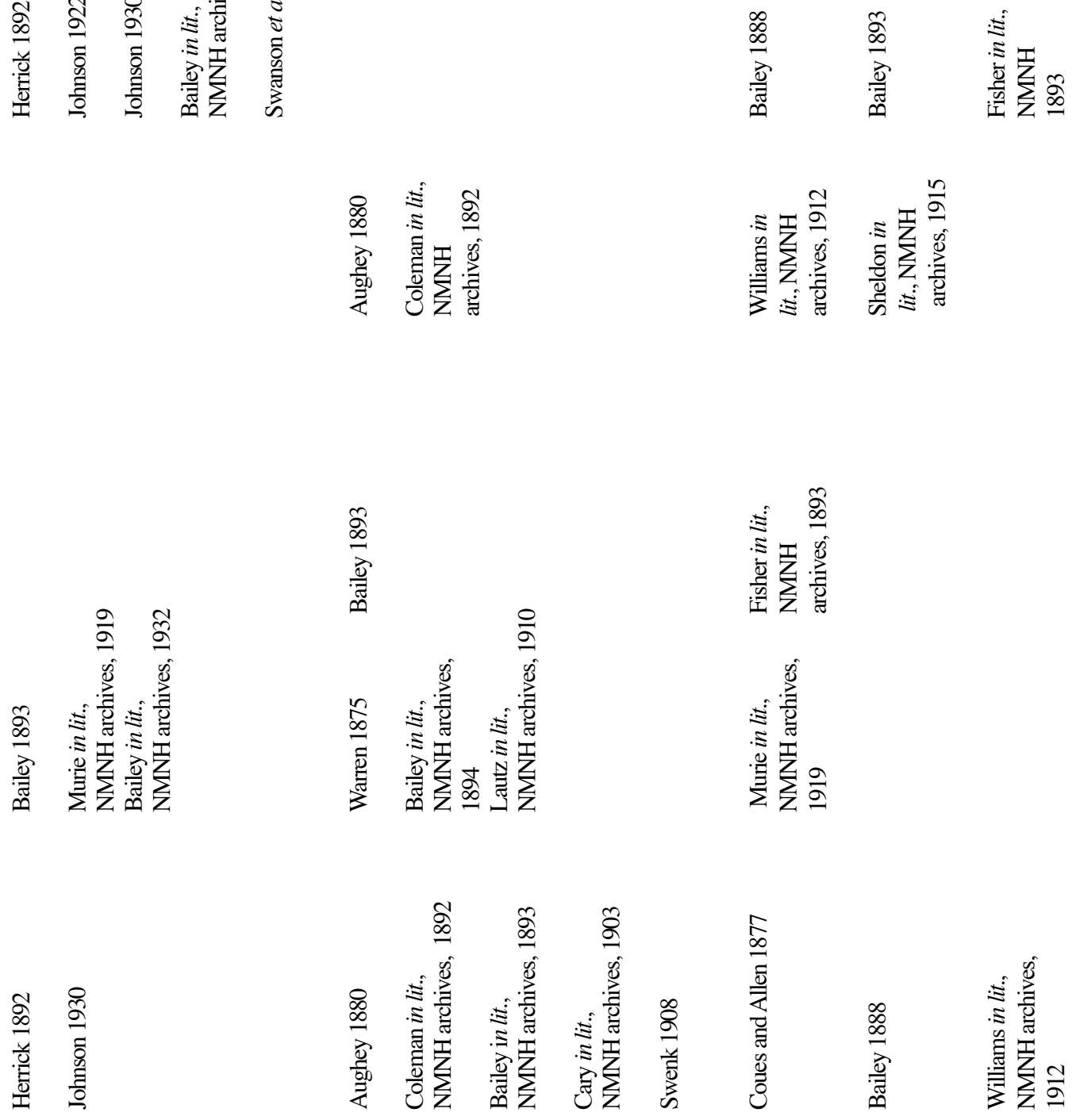

$\frac{\pi}{\tilde{0}}$

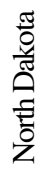




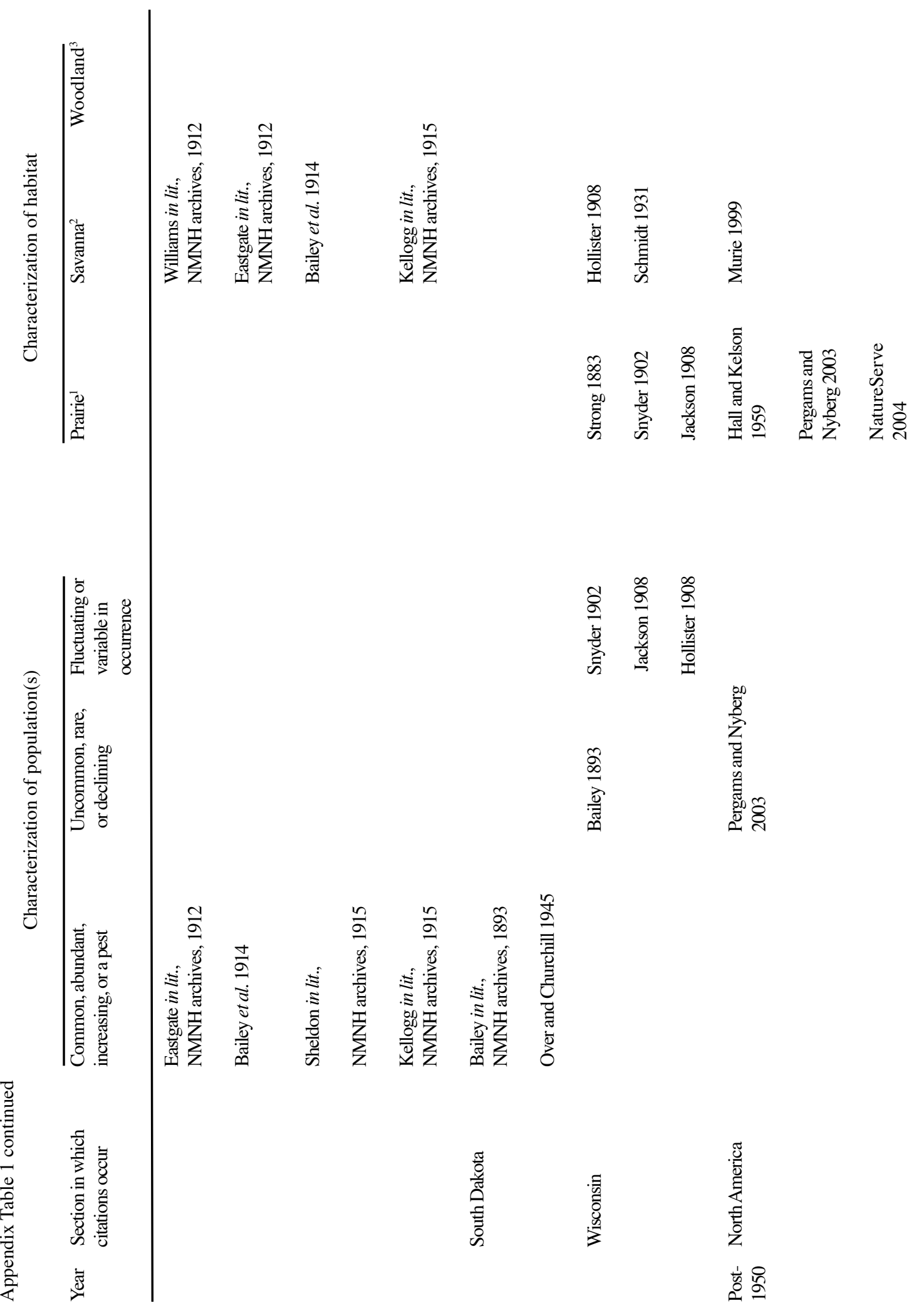



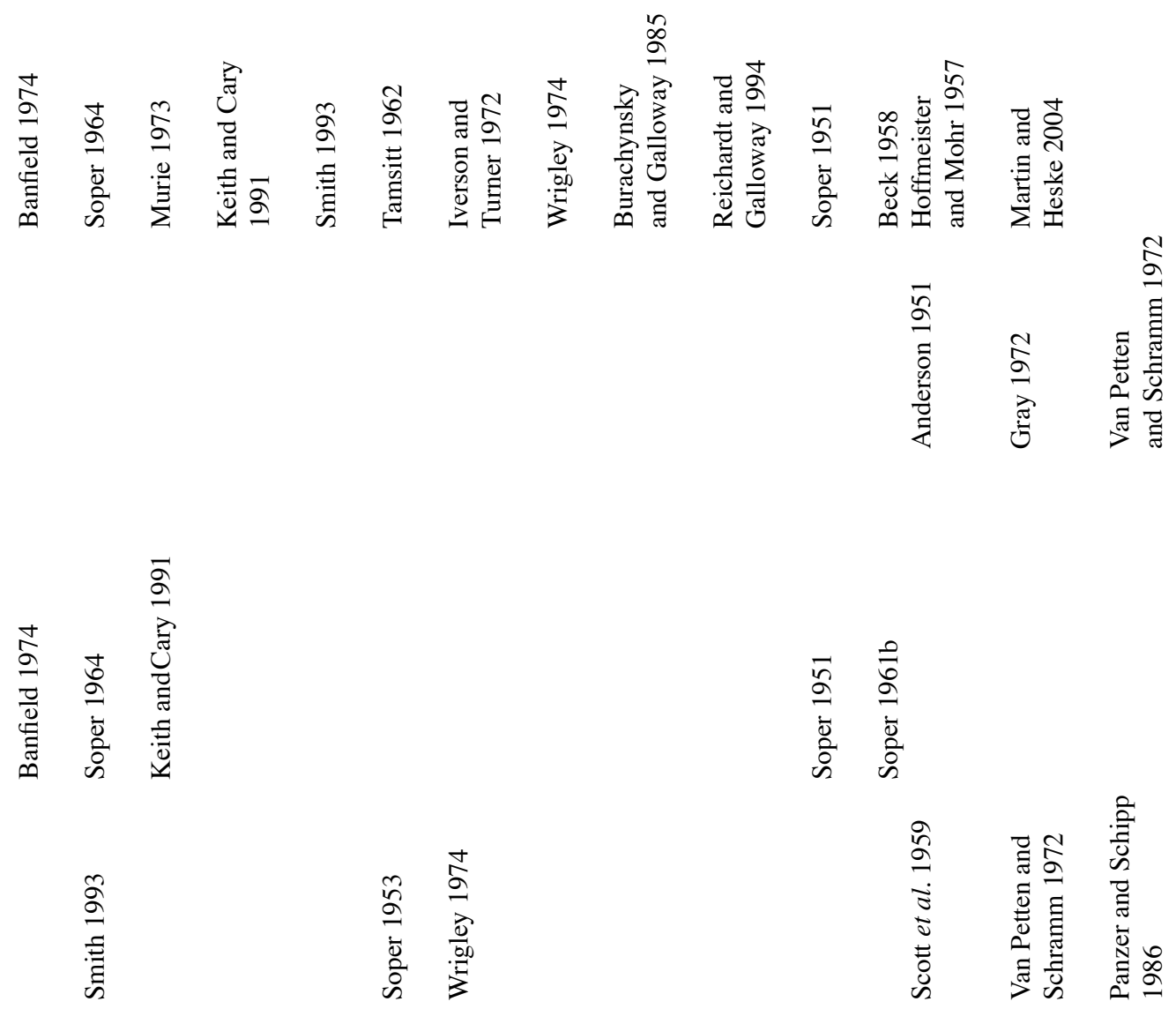

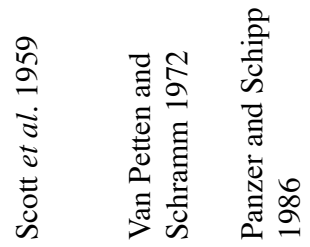
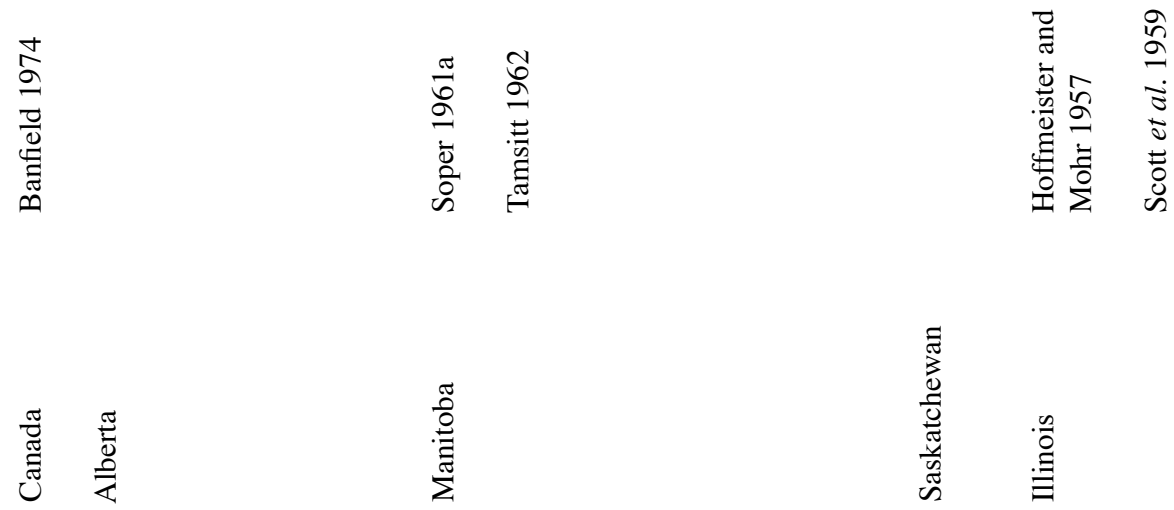

$\frac{\pi}{0} \cdot \stackrel{0}{.}$

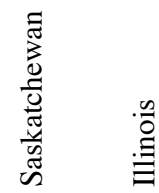




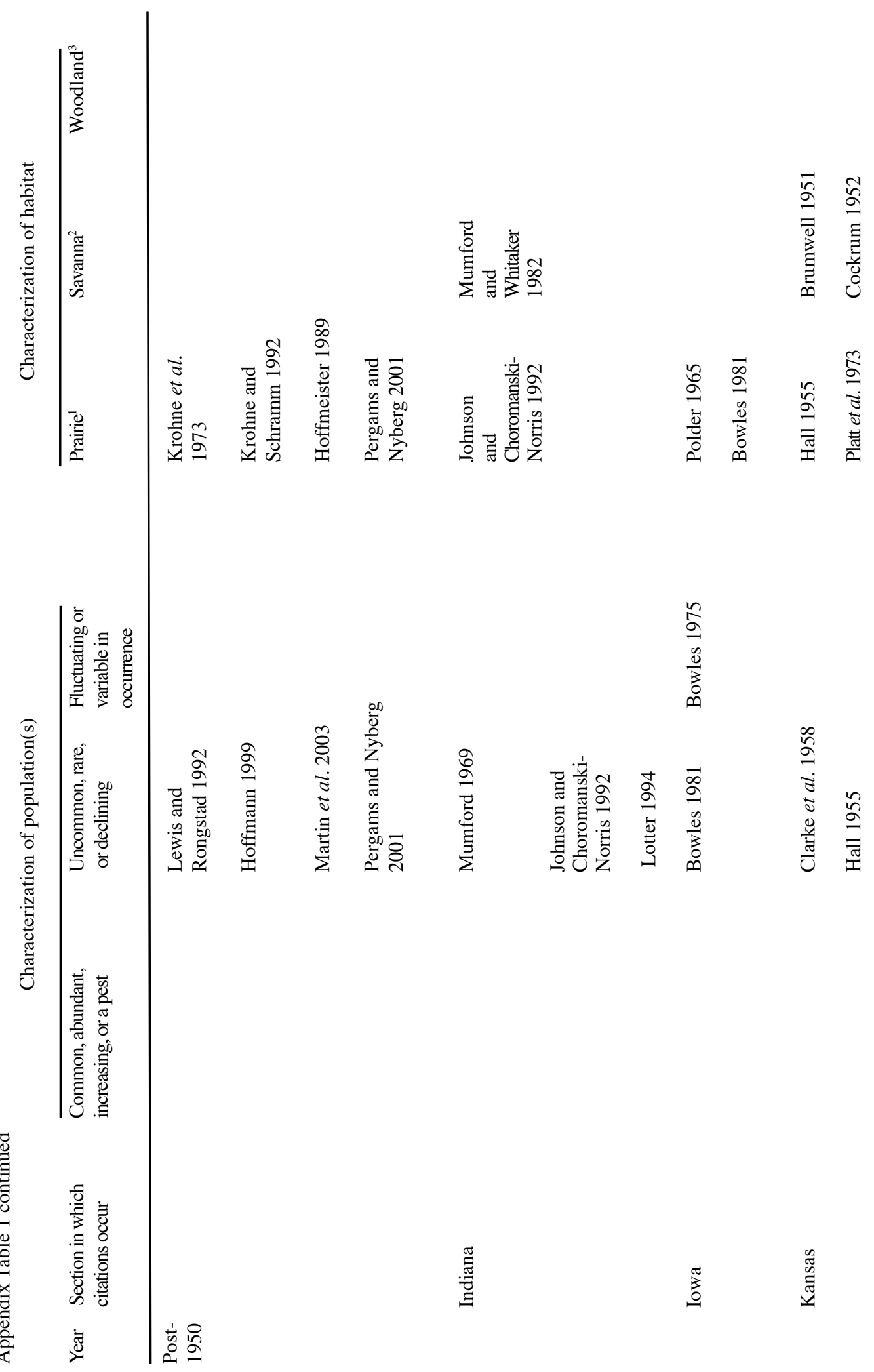




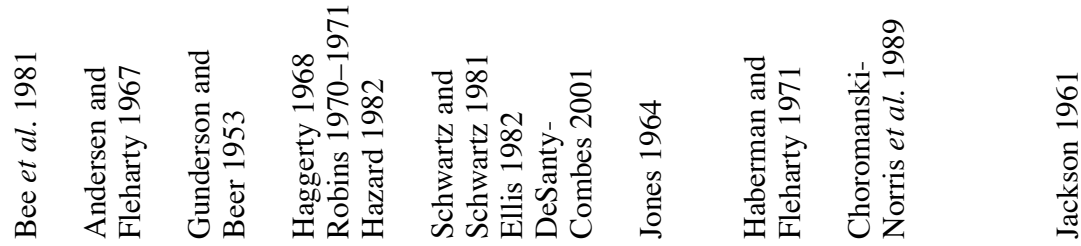

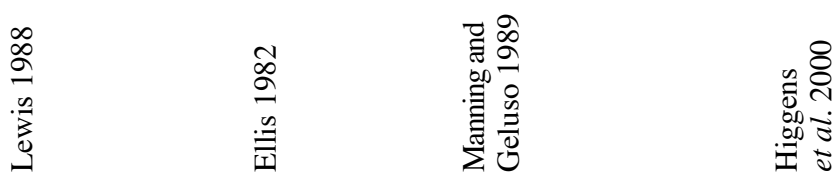

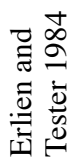
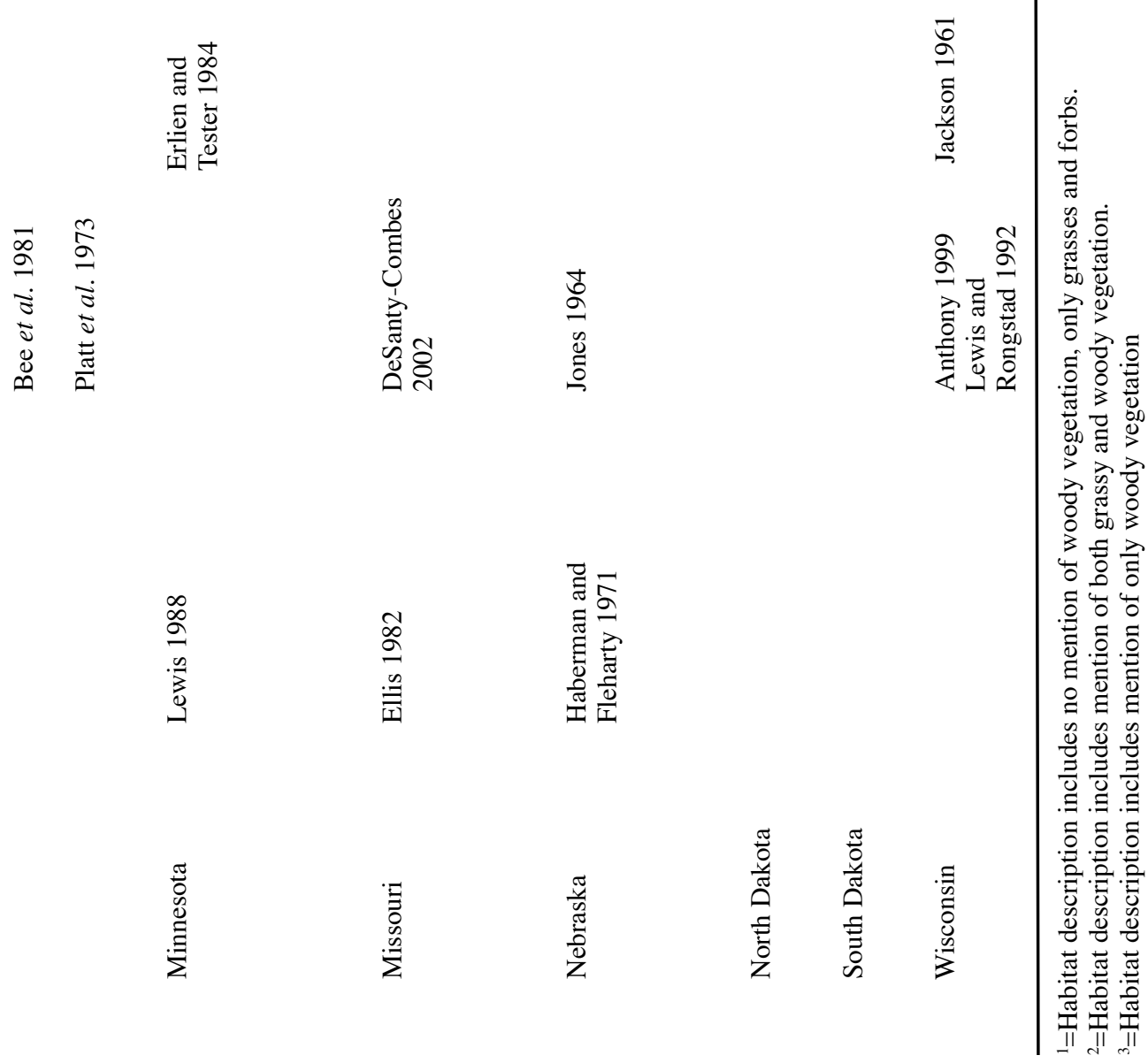


Illinois Natural History Survey

I-Building

1816 South Oak Street

Champaign, Illinois 61820

217-333-6880

A Division of the Illinois Department of Natural Resources

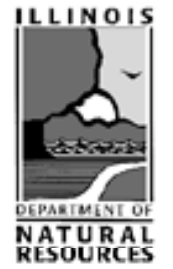

